\title{
Phosphorus and calcium requirements of growing pigs and sows
}

\author{
P. Bikker \\ M.C. Blok \\ Wageningen Livestock Research, Dept. Animal Nutrition \\ P.O. Box 338 \\ 6700 AH Wageningen \\ The Netherlands
}

CVB Documentation Report nr. 59

September 2017 


\section{(c) Federatie Nederlandse Diervoederketen 2017}

No part of this edition may be copied, photocopied, reproduced, translated or reduced to any electronic medium or machine-readable form, in whole or in part, without specific written permission of the Federatie Nederlandse Diervoederketen.

All copyrights and database rights with respect to this publication are expressly reserved. Nothing in this publication may be reproduced, copied, retrieved, made public or re-used or made available in any way whatsoever to third parties by way of printing, photocopying, microfilm or in any other way unless the Federatie Nederlandse Diervoederketen has given express written permission to do so. This publication has been compiled with great care; however, the Federatie Nederlandse Diervoederketen and Wageningen Livestock Research cannot be held liable in any way for the consequences of using the information in this publication. 


\section{Preface}

This documentation report is the result of a desk study performed by Paul Bikker and Machiel Blok of the department of Animal Nutrition, Wageningen Livestock Research, The Netherlands.

The aim of this desk study was to provide CVB recommendations for the allowance of standardized digestible phosphorus and calcium in the diet of growing pigs and reproductive sows. In 2003, Jongbloed et al. (2003) proposed recommendations for P supply of pigs for the CVB, based on a factorial approach. The present study is an update of the earlier study by Jongbloed et al. (2003) and incorporates new data and insights published thereafter, using a similar approach as Jongbloed et al (2003). This study was funded by the former Product Board Animal Feed and the Ministry of Economic Affairs.

Wouter Spek,

Wageningen, September 2017 


\section{Summary}

This study was conducted to update the digestible phosphorus (dP) and calcium (Ca) recommendations for growing pigs and sows. The last update was described by Jongbloed et al. (2003) and studies have been conducted since then, e.g. into mineral retention in the body and into factors influencing faecal endogenous losses of $P$. In addition, in the CVB Feed Table 2016, P content in ingredients is expressed on a standardised digestible basis, which requires recommendations expressed in the same unit. The $\mathrm{Ca}$ and $\mathrm{P}$ requirements are calculated using a factorial approach based on requirements for maintenance processes, retention of $\mathrm{Ca}$ and $\mathrm{P}$ in growing pigs, in maternal growth of sows and in foetuses, and excretion of $\mathrm{Ca}$ and $\mathrm{P}$ in milk of lactating sows. The $\mathrm{P}$ and $\mathrm{Ca}$ requirements are based on standardised digestibility of $\mathrm{P}$ and $\mathrm{Ca}$ in feed materials, meaning that basal endogenous losses from the digestive tract (faecal losses) are considered as an animal characteristic and included in the requirement for maintenance. These basal endogenous losses are influenced by body weight and feeding level of the pigs. We adopted values of $6 \mathrm{mg} \mathrm{P}$ and $8 \mathrm{mg} \mathrm{Ca} / \mathrm{kg}$ body weight (BW) per day in growing pigs and gestating sows, and $9 \mathrm{mg} \mathrm{P}$ and $12 \mathrm{mg} \mathrm{Ca} / \mathrm{kg}$ BW per day in lactating sows to account for losses related to the high feed intake in lactation. Inevitable urinary losses of $\mathrm{P}$ were taken as $1 \mathrm{mg} / \mathrm{kg}$ BW per day and losses of $\mathrm{Ca}$ provisionally estimated as $2 \mathrm{mg} / \mathrm{kg} \mathrm{BW}$ per day. Although urinary losses of $\mathrm{P}$ and Ca seem low at low inclusion levels in the diet, their excretion in the urine increases with increasing dietary intake. This is accounted for by adopting an efficiency of $98 \%$ for the utilisation of absorbed $\mathrm{Ca}$ and $\mathrm{P}$. Because of a lack of data on Ca digestibility of different ingredients, and limited information about the factors affecting the dynamics of Ca digestibility, the calcium requirements were expressed on the basis of total $\mathrm{Ca}$, using a constant standardised digestibility coefficient of 58\% (60\% for weaned piglets) in diets without microbial phytase. Assumptions for endogenous losses, digestibility and efficiency of utilisation of dietary Ca are poorly documented and require more attention since a high dietary Ca supply hampers $\mathrm{P}$ digestibility and a low Ca supply may limit $P$ retention in bone. Use of microbial phytase is recommended to improve both $\mathrm{P}$ and $\mathrm{Ca}$ digestibility and reduce total $\mathrm{Ca}$ content in the diet.

Allometric relationships $\left(Y=a X^{b}\right)$ were derived to relate the content and retention of $\mathrm{Ca}$ and $\mathrm{P}$ in the body of growing pigs to empty body weight (EBW), and a quadratic relationship between EBW and live weight (LW) was determined. Although the recommendations in this study are based on allometric relationships, for practical application a simplification is suggested to facilitate user specific calculations: $P$ retention is $5.32 \mathrm{~g} / \mathrm{kg}$ EBW gain, Ca retention is 1.55 and $1.60 \times P$ retention in pigs with LW below and above $45 \mathrm{~kg}$, respectively, and EBW is $0.95 \times \mathrm{LW}$. Furthermore we illustrated that the ratio between $\mathrm{Ca}$ and $\mathrm{P}$ retention increases with increasing dietary P-supply. This is a consequence of the priority for $P$ retention in soft tissue when dietary $P$ intake is limiting.

In gestating and lactating sows, relationships have been derived and updated to estimate the retention of $\mathrm{P}$ and $\mathrm{Ca}$ in maternal soft tissue (including the mammary gland) and bone, in placenta, fluids and foetuses in relation to day of gestation and parity of the sow. These equations are corrected to the actual body weight and mineral content (if available) of piglets at birth to assure that they agree with the performance of the sow. Mineral requirements in lactating sows were based on output in milk, retention in sucking piglets and mobilisation from body tissue. Relevant deviations from previous methods and results have been addressed. 
A summary of recommendations is provided in the table below

Animal category

STTD-P, g/EW

STTD-Ca, g/EW

\begin{tabular}{|l|c|c|c|}
\hline Piglets, week 1-2 post weaning & 3.8 & 5.9 & 9.8 \\
\hline Piglets, week 1-2 post weaning ${ }^{2)}$ & $3.4^{2)}$ & $5.0^{2)}$ & $8.4^{2)}$ \\
\hline Piglets, > 2 week post weaning & 3.2 & 5.0 & 8.4 \\
\hline Growing pigs, 25-45 kg LW & 2.8 & 4.4 & 7.6 \\
\hline Growing pigs, 45-70 kg LW & 2.4 & 3.8 & 6.5 \\
\hline Growing pigs, 70-120 kg LW & 2.0 & 3.3 & 5.6 \\
\hline Sows until d. 70 of gestation & 1.8 & 2.7 & 5.4 \\
\hline Sows > 70 d. of gestation & 2.4 & 3.9 & 7.8 \\
\hline Sows in complete gestation & 2.2 & 3.5 & 7.0 \\
\hline Sows in lactation & 2.8 & 4.2 & 8.4 \\
\hline
\end{tabular}

1) Total Ca derived from STTD-Ca using a standardised total tract digestibility of Ca of 60, 58 and $50 \%$ in diets for weaned pigs, growing pigs and sows, respectively.

2) Based on a transient reduction in $P$ retention of $15 \%$ (i.e. from 5.32 to $4.52 \mathrm{~g} / \mathrm{kg}$ empty body gain) to reduce the $\mathrm{Ca}$ content and buffer capacity of the weaning diet. 


\section{Table of contents}

$1 \quad$ Introduction $\quad 8$

$2 \quad$ Maintenance requirements of phosphorous 9

2.1 Urinary losses 9

2.2 Faecal losses 10

2.3 Summary 12

$3 \quad$ Phosphorus and calcium in body tissue 13

3.1 Body $\mathbf{P}$ and Ca content in published studies over time 13

3.2 Linear regression of $P$ and Ca versus empty body weight 13

3.3 Relationships between body weight and P and Ca mass 14

3.4 Mineral content in deposited body tissue 16

3.5 Mineral contents related to live weight 18

$\begin{array}{lll}3.6 & \text { Summary } & 19\end{array}$

4 Digestion and utilisation of phosphorus and calcium 20

$\begin{array}{lll}4.1 & \text { Phosphorus } & 20\end{array}$

4.1.1 Post-absorptive utilisation 20

$\begin{array}{ll}\text { 4.1.2 Digestion } & 21\end{array}$

$\begin{array}{ll}4.1 .3 & \text { Summary } \\ & 22\end{array}$

$\begin{array}{ll}4.2 \text { Calcium } & 22\end{array}$

4.2.1 Post-absorptive utilisation $\quad 22$

4.2.2 Digestion 23

4.2.3 Calcium - phosphorus interactions and calcium requirements 24

$\begin{array}{lll}\text { 4.2.4 Summary } & 26\end{array}$

$5 \quad$ Requirements of phosphorus and calcium of growing pigs 27

5.1 Requirements of weaned pigs 27

$\begin{array}{ll}\text { 5.1.1 Practical application } & 28\end{array}$

$\begin{array}{ll}5.2 & \text { Requirements of growing finishing pigs } 28\end{array}$

5.2.1 Influence of variation in growth performance 30

$\begin{array}{ll}\text { 5.2.2 Practical application } & 30\end{array}$

$6 \quad$ Requirements of reproductive sows 32

6.1 Introduction 32

6.2 Maintenance 32

6.3 Gestating sows 32

6.3.1 Retention in foetuses 32

6.3.2 Retention in other uterine tissues and mammary gland 35

6.3.3 Maternal mineral retention gain 36

$\begin{array}{lll}\text { 6.3.4 Digestibility of calcium in sows } & 37\end{array}$

6.3.5 Summary of calculated $\mathrm{Ca}$ and $\mathrm{P}$ requirements 37

$\begin{array}{ll}\text { 6.3.6 Practical application } & 39\end{array}$

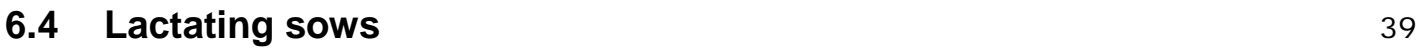

6.4.1 Calcium and phosphorus output in milk 39

6.4.2 Calculation of requirements 40

6.5 Discussion and practical application 41 
Annex 1 References of studies with growing pigs $\quad 50$

Annex 2 Characteristics of studies with growing pigs $\quad 52$

Annex 3 Year of publication and P and Ca content 53

Annex 4 Prediction equations for body P and Ca $\quad 54$

Annex 5 Residual plots for prediction of body P mass $\quad 55$

Annex 6 Residual plots for prediction of LN body P mass 56

Annex $7 \mathrm{P}$ and Ca retention in growing pigs $\quad 57$

Annex $8 \mathrm{Ca}$ and $\mathrm{P}$ required in weaned pigs $\quad 58$

Annex $9 \mathrm{Ca}$ and $\mathrm{P}$ in growing finishing pigs $\quad 59$

Annex 10 Composition of new born piglets $\quad 61$

Annex 11 Protein in placenta and uterine fluids $\quad 62$

$\begin{array}{ll}\text { Annex } 12 \text { Protein in the mammary gland } & 63\end{array}$

Annex 13 Description of sow characteristics $\quad 64$

Annex 14 Calculated P and Ca requirements of gestating sows 65

$\begin{array}{ll}\text { Annex } 15 \text { Body composition of pigs at weaning } & 70\end{array}$

$\begin{array}{ll}\text { Annex } 16 \text { Milk composition } & 71\end{array}$

Annex 17 Weekly P and Ca requirements of a first parity sow in lactation. $\quad 73$

Annex $18 \mathrm{P}$ and Ca requirements in lactation in relation to parity. $\quad 74$ 


\section{Introduction}

This report aims to provide recommendations for the allowance of phosphorus $(P)$ and calcium (Ca) in the diet of growing pigs and reproductive sows. Jongbloed et al. (2003) proposed an update of recommendations for $\mathrm{P}$ supply of pigs for the CVB, based on a factorial approach, which have been used since then by the Dutch feed industry. The present report incorporates new data and insights published thereafter, using a similar approach. The factorial estimation of phosphorus $(P)$ requirements of pigs is based on the requirements for maintenance (i.e. replacement of inevitable or basal endogenous losses in faeces and urine), the retention of phosphorus in the body and in products of conception, the excretion of phosphorus in milk and the efficiency with which digestible phosphorus is used for these processes. This method was first introduced by ARC (1967) and subsequently developed and used by Gueguen and Peréz (1981), Jongbloed et al., (2003), Jondreville and Dourmad (2005), GfE (2008) and NRC (2012). In this report we will subsequently address inevitable losses and maintenance requirements of phosphorus (Chapter 2), retention of calcium and phosphorus in body tissue in growing pigs (Chapter 3), digestion and utilisation of phosphorus and calcium in growing pigs (chapter 4), and combine the results to calculated the requirements of phosphorus and calcium in growing pigs (chapter 5 ). In chapter 6 , requirements of sows in lactation and gestation were calculated on the basis of tissue retention during gestation and milk production and tissue mobilisation in lactation. 


\section{Maintenance requirements of phosphorous}

In the context of phosphorus supply of pigs, maintenance requirements are defined as the basal endogenous losses from the digestive tract excreted in the faeces and inevitable losses excreted in the urine. Phosphorus losses by saliva and hair are generally assumed to be negligible. Present factorial models agree to a certain extent in the amount of $P$ required for maintenance or replacement of basal endogenous losses between 7 and $10 \mathrm{mg} / \mathrm{kg} \mathrm{BW}$ per day, but the justification for this estimate differs between authors. Jongbloed et al (2003) adopted a value of $7 \mathrm{mg} / \mathrm{kg}$ BW per day of which $6 \mathrm{mg}$ for faecal endogenous losses and 1 $\mathrm{mg}$ for urinary losses for growing pigs and sows. The value of $6 \mathrm{mg}$ was the mean between reported faecal losses of 2.9 and $8.8 \mathrm{mg} \mathrm{P} / \mathrm{kg}$ BW at low and high dietary intake of $\mathrm{P}$, respectively. Furthermore, Jongbloed et al. (2003) indicated that when requirements are expressed as apparently digestible $P$, implicitly faecal endogenous excretion is already taken into account. Nonetheless, the value of $6 \mathrm{mg} / \mathrm{kg}$ BW was adopted to account for an increase in faecal losses and a reduction in digestibility when dietary $P$ is included at a level close to the requirements. Jondreville and Dourmad (2005) adopted maintenance requirements of 10 $\mathrm{mg} / \mathrm{kg}$ BW per day to cover minimum urinary losses, assuming that endogenous faecal losses are accounted for in the calculated apparent digestibility coefficients. The value of 10 $\mathrm{mg} / \mathrm{kg}$ BW, adopted from Gueguen and Perez (1981), however, was based on data for pigs fed close to $P$ requirements in the study of Just (1972). In these animals, as much as $10-20 \%$ of incremental dietary P was excreted in the urine. The German GfE (2008) adopted a value of $10 \mathrm{mg} \mathrm{P} / \mathrm{kg} \mathrm{BW}$ per day for inevitable losses in faeces plus urine. This value was based on studies with deficient supply of P (Rodehutscord et al., 1998; Dilger and Adeola, 2006; Pettey et al., 2006), which is considered a prerequisite to determine inevitable losses of the mineral of study since endogenous excretion may depend on its dietary supply.

\section{$2.1 \quad$ Urinary losses}

The summary above indicates that despite the apparent similarity in adopted endogenous losses, Jongbloed et al. (2003) included these to account for a reduction in digestibility with increasing dietary P content and Jondreville and Dourmad (2005) used these to account for an increase in urinary excretion. Because of homeostatic mechanisms, phosphorus excretion in the urine increases with increasing dietary $\mathrm{P}$ intake and absorption. Any regulatory excretion of $P$ due to an excessive $P$ supply, however, should not be considered as part of the animal's requirement (Rodehutscord et al., 1998); hence inevitable urinary excretion needs to be determined at low dietary $P$ supply. Therefore, endogenous urinary losses of 10 mg as proposed by Gueguen and Perez (1981) and adopted by Jondreville and Dourmad (2005) cannot be regarded as minimal losses. Jongbloed (1987) reported P excretion in the urine of 0.7 and $0.4 \mathrm{mg} / \mathrm{kg} \mathrm{BW} / \mathrm{d}$ in growing pigs of 30 and $100 \mathrm{~kg}$, respectively, fed low $P$ diets $(\mathrm{P}<2 \mathrm{~g} \mathrm{P} / \mathrm{kg}$ ). In breeding sows, the urinary $\mathrm{P}$ excretion on low $\mathrm{P}$ diets was between 100 and $150 \mathrm{mg} / \mathrm{d}$, hence less than $1 \mathrm{mg} / \mathrm{kg}$ BW per day. Rodehutscord et al. (1998) 
reported a $\mathrm{P}$ excretion of $0.35 \mathrm{mg} / \mathrm{kg}$ BW per day in pigs from 20 to $150 \mathrm{~kg} \mathrm{BW}$ fed basal low $P$ diets ( $P \leq 1.3 \mathrm{~g} / \mathrm{kg}$ ). Petty et al. (2006) observed an urinary $P$ excretion between 0.2 and $0.5 \mathrm{mg} / \mathrm{kg}$ BW per day in pigs between 27 and $98 \mathrm{~kg}$ BW fed semi purified diets with a $P$ content of approximately $1 \mathrm{~g} / \mathrm{kg}$. Urinary $P$ excretion gradually increased with increasing dietary $\mathrm{P}$ content. These studies indicate that the inevitable urinary $\mathrm{P}$ losses are small and accounted for in the requirements by $1 \mathrm{mg} / \mathrm{kg}$ BW per day as adopted by Jongbloed et al. (2003). Higher levels of urinary excretion, especially at a dietary P content close to or beyond the requirements, reflect a response to increased $\mathrm{P}$ intake and absorption from the diet as part of the homeostatic regulation.

\section{$2.2 \quad$ Faecal losses}

Several authors assumed that endogenous faecal losses are accounted for in the apparent faecal digestibility coefficient (Jondreville and Dourmad, 2005) and hence do not need to be addressed in the requirements. This may depend on the protocol used in the digestibility studies. The assumption seems largely correct if a basal diet with a known (predetermined or simultaneously determined) $\mathrm{P}$ digestibility is diluted with a portion of test ingredient, as in the CVB-protocol. However, if the test ingredient is included in the basal diet at the expense of a $\mathrm{P}$-free ingredient, e.g. starch, the basal endogenous losses are largely attributed to the basal diet (GfE, 2008) and should be included in the requirements. To avoid confusion and inadequate accounting for the faecal endogenous losses, we propose to attribute these basal endogenous losses to the requirements of the animal and to regard specific endogenous losses, e.g. due to dietary fibre, as a characteristic of feed ingredients. This approach avoids the need to distinguish between specific endogenous losses and truly indigestible $P$ from feed ingredients and implies evaluation of feed materials on the basis of standardised total tract digestibility of $P$, as recently adopted in the NRC (2012).

A large number of studies have addressed the assessment of faecal endogenous phosphorus losses, using radioactive labelled dietary $\mathrm{P}$, semi-synthetic $\mathrm{P}$-free diets or the regression technique with extrapolation to zero $\mathrm{P}$ intake. Since ingredient characteristics, e.g. dietary fibre, may enhance the endogenous P losses, basal endogenous losses can best be determined using diets that cause little or no specific $P$ losses. Specific endogenous $P$ losses are (implicitly) accounted for in the digestibility coefficient when a feed ingredient is added to or included in a basal diet with known digestible P content. Studies using P-free diets have been largely based on semi-synthetic diets and are considered to reflect basal endogenous losses.

Based on a review of studies using labelled $P$, estimated the faecal endogenous losses in pigs (15-80 kg BW) fed low P diets with a mean P content of 2.9 (1.3-4.8) mg/kg BW per day. Rodehutscord et al. (1998) analysed a large number of balance studies using the regression technique and derived inevitable faecal losses per $\mathrm{kg}$ of BW per day of $5.9 \mathrm{mg}$ in growing pigs (33-106 kg) fed a number of different dietary ingredients. Pettey et al. (2006) used the regression technique to determine a dose response relationship for monosodium phosphate 
included in a semi-purified basal diet and reported endogenous $\mathrm{P}$ losses decreasing from 4.0 to $2.3 \mathrm{mg} / \mathrm{kg} \mathrm{BW}$ per day in pigs from 27 to $98 \mathrm{~kg} \mathrm{BW}$. In this study the (voluntary) feed intake decreased from 3.3 to 2.7 times maintenance (106 kcal/kg BW ${ }^{0.75}$ ) with increasing BW. Stein and co-workers determined basal endogenous $P$ losses between 139 and $211 \mathrm{mg} / \mathrm{kg}$ DMI per day in numerous studies using corn starch and gelatin based diets. In their unpublished work, endogenous $P$ losses varied between 206 and $246 \mathrm{mg} / \mathrm{kg}$ DMI per day in pigs from 10 to $129 \mathrm{~kg} \mathrm{BW}$ receiving diets at 2.5 times maintenance (Baker, 2011). The authors concluded that endogenous $\mathrm{P}$ losses expressed per $\mathrm{kg}$ DMI are independent of BW. However, in their studies the effects of BW and DMI cannot be separated because pigs were fed according to a scheme based on metabolic BW. Using their data, we derived a linear relationship between $\mathrm{P}$ losses and BW with a slope of $4.1 \mathrm{mg}$ per $\mathrm{kg}$ BW (Figure 1). Moreover, endogenous $P$ losses expressed per kg BW per day were relatively constant (4-6 $\mathrm{mg}$ ) between 20 and $130 \mathrm{~kg}$ BW with a higher loss of $6.9 \mathrm{mg} / \mathrm{kg} \mathrm{BW}$ in piglets of $10 \mathrm{~kg} \mathrm{BW}$. Thus, both BW and feed intake may be used to account for faecal endogenous $\mathrm{P}$ losses.
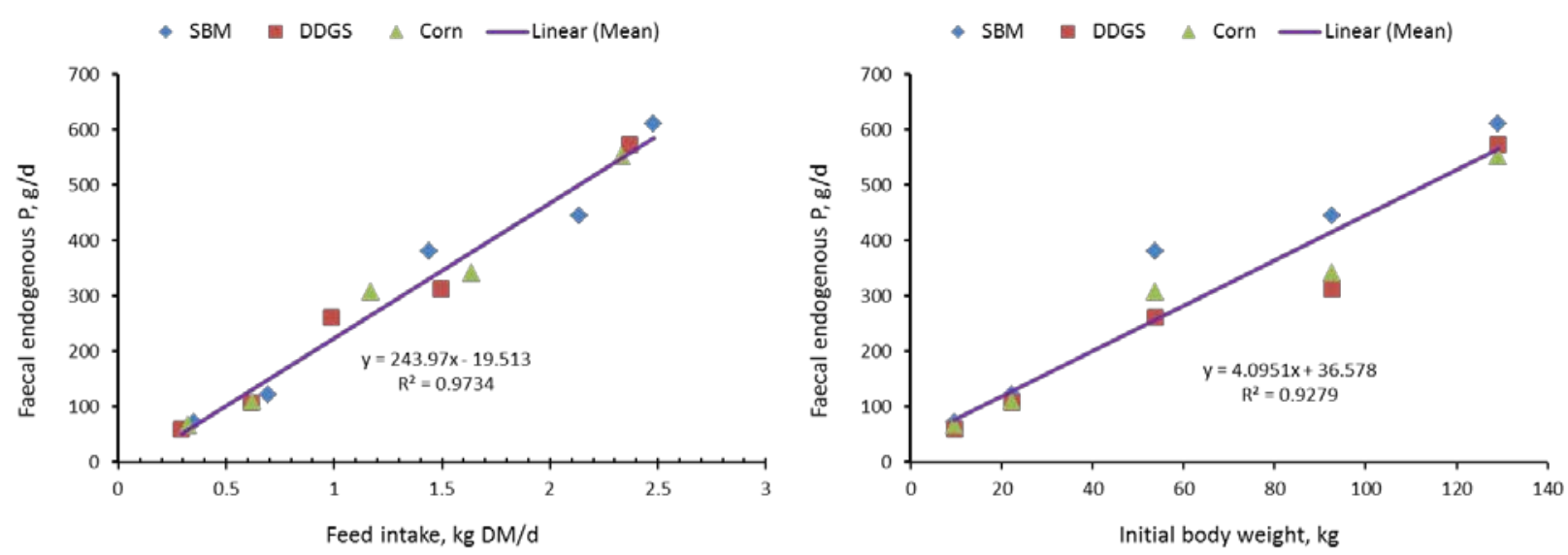

Figure 1. Faecal basal endogenous $P$ losses in pigs fed soybean meal (SBM), dried distillers grain with solubles (DDGS) or corn based diets, as determined by Baker (2011), expressed in relation to feed intake (left) and body weight (right) of the pigs.

In an attempt to separate the effects of BW and feed intake, Bikker et al. (2016) measured endogenous $P$ losses in growing pigs and gestating sows fed 2 or $3 \mathrm{~kg}$ of a semi-purified $\mathrm{P}$ free diet. In growing pigs (107 kg BW), the endogenous $\mathrm{P}$ excretion was not affected by feeding level when expressed per kg DMI (242 and $231 \mathrm{mg} / \mathrm{kg}$, respectively) and increased somewhat when expressed per $\mathrm{kg} \mathrm{BW}$ (4.2 and $5.0 \mathrm{mg} / \mathrm{kg}$, respectively). Using the same diets in gestating sows (195 kg BW), endogenous $\mathrm{P}$ losses were slightly reduced by the increase in feeding level when expressed per kg DMI (533 and $464 \mathrm{mg} / \mathrm{kg}$, respectively) and somewhat increased when expressed per $\mathrm{kg} \mathrm{BW}$ (5.3 and $5.9 \mathrm{mg} / \mathrm{kg}$, respectively). These results indicate that both $\mathrm{BW}$ and feed intake influence the endogenous $\mathrm{P}$ losses. In (growing) pigs with a feed intake between approximately 2.5 and 3.5 times maintenance, our results agree with those of Stein and co-workers with losses between approximately 150 and $250 \mathrm{mg} \mathrm{P} / \mathrm{kg}$ DMI per day. However, in gestating sows, with a twice higher BW, losses expressed per kg DMI were twice higher as well. Hence, expression per kg DMI would result 
in an underestimation of the requirements for gestating sows. Endogenous losses expressed per kg BW were relatively similar for sows and growing pigs and in the same range as derived from the results of Stein and co-workers. Thus, for factorial calculation of basal faecal endogenous losses as part of maintenance requirements, the expression per $\mathrm{kg} \mathrm{BW}$ seems relatively robust over a wide BW range. Since the feed intake in practice is at the higher end of the studies discussed, we adopted a value of $6 \mathrm{mg} \mathrm{P} / \mathrm{kg} \mathrm{BW}$ per day for the faecal endogenous loss. In lactating sows with a high feeding level, we anticipate that this value may underestimate endogenous faecal losses. Because of a lack of data in lactation, we adopted a value of $9 \mathrm{mg} / \mathrm{kg}$ BW per day for lactating sows to account for a mean feed intake of $6 \mathrm{~kg} / \mathrm{d}$ and the additional endogenous losses of $212 \mathrm{mg} \mathrm{P} / \mathrm{kg} \mathrm{DMI}$ as observed by Bikker et al. (2016).

In studies to determine $P$ digestibility growing pigs with a mean body weight of $60 \mathrm{~kg}$ are used. These are fed a diet with $1.08 \mathrm{EW}(9.5 \mathrm{MJ} \mathrm{NE} / \mathrm{kg})$ at a feeding scheme of 2.8 times maintenance. Consequently their feed intake is approximately $1.9 \mathrm{~kg}$. From these data an endogenous $\mathrm{P}$ loss of $220 \mathrm{mg} / \mathrm{kg}$ DM is calculated. This is in good agreement with the mean value of $200 \mathrm{mg} / \mathrm{kg}$ DM adopted by CVB Feed Table 2016 to calculate the STTD of P.

\subsection{Summary}

To calculate maintenance $P$ requirements, we adopted a value of $1 \mathrm{mg} / \mathrm{kg}$ BW per day for urinary losses and 9 and $6 \mathrm{mg} / \mathrm{kg}$ BW per day to replace inevitable faecal P losses in lactating sows and other categories of pigs (weaned pigs, growing pigs and gestating sows), respectively. 


\section{Phosphorus and calcium in body tissue}

Phosphorus requirements of growing pigs are largely determined by deposition in lean tissue, organs and bone. Jongbloed et al. (2003) collected and analysed a number of studies in which $\mathrm{P}$ content in the body of pigs was determined using diets that were assumed to allow near maximum bone mineralisation. Their dataset comprised 42 treatment groups from 12 publications of which 35 were used to determine the relationship between EBW and $P$ and $\mathrm{Ca}$ in the body. Their original dataset has now been extended with studies published since 1990 to date and comprised 23 studies with 104 treatment groups from pigs at weaning to a maximum of $135 \mathrm{~kg} \mathrm{BW}$. Data of treatment groups were included when the digestible phosphorus content of the diets met or exceeded the CVB (2012) recommendations for the digestible $P$ to energy ratio based on Jongbloed et al. (2003). A description of the complete dataset is provided in Annex 1, a summary of descriptive characteristics is provided in Annex 2. Within studies, data were considered as separate treatment groups when the pigs differed in sex, genotype, body weight or dietary digestible P supply. Data of treatment groups were combined when the (dietary) treatments were not directly related to P-metabolism. The square root of the number of pigs per treatment group was used as weighing factor in the regression analysis.

\subsection{Body P and Ca content in published studies over time}

As a first step, content of $\mathrm{Ca}$ and $\mathrm{P}$ in the empty body $(\mathrm{g} / \mathrm{kg})$ and $\mathrm{Ca} / \mathrm{P}$ ratio were analysed using simple linear regression with year of publication as the independent variable. The results, included in Annex 3 , indicate that $P$ content in the empty body non-significantly decreased ( $P=0.165)$ from approximately $5.4 \mathrm{~g} / \mathrm{kg}$ EBW in 1985 to $5.2 \mathrm{~g} / \mathrm{kg}$ in 2015. The Ca content decreased from 8.8 to $7.9(P=0.009)$ in the same period. This would suggest a decrease in body $P$ and $C a$ content of 0.2 and $0.9 \mathrm{~g} / \mathrm{kg}$ in the past 30 years. However, the graphs in Annex 3 illustrate that a few early studies (i.e. Fandrejewsky et al., 1986 and Just et al., 1985) largely contributed to the high empty body $P$ content in these early years. Presumably, this can be explained by the dietary $\mathrm{P}$ content in these studies, being approximately 1.5 to 2 times the present CVB-recommendations. In later years, none of the other studies in the dataset used such a high dietary digestible $\mathrm{P}(\mathrm{dP})$ content (over $4 \mathrm{~g}$ $\mathrm{dP} / \mathrm{EW}$ in growing pigs). After provisional exclusion of these two studies from the dataset, no significant effect of year of publication on empty body P content was observed. Hence, the data do not substantiate a significant development in body $\mathrm{P}$ content over time beyond the effects caused by variation in dietary $P$ content. Because of the absence of an overall effect of time, further analysis of body $\mathrm{P}$ and $\mathrm{Ca}$ content in this report are based on the dataset since 1985, including Fandrejewsky et al. (1986) and Just et al. (1985). The data were analysed for relationships between $\mathrm{Ca}$ and $\mathrm{P}$ content as dependent variables and body mass and body nitrogen content as independent variables.

\subsection{Linear regression of $\mathrm{P}$ and $\mathrm{Ca}$ versus empty body weight}

In order to determine the relationship between body weight and $\mathrm{P}$ content in comparison to methods previously used by Jongbloed et al. (2003) and other references (i.e., Jondreville 
and Dourmad, 2005; NRC, 2012), linear, quadratic and allometric models were used with empty body weight and body nitrogen (protein) mass as explanatory variables. The complete results are included in Annex 4. For both EBW and body nitrogen mass a linear effect $(P<0.001)$ on body $P$ and $C a$ mass was observed without significant intercept and quadratic effect. Consequently, the $\mathrm{P}$ and $\mathrm{Ca}$ mass could be described as a constant proportion of EBW or protein mass as summarised for EBW in the equations below.

(1) $P(g)=5.33 \pm 0.043$ EBW $(\mathrm{kg})\left(R^{2}=97.7\right)$

(2) $\mathrm{Ca}(\mathrm{g})=8.57 \pm 0.11 \mathrm{EBW}(\mathrm{kg})\left(\mathrm{R}^{2}=95.6\right)$

The results in Annex 4 allow comparison of the relationships using either EBW or whole body protein (nitrogen) mass as independent variable. The proportion of explained variance $\left(R^{2}\right)$ in body $\mathrm{Ca}$ and $\mathrm{P}$ content was marginally lower and the residual variation marginally higher when body $\mathrm{N}$ was used as explanatory variable. Hence, our results do not substantiate that the use of body protein mass is preferred above EBW for the prediction of body $\mathrm{P}$ and $\mathrm{Ca}$ content, as suggested by NRC (2012).

The regression line and residuals have been plotted for $P$ mass in Annex 5. Despite the good overall fit (high $\mathrm{R}^{2}$ ) the residual plot indicates an increase in standardised residuals and 95\% confidence interval of estimates with increasing EBW. This indicates that a log transformation of the data would be appropriate. This will be addressed in the next paragraph.

\subsection{Relationships between body weight and $\mathrm{P}$ and Ca mass}

As described by Jongbloed et al. (2003), allometric functions have been used to describe the relationships between different body components. These functions were originally introduced to describe the relative development of physical body components, e.g. skeleton, muscle and fat tissue, rather than chemical components (e.g. Walstra, 1980). Nonetheless, allometric functions seem useful for $\mathrm{Ca}$ and $\mathrm{P}$ since these minerals are largely related to the development of bone tissue whereas $\mathrm{N}$ is closely related to the development of muscle tissue. The general function in its simplest form would be $Y=a X^{b}$ in which $Y$ is the response variable, e.g. $\mathrm{P}$ mass, $\mathrm{X}$ is the independent or explanatory variable, e.g. EBW, "a" is a constant and " $b$ " is the growth coefficient. An estimate of $b=1$ implies that body component $Y$ develops as a constant proportion of $X$; if $b<1$ or $b>1, Y$ develops less or more than proportionate to $X$. In general the regression coefficients are estimated after logarithmic transformation and subsequent linear regression, thus also assuring homogenous distribution of residual variance: In $Y=\ln a+b \ln X$. In Annex 4 the complete results of analyses of allometric relationships, expressing $\mathrm{P}$ and $\mathrm{Ca}$ as a function of EBW or body protein mass were included. The results based on EBW were summarised below.

(3) $\operatorname{Ln} P(g)=1.67 \pm 0.039+1.0004 \pm 0.0099 \operatorname{Ln}$ EBW $(\mathrm{kg})\left(\mathrm{R}^{2}=99.0\right)$

(4) $\operatorname{Ln~Ca~}(\mathrm{g})=2.06 \pm 0.054+1.018 \pm 0.014 \mathrm{Ln} \mathrm{EBW}(\mathrm{kg})\left(\mathrm{R}^{2}=98.4\right)$

In comparison to the linear relationships (Equation 1 and 2) presented earlier, the allometric relationships gave a slightly better prediction (higher $\mathrm{R}^{2}$ ) of the mass of $\mathrm{P}$ and $\mathrm{Ca}$ in the body. Moreover, the residuals were more homogenously distributed, as illustrated in Annex 6 . The exponent (b) of 1.0004 for $P$ in equation 3 indicates that the development of the $P$ mass in 
the body was proportional to the growth of the empty body whereas the development of $\mathrm{Ca}$ $(b=1.018)$ was somewhat more than proportional to the EBW. This was confirmed when the Ca mass was related to the $P$ mass, with an exponent $b$ of 1.014 (equation 5) indicating a slightly more than proportional deposition rate of Ca compared to $\mathrm{P}$.

(5) $\operatorname{Ln~Ca~}(g)=0.385 \pm 0.046+1.0135 \pm 0.0083 \operatorname{Ln} P(g)\left(R^{2}=99.4\right)$

The results in Annex 4 allow comparison of the relationships using either Ln EBW or Ln N (body nitrogen mass) as independent variable. In line with the previous paragraph, the results do not indicate that the use of body protein mass improved the prediction of the body $\mathrm{P}$ and $\mathrm{Ca}$ content. We acknowledge that body $\mathrm{N}$ content was not determined in all studies in the dataset (Annex 4) and that the lower number of studies might have reduced the accuracy of the response relationships. However, when the dataset was restricted to studies that included both EBW and body $\mathrm{N}$ content, EBW still gave an equally good prediction of $\mathrm{P}$ and Ca content (higher $\mathrm{R}^{2}$, lower SE) as body $\mathrm{N}$ content. This is in agreement with the results of Pettey et al. (2015) analysing body P content in pigs from 20-120 kg BW. Nonetheless, NRC (2012) and Symeou et al. (2014a), largely using the same published data, related the body $P$ content to the body N content using a linear (Symeou et al. 2014a) or quadratic (NRC, 2012) relationship. The linear coefficient of $33.7 \mathrm{~g} \mathrm{P} / \mathrm{kg}$ body protein deposition derived by Symeou et al. (2014a) is close to the value of $32.5 \mathrm{~g} \mathrm{P} / \mathrm{kg}$ body protein determined by linear regression in our dataset (Annex 4, $203.2 \mathrm{~g} \mathrm{P} / \mathrm{kg} \mathrm{N}$ ).

In Figure 2 the predicted total body $\mathrm{P}$ and Ca mass ( $\mathrm{g}$ ) and the $\mathrm{P}$ and Ca content ( $\mathrm{g} / \mathrm{kg} \mathrm{EBW}$ ) have been plotted for the linear and allometric functions (Equation 1 to 4). The predicted total body mass is similar for the linear and allometric functions (left figure). The Ca content per $\mathrm{kg}$ EBW based on the allometric function is slightly below the content predicted by the linear function and gradually increases with BW (right figure). The allometric relationship was used to determine the $\mathrm{P}$ and $\mathrm{Ca}$ content in retained tissue in the next paragraph.
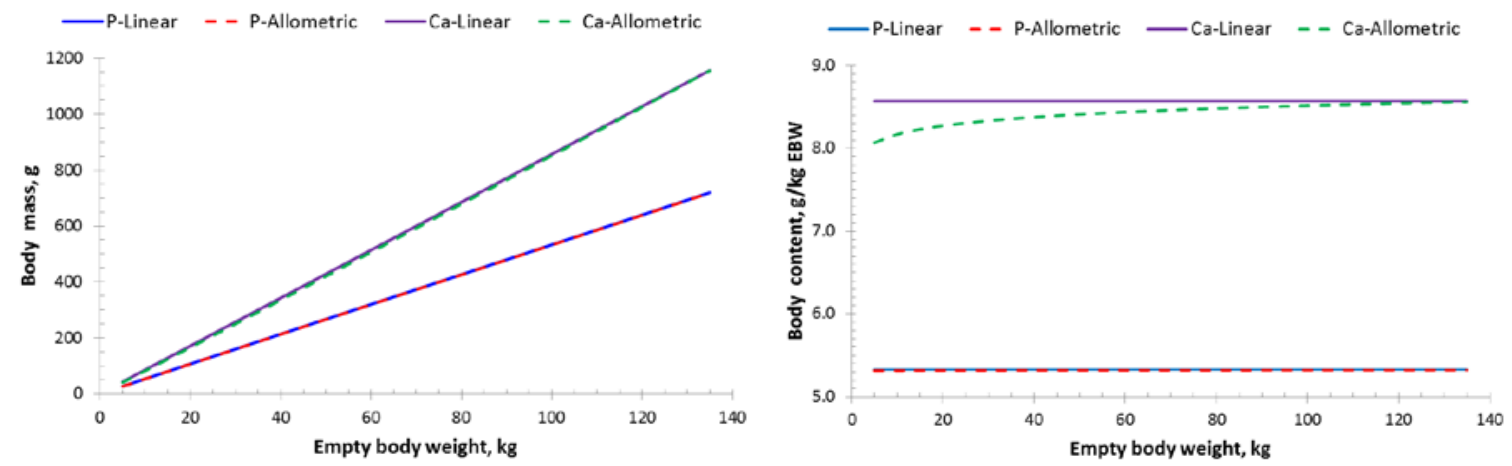

Figure 2. Relationship between empty body weight (EBW) and body phosphorus (P) and calcium (Ca) mass (g) (left panel) and body P and Ca content (g/kg EBW) (right panel) based on studies published since 1985 predicted with the linear and allometric functions (Equations 1 to 4$)$ described in the text. 


\subsection{Mineral content in deposited body tissue}

The diet should allow adequate deposition of phosphorus and calcium in retained body tissue in each phase of the growth curve. Therefore, the $\mathrm{P}$ and Ca contents per unit retained body tissue were determined as the first derivative $(d Y / d X)$ of the relationship between EBW and mineral mass. The derivative for the linear relationship $(Y=a X) d Y / d X$ is the constant " $a$ ", for the allometric relationship $\left(Y=a X^{b}\right)$ the derivative $d Y / d X$ is $a b X^{(b-1)}$. In Figure 3 , the relationship between EBW and $P$ and Ca retention in body tissue, expressed per kg EBW gain is presented. The linear relationships indicate a constant composition of retained body tissue with $5.33 \mathrm{~g} \mathrm{P}$ and $8.57 \mathrm{~g}$ Ca per $\mathrm{kg}$ EBW. The allometric relationship indicated a constant $P$ content in body gain of $5.32 \mathrm{~g} / \mathrm{kg}$. The relationship derived by Jongbloed et al. (2003) showed an increase from 5.40 to $5.47 \mathrm{~g} \mathrm{P} / \mathrm{kg}$ EBW. These results indicate that the effect of EBW on the $P$ retention per unit body tissue was very small. Based on the allometric relationships, between 5 and $125 \mathrm{~kg}$ EBW the Ca retention increased from 8.2 to $8.7 \mathrm{~g} \mathrm{Ca} / \mathrm{kg}$ EBW using the new dataset. The relationship derived by Jongbloed et al. (2003) showed an increase from 8.2 to $9.3 \mathrm{~g} \mathrm{Ca} / \mathrm{kg}$ EBW. Consequently, in each of the two datasets both in absolute and relative terms, the effect of EBW on Ca retention was bigger than the effect on $P$ retention in retained body tissue. The mean $P$ and $C a$ content in retained tissue was somewhat lower in the dataset with more recent studies compared to Jongbloed (2003), due to the inclusion of recent studies with lower values for the body $\mathrm{P}$ and $\mathrm{Ca}$ contents.
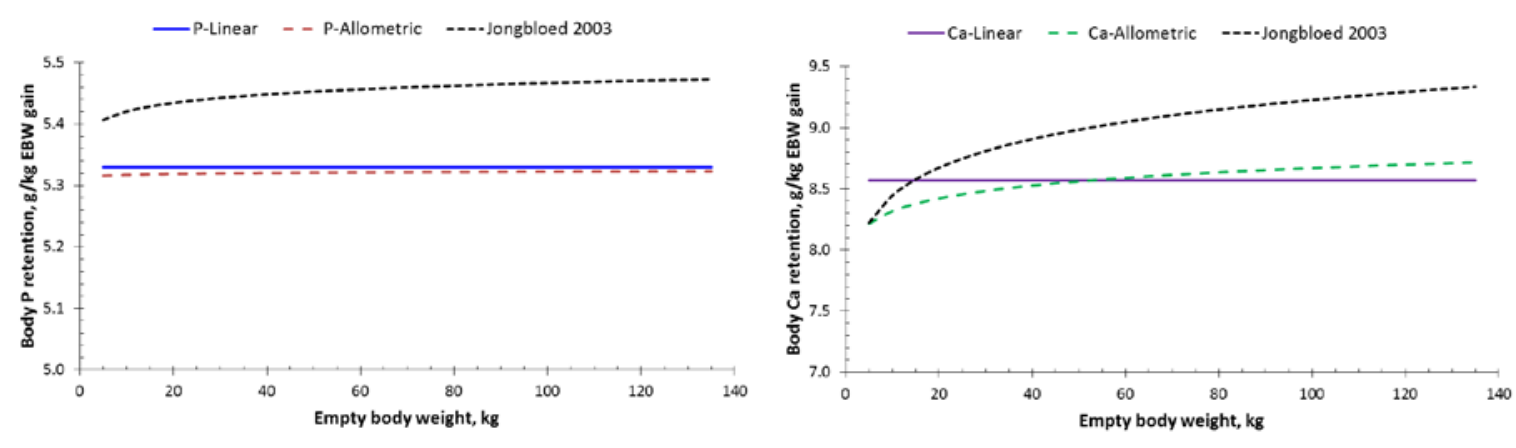

Figure 3. Retention of phosphorus (left panel) and calcium (right panel) per unit of retained body tissue (g mineral/kg EBW gain) as a function of EBW based on studies published since 1985, using linear and allometric relationships between EBW and body P and Ca mass as described in the text and by Jongbloed et al. (2003).

The bigger increase in Ca content with increasing EBW (Figure 3) is reflected in the increase in $\mathrm{Ca} / \mathrm{P}$ ratio with increasing $\mathrm{EBW}$ in Figure 4. The higher mean $\mathrm{P}$ and $\mathrm{Ca}$ content and the bigger increase in Ca content with EBW as observed in the older dataset (Jongbloed et al., 2003) may be a consequence of a higher dietary $P$ and Ca content and subsequent body mineral retention. The mineral content in soft tissue (muscle, fat and organs) is relatively constant, with a P content of approximately $3.5 \mathrm{~g} / \mathrm{kg}$ dry matter (DM) and a relatively low Ca content 0.2-0.5 g/kg DM (Just Nielsen, 1973; Lüdke et al., 1990). When the dietary P supply is low, preference is given to $P$ retention in soft tissue and a reduced proportion is retained in the bone matrix. An increase in dietary $P$ content has limited effect on the $P$ content in soft tissue whereas the $P$ retention in bone is enhanced, both absolute and as proportion of the total $P$ retention (De Wilde and Jourquin, 1992). Since $P$ in bone is largely retained as 
hydroxyapatite with a ratio of $\mathrm{Ca} / \mathrm{P}$ of approximately 2.16 , this would also increase the $\mathrm{Ca} / \mathrm{P}$ ratio in the retained body tissue. To verify this effect the $\mathrm{Ca} / \mathrm{P}$ ratio was analysed in the dataset of the dose response study with varying dietary $\mathrm{P}$ content in growing pigs of Bikker et al. (2013). Subsequently, the proportion of $P$ in bone was calculated with the ratio of Ca/P of 2.16 and assuming that $99 \%$ of body $\mathrm{Ca}$ is retained in bone (Just Nielsen, 1973; Moinizadeh, 1973; Jongbloed, 1987). The body Ca/P ratio increased from 1.4 to 1.6 in growing pigs (20$50 \mathrm{~kg})$ and 1.45 to 1.65 in late finisher pigs (80-125 kg) when dietary dP content increased from 50 to $130 \%$ of current CVB recommendations. The results in Figure 5 demonstrate a linear increase in $\mathrm{Ca} / \mathrm{P}$ ratio (slope $0.10 \pm 0.008$ ) and proportion of $\mathrm{P}$ in bone (slope $4.8 \pm 0.4$ ) with increasing $P$ content in the EBW, irrespective of BW. In addition, the $\mathrm{Ca} / \mathrm{P}$ ratio and proportion of $\mathrm{P}$ in bone were higher in $125 \mathrm{~kg}$ pigs, confirming the increase with EBW shown in Figure 4. In Fandrejewsky et al. (1986) the Ca/P ratio was as high as 1.75 in pigs with an empty body $\mathrm{P}$ content of $5.85 \mathrm{~g} / \mathrm{kg}$ EBW. This effect of $\mathrm{P}$-supply on retained Ca/P ratio in the body is generally not taken into account, apart from the model of Létourneau-Montminy et al. (2015) who distinguished bone and soft tissue pools. In this model the composition of the soft tissue, including $P$ content, is assumed constant and largely determined by protein and energy intake, thus retaining part of the absorbed $\mathrm{P}$ and a small amount of $\mathrm{Ca}$. The remaining $\mathrm{Ca}$ and $\mathrm{P}$ are deposited in bone in a fixed ratio until either of the two becomes limiting. This approach allows accounting for the influence of actual $\mathrm{dP}$ intake on the optimal $\mathrm{Ca} / \mathrm{P}$ ratio, but it is not feasible in the present factorial calculation of the requirements where dietary $\mathrm{dP}$ is an output rather than an input parameter. Hence, we use the allometric responses described above for $\mathrm{Ca}$ and $\mathrm{P}$-retention and $\mathrm{Ca} / \mathrm{P}$ ratio. For practical use these can be simplified by using a Ca/P ratio of 1.55 from weaning to $45 \mathrm{~kg}$ body weight and a value of 1.60 for pigs between 45 and $125 \mathrm{~kg}$ (Figure 4). This is slightly less than the value of 1.65 realised in our study cited above (Bikker et al., 2013), which was realised at $130 \%$ of CVB requirements (Jongbloed et al. 2003) and hence above requirements in practical circumstances.

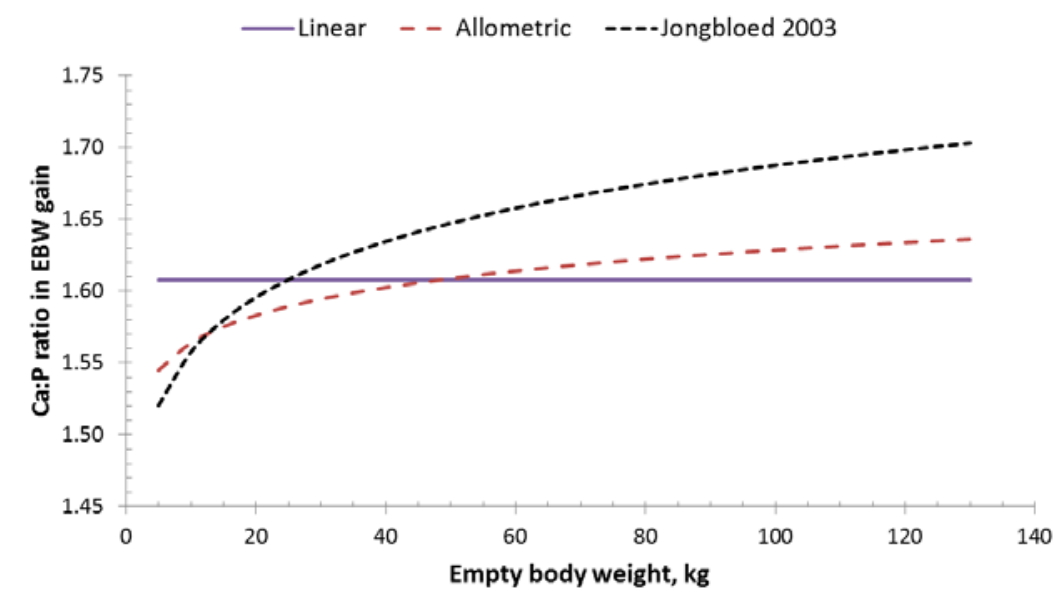

Figure 4. Ratio between calcium and phosphorus deposition per unit empty body weight (EBW) gain for the $\mathrm{Ca}$ and $\mathrm{P}$ retention, as described in Figure 2, as a function of EBW. 

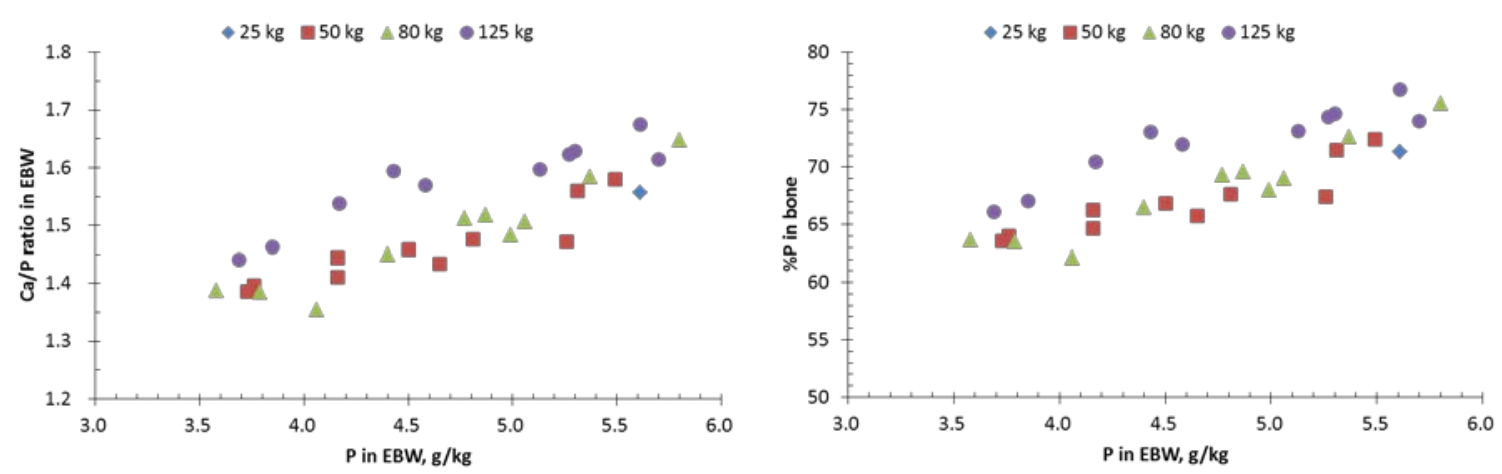

Figure 5. Analysed $\mathrm{Ca} / \mathrm{P}$ ratio and calculated proportion of body $\mathrm{P}$ retained in bone (assuming $99 \%$ body $\mathrm{Ca}$ in bone and a $\mathrm{Ca} / \mathrm{P}$ ratio of 2.16 in bone) as a function of empty body $\mathrm{P}$ content, calculated in the dose response study with dietary $\mathrm{P}$ content in growing pigs by Bikker et al. (2013).

\subsection{Mineral contents related to live weight}

When growth simulation models are used to calculate $\mathrm{Ca}$ and $\mathrm{P}$ retention, these can be directly related to the predicted empty body gain or nitrogen (protein) retention, using the equations described above. For practical purposes, without using a model, recalculation of EBW to LW allows simple application of the results of this study. For this purpose, the relationship between EBW and LW was determined using a linear regression model. There were no major differences between the different models (Annex 4). Using the model with significant linear and quadratic component, EBW as a proportion of LW increased from $93.5 \%$ at $10 \mathrm{~kg}$ to $95.5 \%$ at $130 \mathrm{~kg} \mathrm{LW}$. The equations were in good agreement with Jongbloed et al. (2003). The resulting $P$ and $\mathrm{Ca}$ content per kg live weight gain increased slightly with increasing BW as illustrated in Figure 6 and in detail included in Annex 7.

(6) $\operatorname{EBW}(\mathrm{kg})=0.934 \pm 0.0073 \mathrm{LW}+0.000162 \pm 0.000072 \mathrm{LW}^{2}(\mathrm{~kg})(\mathrm{R} 2=99.9)$
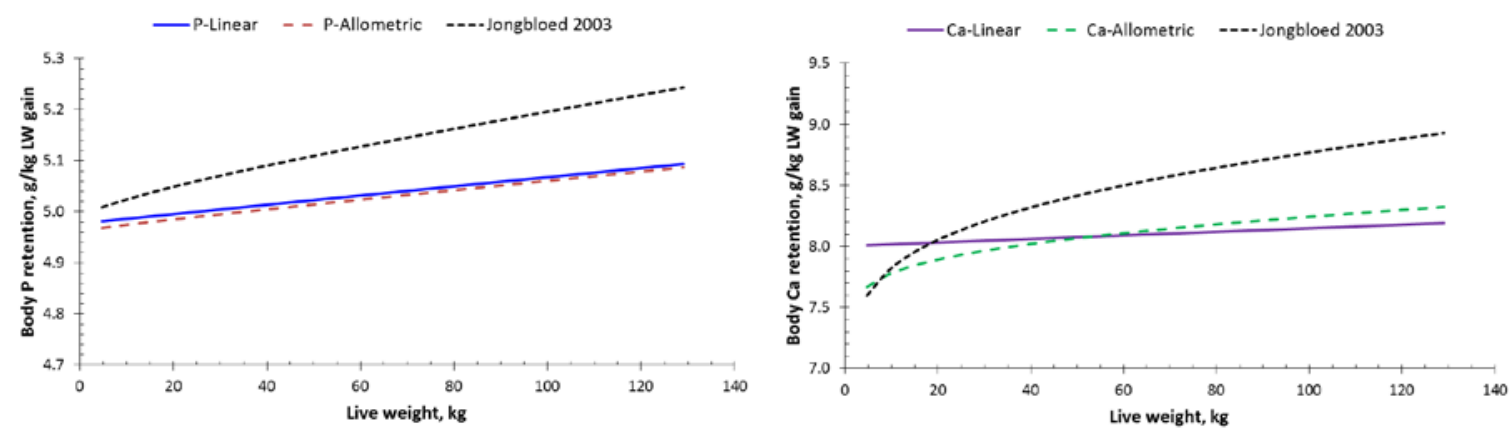

Figure 6. Content of phosphorus (left panel) and calcium (right panel) per kg live weight gain based on studies published since 1985 using linear and allometric relationships between EBW and body P and Ca mass as described in the text and by Jongbloed et al. (2003). 


\subsection{Summary}

For $\mathrm{P}$ and Ca-retention in body tissue in relation to EBW of the pigs, we adopted the allometric equations 3 and 4, and we used equation 6 to recalculate retention based on EBW to retention based on LW of pigs. For practical application, these results can be simplified using a constant P-retention of $5.32 \mathrm{~g} / \mathrm{kg}$ EBW gain and $5.05 \mathrm{~g} / \mathrm{kg}$ live weight gain with EBW is $0.95 \times \mathrm{LW}$. For the ratio of Ca/P-retention, values of 1.55 and 1.60 for pigs with $\mathrm{LW}$ below and above $45 \mathrm{~kg}$, respectively, can be used. A reduction in $\mathrm{P}$ supply will proportionally reduce body $\mathrm{P}$ and $\mathrm{Ca}$ content (in bone) and the ratio of $\mathrm{Ca} / \mathrm{P}$ retention. $\mathrm{A} 10 \%$ reduction in body $\mathrm{P}$ content (from 5.3 to $4.8 \mathrm{~g} / \mathrm{kg}$ ) will reduce the $\mathrm{Ca} / \mathrm{P}$ ratio by approximately 0.05 . 


\section{Digestion and utilisation of phosphorus and calcium}

\subsection{Phosphorus}

In the previous chapters $\mathrm{P}$ requirements are described as net or post absorptive requirements of $P$ for maintenance processes and tissue deposition. To convert the net requirements into digestible $P$ requirements, the relationship between digestion and absorption of $P$ from feed ingredients and processes influencing the post absorptive utilisation need to be taken into account. Jongbloed et al. (2003) assumed complete $(100 \%)$ utilisation of phosphorus digested and absorbed according to the digestibility coefficients of feed ingredients as for example included in the CVB-table. The German GfE adopted an efficiency of utilisation of digestible P of 0.95 based on studies of Rodehutscord et al. (1998) and Pettey et al. (2006). NRC (2012) assumed a maximum efficiency of 0.95 for P retention in individual pigs when $P$ intake is just below requirements. To account for variation between individual pigs this efficiency was reduced to 0.77 to calculate $P$ requirements of both growing pigs and reproductive sows. This approach is based on data and simulations for lysine utilisation in individual pigs (e.g. Pomar et al., 2003) since individual variation in $P$ utilisation has not been addressed in published literature.

\subsubsection{Post-absorptive utilisation}

The degree of post absorptive utilisation of $\mathrm{P}$ is reflected by urinary $\mathrm{P}$ excretion and can be determined by relating $\mathrm{P}$ retention and/or urinary $\mathrm{P}$ excretion to digestible (absorbed) $\mathrm{P}$ intake. Rodehutscord et al. (1998) reanalysed a series of balance experiments with diets suboptimal in $\mathrm{P}$ content in piglets and growing pigs and concluded that utilisation of absorbed $P$ for $P$ retention was 0.99 , hence almost complete. In a balance study, Pettey et al. (2006) showed an utilisation of absorbed $P$ above 0.98 at low levels of $P$ intake. With increasing $P$ intake to 2.0 and $1.7 \mathrm{~g} / \mathrm{kg}$ feed (14.3 MJ ME/ $\mathrm{kg}$ ) in 59 and $98 \mathrm{~kg}$ pigs, $P$ utilisation decreased to approximately 0.90 without clear indication that a maximum in $\mathrm{P}$ retention (plateau level) was reached. This is in line with results of a serial slaughter experiment of Bikker et al. (2013) in growing pigs from 25 to $125 \mathrm{~kg}$ body weight, who observed a gradual decrease in utilisation of absorbed $P$ with increasing $P$ intake. The mean utilisation from $25-125 \mathrm{~kg}$ was close to 1.00 with $\mathrm{P}$ intake below $90 \%$ of CVB recommendations and decreased to 0.95 at higher levels of $P$ intake. Stein et al. (2008) studied the effect of increasing $P$ intake from MCP in a balance study and observed a retention (balance) between 0.94 and 0.97 of absorbed $P$. At the highest $P$ intake level, the retention decreased to 0.90 of absorbed $P$, presumably because $\mathrm{Ca}$ became limiting for $\mathrm{P}$ retention in bone tissue. Liu et al. (2016) observed a retention of absorbed $\mathrm{P}$ of $99 \%$ in $30 \mathrm{~kg}$ pigs, by the authors related to the lower range of dietary P-content compared to Stein et al. (2008). Stein et al. (2011) observed a constant utilisation of absorbed $\mathrm{P}$ of approximately 0.95 when dietary Ca was at or above the level required to maximise $P$ retention in a balance study with young growing pigs between 20 and $30 \mathrm{~kg}$ supplied with a dietary $\mathrm{P}$ close to the estimated requirements. Although the increase of dietary $\mathrm{Ca}$ above the level for maximum $\mathrm{P}$ retention decreased $\mathrm{P}$ absorption and retention, the post absorptive utilisation remained constant. Similarly, results of a balance study by Gonzalez-Vega et al. (2016a) indicate an utilisation of absorbed P of 0.97 when Ca is at or above the level for maximum retention. Overall, these results suggest that at low levels of $\mathrm{P}$ intake, when $\mathrm{Ca}$ is not limiting, the absorbed $\mathrm{P}$ is almost completely utilised for $\mathrm{P}$ 
retention and urinary excretion is very small and presumably limited to minimal endogenous losses. With increasing $P$ intake, the reabsorption of $P$ from primary urine in the kidney may decrease, resulting in a gradual increase in urinary $P$ excretion and decrease in the utilisation of absorbed $P$. Based on literature we propose to use a factor of 0.98 for the efficiency of utilisation of absorbed $\mathrm{P}$ close to the requirements, provided that absorbed $\mathrm{Ca}$ is not limiting $P$ deposition. This is in between recent models proposed by NRC (2012) and Symeou et al. (2014b), using a value of 0.95 and Létourneau-Montminny et al. (2015) who adopted complete utilisation of absorbed $P$ (i.e. no increase in urinary $P$ above the minimum endogenous excretion) until maximum bone mineralisation is reached. We acknowledge that the use of a constant factor for the efficiency of absorbed $\mathrm{P}$ utilisation may be a simplified representation of a gradual decrease with increasing dietary $P$ supply.

\subsubsection{Digestion}

Based on the estimation of (basal) endogenous losses, the retention of $\mathrm{P}$ and the post absorptive utilisation of $P$ as described above, the digestible $P$ requirements can be calculated. Because basal endogenous losses from the digestive tract are included in the maintenance requirements of the animal, the diet digestible $\mathrm{P}$ content needs to be expressed on a standardised digestible basis, corrected for basal endogenous losses in the faeces caused by intake and digestion of the diet. Practical application requires that the standardised digestible $\mathrm{P}$ content of the feed ingredients and the complete diet are known. In conjunction to this report, CVB provides a table with the digestible P content of commonly used feed ingredients. This will provide a practical basis for the application of the recommendations. Nonetheless, the use of static values for $P$ digestibility undervalue the dynamic influences of dietary factors, including total $P$, phytate $P(P P)$ and non-phytate $P$ (NPP) and Ca content, and the presence of microbial and intrinsic phytase in the diet. The $P$ digestibility of feed ingredients has generally been determined at marginal levels of $P$ supply to assure maximum absorption of $P$. At a level of $P$ intake close to the requirements digestibility (i.e. absorption) of $\mathrm{P}$ may be reduced because of a less efficient (active or passive) absorption process. Recently, we studied the effect of an incremental dietary $P$ content from MCP on absorption and retention of $P$ in growing pigs (Bikker et al., 2013). The results indicated a decrease in relative $\mathrm{P}$ absorption above a $\mathrm{P}$ intake of approximately $90 \%$ of CVB requirements based on Jongbloed et al. (2003) in growing pigs (20-50 kg, $P=0.11)$ and late finisher pigs $(80-125 \mathrm{~kg}, \mathrm{p}=0.01)$ but not significant in early finisher pigs $(50-80 \mathrm{~kg})$. This decrease would suggest that the use of digestibility coefficients determined at marginal level may overestimate the $\mathrm{P}$ absorption and retention at higher $\mathrm{P}$ intake levels. On the other hand, Ekpe et al. (2002) and Stein et al. (2008) studying the response to incremental levels of $P$ from MCP and DCP, respectively, did not observe a decrease in relative $P$ absorption with incremental $P$ content. The main difference between these studies and our study was that in the latter two studies Ca content was kept constant or increased to a lesser extent than $\mathrm{P}$ content, whereas in our study $\mathrm{Ca}$ and $\mathrm{P}$ were added in a constant ratio of 3.0 , with a minimum Ca content of $5 \mathrm{~g} / \mathrm{kg}$. An increase in Ca content may contribute to a decrease in $\mathrm{P}$ digestibility, e.g. because of the increase in buffer capacity and intestinal $\mathrm{pH}$ and the formation of Ca-phosphate complexes. The effect of $\mathrm{Ca}$ is further addressed in paragraph 4.2. In a review of Létourneau-Montminy et al. (2012) a linear relationship between intake of non-phytate $\mathrm{P}$ and digested $\mathrm{P}$ was observed, without significant quadratic component, over a wide range of NPP from 0.8 to $5.3 \mathrm{~g} / \mathrm{kg}$ of diet. This suggests little effect of an increasing NPP supply on the digestibility and absorption from the digestive tract. In line with these 
results, Symeou et al. (2014b) adopted a constant absorption of non phytate $\mathrm{P}$ of 0.8 from the digestive tract, irrespective of the dietary NPP supply. On the other hand, LétourneauMontminy et al. (2011) modelled the digestion and absorption of NPP (and PP) on the basis of solubilisation and absorption kinetics in relation to digestive transit time in a threecompartment model (stomach, proximal and distal small intestine) based on assumptions regarding the contribution of active and passive absorption. This approach allows to account for effects of the digestive transit of an increasing amount of $P$ in relation to the (in)solubilisation and active and passive absorptive capacity of the gut. However, since the parameters of $\mathrm{Ca}$ and $\mathrm{P}$ absorption used by Létourneau-Montminy et al. (2011) were based on Stein et al. (2008) cited above, the model may not be expected to provide new insight in the effect of NPP intake on P absorption beyond that study. None of the models includes active regulation of $P$ absorption in relation to dietary $P$ supply. In fact, the relative contribution of active and passive transport to the intestinal absorption of $\mathrm{P}$ is unclear and a matter of debate. Montminy-Létourneau et al. (2011) assumed that $P$ is largely absorbed involving active mechanisms, whereas others (Fan et al. 2008; Symeou et al., 2014a) assumed that only at low $\mathrm{P}$ intake a substantial fraction of $\mathrm{P}$ is absorbed by active transport. As a consequence of the latter assumption, $\mathrm{P}$ absorption (\%) is relatively independent of NPP supply, with urinary $P$ as the major route of excretion at incremental levels of dietary $P$ supply.

In the context of this study we conclude that there is insufficient evidence for a decrease in $\mathrm{P}$ absorption with increasing dietary $\mathrm{P}$ supply, and therefore this is not accounted for in the factorial method. However, as discussed above, it cannot be excluded that $\mathrm{P}$ digestion and absorption at levels required for adequate performance and bone mineralisation is less than at levels applied to determine the $\mathrm{P}$ digestibility of feed ingredients. Moreover, the complex dynamics of phytate solubilisation and degradation in relation to phytase and $\mathrm{Ca}$ in the diet have not been addressed as being outside the scope of the study. It is recommended to address these aspects in a response model in the near future.

\subsubsection{Summary}

To calculate $P$ requirements, a constant standardised digestibility of $P$ based on table values of ingredients is used and a constant utilisation of absorbed $\mathrm{P}$ for $\mathrm{P}$ retention of $98 \%$ is adopted.

\subsection{Calcium}

Because of the close connection between $\mathrm{Ca}$ and $\mathrm{P}$, an adequate $\mathrm{Ca}$ supply is required for optimal growth performance, mineral retention and $\mathrm{P}$ utilisation.

\subsubsection{Post-absorptive utilisation}

Limited attention has been paid to the endogenous urinary and faecal losses of $\mathrm{Ca}$ and the utilisation of absorbed $\mathrm{Ca}$ for retention in the body. With regard to urinary losses, it is assumed that when $\mathrm{P}$ and $\mathrm{Ca}$ are well below the requirements, almost all $\mathrm{Ca}$ and $\mathrm{P}$ is reabsorbed by the kidneys (e.g. Vipperman et al., 1974) and hence a value of $2.0 \mathrm{mg} \mathrm{Ca} / \mathrm{kg}$ BW as endogenous urinary loss was adopted by Létourneau-Montminy et al. (2015). In 16-kg 
pigs fed diets limiting in Ca, Létourneau-Montminy et al. (2010) observed an urinary Ca excretion of $60-80 \mathrm{mg} / \mathrm{d}$ ( $5 \mathrm{mg} / \mathrm{kg} \mathrm{BW}$ ). Stein et al. (2011) observed an urinary excretion of $170 \mathrm{mg} \mathrm{Ca} / \mathrm{d}(6 \mathrm{mg} / \mathrm{kg} \mathrm{BW})$ in pigs with a BW of $25-30 \mathrm{~kg}$ fed a diet limiting in Ca. In a balance study of Gonzalez-Vega et al. (2013) pigs of about $20 \mathrm{~kg} \mathrm{BW}$ had a minimum Ca excretion in the urine of approximately $125 \mathrm{mg} / \mathrm{d}(6 \mathrm{mg} / \mathrm{kg} \mathrm{BW})$ at diets that were severely limiting in $\mathrm{Ca}(\mathrm{Ca} / \mathrm{dP}$ from 0.2-0.9) and Gonzalez-Vega (2016b) observed a minimum urinary $\mathrm{Ca}$ excretion of $220 \mathrm{mg} / \mathrm{d}(6 \mathrm{mg} / \mathrm{kg} \mathrm{BW})$ in $35 \mathrm{~kg}$ pigs. Since none of these studies included Ca-free diets, the urine may also contain incompletely utilised absorbed dietary $\mathrm{Ca}$ and hence the values reported above may overestimate basal endogenous urinary losses. Estimates of endogenous losses and post-absorptive utilisation are highly correlated. The relationship between absorbed $\mathrm{Ca}$ and $\mathrm{Ca}$ excreted in urine derived from the study of Gonzalez-Vega et al. (2013) indicate endogenous losses of about $6 \mathrm{mg} / \mathrm{kg} \mathrm{BW}$ and $90-95 \%$ retention (utilisation) of absorbed Ca. Data of Gonzalez-Vega et al. (2016a,b) who determined the response to an increasing $\mathrm{Ca}$ intake at higher $\mathrm{Ca} / \mathrm{dP}$ ratios in $16 \mathrm{~kg}$ and 35 $\mathrm{kg}$ pigs also indicate a retention of approximately $95 \%$ of absorbed $\mathrm{Ca}$ at the lowest intake levels. The utilisation of incrementally absorbed dietary Ca however gradually decreased. The overall retention of absorbed Ca close to maximum Ca retention was $80-90 \%$. Hence, these results suggest a decrease in utilisation of absorbed $\mathrm{Ca}$ with increasing dietary $\mathrm{Ca}$ content and $\mathrm{Ca} / \mathrm{dP}$ ratio. On the other hand, in the study of Bikker et al. (2013) with increasing dietary $\mathrm{Ca}$ and $\mathrm{P}$ content in a constant ratio $(\mathrm{Ca} / \mathrm{dP}$ of 3.0$)$ the digestion of $\mathrm{Ca}$ gradually decreased whereas the utilisation of absorbed $\mathrm{Ca}$ increased to approximately $80 \%$ and $\geq 90 \%$ in pigs receiving $\mathrm{dP}$ at 110 and $130 \%$ of CVB recommendations, respectively. This increase can be explained by the increase in the proportion of absorbed $\mathrm{P}$ retained in bone, thus facilitating a higher Ca retention. Stein et al. (2008) observed an increase in $\mathrm{Ca}$ retention to approximately $90 \%$ of absorbed $\mathrm{Ca}$ with increasing dietary $\mathrm{Ca}$ intake and decreasing $\mathrm{Ca} / \mathrm{dP}$ ratio. These results indicate that utilisation of absorbed $\mathrm{Ca}$ depends on absolute $\mathrm{Ca}$ and $\mathrm{P}$ intake, and $\mathrm{Ca} / \mathrm{dP}$ ratio and may interact with digestion and requirements (body weight). These interactions require further study and quantification. Based on the presented results, we provisionally adopted endogenous urinary Ca losses of $2 \mathrm{mg} / \mathrm{kg} \mathrm{BW}$ and an efficiency of utilisation of $\mathrm{Ca}$ of $98 \%$. We acknowledge that this is a simplified description of the $\mathrm{Ca}$ utilisation which requires more attention in the future.

\subsubsection{Digestion}

The introduction of dietary recommendations based on (apparent or standardized) digestible $\mathrm{Ca}$ is hampered by the lack of quantitative insight in the Ca digestibility of feed ingredients and the complete diet. At present, only a limited number of studies addressed the $\mathrm{Ca}$ digestibility of feed ingredients and no feedstuff table with digestible Ca values is available. The absence of studies on Ca digestibility in feed ingredients can be put in perspective as in many feed ingredients from plant origin the Ca level is very low and does not substantially contribute to the Ca provision of the animal. Only in inorganic Ca-sources, animal products and a limited number of frequently used plant products (e.g. oil seed co-products) a relatively high Ca-level is present. Hence, diets are generally based on total $\mathrm{Ca}$, whereas $\mathrm{Ca}$ digestibility of ingredients may differ substantially. For example, Gonzalez-Vega et al. (2015) determined an apparent Ca digestibility of $58 \%$ for calcium carbonate and $83 \%$ for mono calcium phosphate. The value for calcium carbonate is in line with Stein et al. (2011) but substantially higher than the value of $37 \%$ obtained by Kemme et al. (1995). These differences may be explained, among others, by characteristics of the calcium carbonate in 
these studies, and an influence of phytic acid in the diet, as Kemme et al. (1995) reported a decrease in $\mathrm{Ca}$ digestibility when phytate-P was increased (-6\%-units for $1 \mathrm{~g}$ phytate-P/kg of diet). Moreover, numerous studies reported an increase in Ca digestibility when (microbial) phytase was added to the diet (e.g. Kemme et al., 1995; Létourneau-Montminy et al., 2010; Gonzalez-Vega et al., 2013). The magnitude of this effect seems dependent on the source of Ca (Gonzalez-Vega et al., 2015b). A Ca evaluation system based on digestion and absorption of $\mathrm{Ca}$ is required to adequately account for these effects. At this point, we recommend to improve the feed evaluation by including the dynamics of Ca digestion, absorption and interactions in the digestive tract. This will not only allow more accurate supply of $\mathrm{Ca}$ to the needs of the pigs, but more importantly reduce the risk of suboptimal $\mathrm{P}$ utilisation and bone mineralisation.

In line with the requirements of $\mathrm{P}$, also for $\mathrm{Ca}$ basal endogenous losses need to be taken into account and preferably included in the requirements of the animal. Information on (basal) $\mathrm{Ca}$ losses from the digestive tract is scarce, but some recent studies allow a provisional estimate. Basal endogenous losses of $\mathrm{Ca}$ in the faeces were derived by regression to zero Ca intake in a study of Gonzalez-Vega et al. (2013) as $175 \mathrm{mg} / \mathrm{kg}$ dry matter intake (DMI). Using Ca-free diets, basal Ca losses were reported as 220 and 396 mg/kg DMI (GonzalezVega et al., 2015a), $123 \mathrm{mg} / \mathrm{kg}$ DMl (Gonzalez-Vega et al., 2015b) and $329 \mathrm{mg} / \mathrm{kg}$ (Merriman and Stein, 2016). These studies were conducted in pigs with an initial BW between 15 and $20 \mathrm{~kg}$. From these results we propose a provisional estimate of mean basal endogenous losses of approximately $250 \mathrm{mg} / \mathrm{kg} \mathrm{DMI}$ and $8 \mathrm{mg} / \mathrm{kg}$ BW. The value per $\mathrm{kg}$ DMI can be used to calculated a standardised digestibility of feed ingredients, the value per $\mathrm{kg} \mathrm{BW}$ can be included in the requirements of the pigs.

\subsubsection{Calcium - phosphorus interactions and calcium requirements}

Interactions between calcium and phosphorus

Because of the lack of a digestible Ca system, recommendations for Ca requirements are presently based on total dietary $\mathrm{Ca}$. This requires assumptions regarding the mean dietary Ca digestibility and consideration of interactions in the digestive tract. Despite the fact that an adequate amount of absorbed $\mathrm{Ca}$ is required for bone mineralisation and optimal utilisation of absorbed $\mathrm{P}$, oversupply of $\mathrm{Ca}$ needs to be avoided because of the negative effect of $\mathrm{Ca}$ on digestion and absorption of $\mathrm{P}$. This negative effect of $\mathrm{Ca}$ may be mediated by several mechanisms:

- Ca may increase the buffer capacity of the diet and the chyme in the stomach, thus hampering the $\mathrm{pH}$ drop below $\mathrm{pH} 4$ as required for solubilisation of phytate and optimal activity of several phytase products.

- A high Ca level may stimulate the formation of insoluble Ca-phytate complexes, thus rendering both $\mathrm{P}$ and $\mathrm{Ca}$ unavailable. It is therefore suggested that the negative effect of a high $\mathrm{Ca}$ content may be bigger in diets high in phytate and supplemented with phytase. However, this was not supported by results of Kemme et al. (1995) and a meta-analysis of Létourneau-Montminy et al. (2012) in which the effect of Ca on P digestibility was independent of the phytate and phytase content.

- At the relatively high $\mathrm{pH}$ in the small intestine a high Ca content in the chyme may increase the formation of insoluble Ca-phosphate complexes, thus limiting the absorption of previously solubilised phosphorus from phytate and non-phytate origin. 
The potential negative effect of Ca content was illustrated by Stein et al. (2011) who reported a decrease in $\mathrm{P}$ digestibility from feed materials and mono sodium phosphate from 61 to $46 \%$ when Ca content from Ca carbonate was increased from 4.6 to $9.2 \mathrm{~g} / \mathrm{kg}$ (Ca:dP ratio 1.8 to 3.6). Similarly, Kemme et al. (1995) reported a decrease in digestibility of $P$ from feed ingredients from 31 to $27 \%$ and from 60 to $54 \%$ when Ca content was increased from 2 to 10 $\mathrm{g} / \mathrm{kg}$ by the addition of calcium carbonate, in diets without or with $800 \mathrm{FTU} / \mathrm{kg}$ of microbial phytase. In this study the realised Ca:dP ratio increased from 1.8 to 8.7 and from 1.2 to 4.5 in diets with 0 and 800 FTU/kg, respectively. Reinhart and Mahan (1986) observed a decrease in growth performance and bone ash content when the total $\mathrm{Ca} / \mathrm{P}$ ratio exceeded 1.3 in phytase-free low $\mathrm{P}$ diets (below NRC requirements) and 2.0 in phytase-free high $\mathrm{P}$ diets (above NRC requirements). Qian et al. (1996) observed a decrease in growth performance and bone ash content when the total $\mathrm{Ca} / \mathrm{P}$ ratio exceeded 1.2 (Ca:dP > 2.1-2.3, dCa:dP > 1.6-1.8) in phytase enriched diets. In a review of a large number of digestibility studies, Létourneau-Montminy et al. (2012) reported a linear decrease in P digestibility of $3 \%$ for each $1 \mathrm{~g} / \mathrm{kg}$ increase in dietary $\mathrm{Ca}$ content, without interaction between $\mathrm{Ca}$ and non-phytate $\mathrm{P}$ content. These results indicate that a high $\mathrm{Ca}$ content or $\mathrm{Ca} / \mathrm{P}$ ratio may decrease $\mathrm{P}$ digestion and retention and presumably this negative effect is bigger in diets with a relatively low $\mathrm{P}$ content, as required for optimal $\mathrm{P}$ utilisation. On the other hand, a too low supply of (digestible) Ca may limit $P$ retention as illustrated by Gonzalez-Vega et al. (2016a,b) and Létourneau-Montminy et al. (2010). The latter authors showed that an increase in Ca content reduced $P$ retention in a phytase-free diet and increased $P$ retention in a diet with microbial phytase despite a similar reduction in $\mathrm{P}$ digestibility in the two diets due to the additional $\mathrm{Ca}$ supply. In the phytase enriched diet overall more $\mathrm{P}$ was released and absorbed and could be retained when more sufficient Ca was available for bone mineralisation.

These results indicate that both a low and high $\mathrm{Ca} / \mathrm{P}$ ratio may reduce $\mathrm{P}$ utilisation and bone mineralisation. The minimum ratio is largely determined by the amount of absorbed $\mathrm{Ca}(\mathrm{dCa})$ which requires insight in digestibility of different Ca sources as discussed above. The maximum is determined by the negative effect on digestibility, which is already present at relatively low levels of Ca:dP ratio as illustrated by Kemme et al. (1995) and by Stein et al. (2011) for a Ca:dP ratio above 1.8. Qian et al. (1996) observed a decrease in bone ash above a dCa:dP ratio of 1.6-1.8, which is in good agreement with the Ca/P ratio of 1.55-1.6 in retained body tissue as derived in this report. At a higher dCa:dP ratio, the surplus $\mathrm{Ca}$ is not retained, whereas it may have a negative effect on $\mathrm{P}$ digestibility, thus reducing the actual $\mathrm{P}$ retention. Kemme et al. (1995) observed an increase in $\mathrm{P}$ retention when Ca was increased in a phytase enriched diet until a dCa:dP ratio of 1.6. Some other studies, e.g. Stein et al. (2011), did not observe an increase in $P$ retention above a dCa:dP ratio of 1.3 . This may be related to the dietary $P$ content. At a relatively low $P$ supply, a large proportion of $P$ is retained in soft tissue with a very low $\mathrm{Ca}$ content, thus reducing the $\mathrm{Ca} / \mathrm{P}$ ratio in whole body tissue deposition.

\section{Estimation of calcium requirements}

The value adopted as digestibility of dietary Ca has a major impact on the recalculation of digestible to total (gross) Ca requirement. This is illustrated by the data of Kemme et al. (1995) and Qian et al. (1996) for which a similar dCa:dP of 1.6 was realised at a total Ca:dP of 3.0 and 2.2, respectively, because of major differences in Ca digestibility. Because of lack of information, NRC (2012) pragmatically adopted a ratio between total Ca and standardised digestible $\mathrm{P}$ of 2.15 , assuming a high availability of most inorganic Ca sources. The German 
GfE (2008) adopted an overall Ca utilisation of $70 \%$, including $30 \%$ losses in faeces and urine, resulting in a Ca:dP ratio between 2.3 and 2.4. Jongbloed et al. (2003) adopted a digestibility value of 50 to $60 \%$ without and with phytase, resulting in a mean Ca:dP ratio of 2.8 for weaned pigs and of 3.0 for growing-finishing pigs. From a number of studies in which Ca digestibility was determined, a mean apparent digestibility of $55 \%$ in diets without microbial phytase seems appropriate for growing pigs. This agrees with a standardised digestibility of 58\% for a diet with $7 \mathrm{~g} \mathrm{Ca} / \mathrm{kg}$ and $250 \mathrm{mg}$ endogenous losses $/ \mathrm{kg}$ dry matter. Thus, if no information of digestibility of the diet is available, we propose to use a value of $58 \%$ to estimate the total Ca requirements from the standardised digestible Ca requirements.

\section{Phytase}

A number of studies has shown the beneficial effect of microbial phytase on Ca digestibility, thus reducing the required total $\mathrm{Ca}: \mathrm{dP}$ ratio. The actual increase depends on the efficacy and inclusion level of phytase, and the diet composition, e.g. Ca content, Ca-source, level and source of phytate and content of other cations (e.g. Mg). We recommend to include the contribution of phytase to digestion and absorption of $\mathrm{Ca}$ as a characteristic of the phytase in the feed optimisation programme. At incremental levels of Ca supply, Kemme et al. (1995) observed an increase in Ca absorption ( $\mathrm{g} / \mathrm{d}$ ) of approximately 0.9 relative to the effect of $P$. Letourneau-Montminy (2010) observed a mean increase in absorbed Ca of 0.94 relative to the release of $P$. These results are in good agreement with a meta-analysis of 22 studies by Bikker et al. (2012) reporting an additional absorption of $0.97 \mathrm{~g} \mathrm{P}$ and $0.86 \mathrm{~g} \mathrm{Ca}$ with 500 FTU of microbial phytase. Other studies observed a wide variation in the ratio of extra absorbed $\mathrm{Ca}$ and $\mathrm{P}$ (in $\mathrm{g} \mathrm{dCa} / \mathrm{g} \mathrm{dP}$ ) resulting from phytase addition to the diet, varying from 0.4 in an unsupplemented canola based diet (Gonzalez-Vega et al., 2013), 0.8 in an unsupplemented corn-soy diet (Guggenbuhl et al., 2007) to 2 for CaCO3 and 4 for DCP supplemented diets (Gonzalez-Vega et al., 2015). For practical application, we suggest to use a contribution of microbial phytase of $0.8 \mathrm{~g}$ digestible Ca per $1 \mathrm{~g}$ of digestible $\mathrm{P}$ if no further information of the effect on Ca digestibility is available. This implies that the required dietary digestible Ca content can be reduced by $0.8 \mathrm{~g}$ per $1 \mathrm{~g}$ of digestible $\mathrm{P}$ released by the phytase supplement. For example, when 500 FTU of phytase $X$ is included per $\mathrm{kg}$ of diet, and this supplement is supposed to contribute $0.8 \mathrm{~g}$ of digestible $\mathrm{P}$, we assume that this amount of phytase contributes $0.64 \mathrm{~g}$ of digestible $\mathrm{Ca}$. Hence, the digestible Ca required from other feed ingredients can be reduced by $0.64 \mathrm{~g} / \mathrm{kg}$.

\subsubsection{Summary}

To estimate standardised digestible Ca requirements, we adopted basal endogenous faecal losses of $8 \mathrm{mg} / \mathrm{kg} \mathrm{BW}$, endogenous urinary losses of $2 \mathrm{mg} / \mathrm{kg} \mathrm{BW}$, and a constant utilisation of absorbed $\mathrm{Ca}$ for retention of $98 \%$. The required dietary $\mathrm{Ca}$ content is based on the standardised digestible Ca content of ingredients, using $250 \mathrm{mg} / \mathrm{kg}$ dry matter to calculated standardised digestibility of $\mathrm{Ca}$ from the apparent digestibility. As a default, a mean standardised $\mathrm{Ca}$ digestibility of $58 \%$ was proposed to calculate the required total dietary $\mathrm{Ca}$ content. 


\section{Requirements of phosphorus and calcium of growing pigs}

With the information discussed above, the $\mathrm{Ca}$ and $\mathrm{P}$ requirements for growing pigs can be calculated using maintenance requirements to cover endogenous losses, and retention in body tissues. In summary, digestible $P$ requirements include:

- $6 \mathrm{mg} / \mathrm{kg} \mathrm{BW}$ for faecal endogenous losses;

- $1 \mathrm{mg} / \mathrm{kg}$ BW for urinary endogenous losses;

- Equation 3 to express retained P per kg EBW gain (after differentiation). For practical use this may be simplified to a constant value of $5.32 \mathrm{~g} / \mathrm{kg}$ EBW.

- Factor 0.98 for utilisation of absorbed $\mathrm{P}$ for $\mathrm{P}$ retention;

- Equation 6 for the relationship between EBW and LW. For practical use, a mean value of EBW as $95 \%$ of LW provides a good approximation. When using a growth model (e.g. TMV, INRAporc), the relationship between EBW and LW from the model can be used.

Total Ca requirements can be derived on the basis of:

- Equation 4 to express retained Ca per kg EBW gain (after differentiation). For practical use this can be simplified by using a Ca/P ratio of 1.55 in weaned pigs until $45 \mathrm{~kg} \mathrm{BW}$ and 1.60 for growing-finishing pigs above $45 \mathrm{~kg}$.

- $8 \mathrm{mg} / \mathrm{kg}$ BW for faecal endogenous losses;

- $2 \mathrm{mg} / \mathrm{kg}$ BW for urinary endogenous losses;

- Factor 0.98 for utilisation of absorbed Ca for Ca retention;

- A mean standardised Ca digestibility of $58 \%$, unless other diet specific information is available.

- Basal endogenous losses of $250 \mathrm{mg} / \mathrm{kg} \mathrm{DM}$ to calculate standardised Ca digestibility form apparent $\mathrm{Ca}$ digestibility.

- Inclusion of the effect of microbial phytase, release of $0.8 \mathrm{~g}$ digestible Ca per $1 \mathrm{~g}$ digestible $\mathrm{P}$ unless other diet or phytase specific information is available.

- In addition: a lower dietary $P$ supply will reduce the Ca/P ratio in the body, hence dietary $\mathrm{Ca}$ : $\mathrm{dP}$ ratio should be reduced accordingly. A 10\% reduction in body $\mathrm{P}$ content (from 5.3 to $4.8 \mathrm{~g} / \mathrm{kg}$ ) will reduce the $\mathrm{Ca} / \mathrm{P}$ ratio by approximately 0.05 .

\subsection{Requirements of weaned pigs}

For the calculation of $P$ requirements of weaned pigs Jongbloed et al. (2003) adopted a 6week growth performance of weaned pigs of $470 \mathrm{~g} / \mathrm{d}$ with an intake of $0.76 \mathrm{EW} / \mathrm{d}$ and a feed conversion of $1.62 \mathrm{EW} / \mathrm{kg}$ of gain, based on studies published before 2003. More recent studies conducted at VIC Sterksel (e.g. Bikker et al., 2011a,b and 2012) showed similar overall growth performance, but indicated a more gradual increase in FCR with age. This was included in the dataset. The final BW of $27 \mathrm{~kg}$ after a six week nursery period agrees with the $20 \%$ of best farms at this point according to Bedrijfsvergelijking AgroVision B.V. (2016). In Table 1 a summary of results is presented. In Annex 8 the performance is given on a daily basis and requirements calculated using the allometric functions and the simplified method presented above. The results of the two methods are only slightly different. The 
results indicate a rapid increase in $\mathrm{P}$ and $\mathrm{Ca}$ requirements per day and a gradual decrease in requirements per EW because of an increasing FCR. A STTD of Ca of $60 \%$ was adopted for piglet diets. For practical application, phase 1 diets with $3.8 \mathrm{~g}$ STTD-P and $10.0 \mathrm{~g}$ Ca per EW (6.0 g STTD-Ca) and phase 2 diets with $3.2 \mathrm{~g} \mathrm{dP}$ and $8.5 \mathrm{~g}$ Ca per EW (5.1 g STTD-Ca) would be adequate in week 1-2 and week 3-6 of the nursery period. Because of the high buffering capacity of $\mathrm{Ca}$ and the negative effects on growth performance and $\mathrm{P}$ digestibility, the usage of microbial phytase and concomitant reduction of $\mathrm{Ca}$ content is recommended.

Table 1. Calculated requirements of standardised total tract digestible (STTD) phosphorus (dP) and STTD and total calcium in weaned pigs (dCa en Ca, respectively) based on model assumptions in paragraph 4.3. The results are based on the mean feed intake, body weight (BW), daily gain (ADG) and feed conversion ratio (FCR) in weekly periods after weaning.

\begin{tabular}{|c|c|c|c|c|c|c|c|c|c|c|c|c|c|}
\hline Wk & $\begin{array}{c}\mathrm{Fl}, \\
\mathrm{EW} / \mathrm{d}\end{array}$ & $\begin{array}{c}\text { BW } \\
\mathrm{kg}\end{array}$ & $\begin{array}{c}\text { ADG } \\
\mathrm{g} / \mathrm{d}\end{array}$ & $\begin{array}{c}\text { FCR, } \\
\text { EW/ } \\
\text { kg }\end{array}$ & $\begin{array}{c}\mathrm{dP} \\
\text { maint., } \\
\mathrm{g} / \mathrm{d}\end{array}$ & $\begin{array}{c}\mathrm{dP} \\
\text { gain, } \\
\text { g/d }\end{array}$ & $\begin{array}{l}\mathrm{dP} \\
\text { total } \\
\mathrm{g} / \mathrm{d}\end{array}$ & $\begin{array}{c}\mathrm{dCa} \\
\text { total } \\
\mathrm{g} / \mathrm{d}\end{array}$ & $\begin{array}{l}\mathrm{dCa} \\
/ \mathrm{dP} \\
\end{array}$ & $\begin{array}{l}\mathrm{dP} / \\
\mathrm{EW}\end{array}$ & $\begin{array}{l}\mathrm{dCa} \\
\text { /EW }\end{array}$ & $\begin{array}{l}\mathrm{Ca} / \\
\mathrm{dP}\end{array}$ & $\begin{array}{l}\mathrm{Ca} / \\
\mathrm{EW}\end{array}$ \\
\hline 1 & 0.22 & 8.0 & 160 & 1.36 & 0.06 & 0.82 & 0.88 & 1.36 & 1.55 & 3.97 & 6.15 & 2.58 & 10.25 \\
\hline 2 & 0.42 & 9.7 & 300 & 1.41 & 0.07 & 1.52 & 1.59 & 2.47 & 1.56 & 3.77 & 5.86 & 2.59 & 9.77 \\
\hline 3 & 0.65 & 12.3 & 430 & 1.53 & 0.09 & 2.16 & 2.25 & 3.51 & 1.56 & 3.46 & 5.40 & 2.60 & 9.01 \\
\hline 4 & 0.90 & 15.8 & 540 & 1.65 & 0.11 & 2.76 & 2.87 & 4.50 & 1.57 & 3.20 & 5.02 & 2.61 & 8.37 \\
\hline 5 & 1.13 & 20.0 & 650 & 1.74 & 0.14 & 3.31 & 3.45 & 5.43 & 1.57 & 3.04 & 4.79 & 2.62 & 7.99 \\
\hline 6 & 1.33 & 25.0 & 750 & 1.77 & 0.18 & 3.82 & 3.99 & 6.31 & 1.58 & 3.01 & 4.76 & 2.63 & 7.93 \\
\hline mean & 0.77 & 27.3 & 470 & 1.65 & & & & & & & & & \\
\hline
\end{tabular}

For $\mathrm{Ca}$ a STTD of $60 \%$ was adopted to calculate total $\mathrm{Ca}$ from digestible $\mathrm{Ca}$, assuming that ingredients with a higher Ca digestibility are used in piglet diets.

\subsubsection{Practical application}

It is generally recommended to minimise the buffer capacity of diets for weaned pigs. Since $\mathrm{Ca}$ (limestone) substantially contributes to a high buffer capacity, Jongbloed et al. (2003) recommended to use a maximum Ca content of $8 \mathrm{~g} / \mathrm{kg}$ in weaning diets, meaning that a transient reduction in bone mineralisation is accepted. Based on the variation in mineral retention in different studies we assume that a transient reduction in $\mathrm{P}$ retention of $15 \%$ (i.e. from 5.32 to $4.52 \mathrm{~g} / \mathrm{kg}$ empty body gain) does not compromise performance and health of newly weaned pigs. Because of the reduction in bone mineralisation, the $\mathrm{Ca} / \mathrm{P}$ retention is reduced from 1.55 to 1.48 (paragraph 3.4). Hence, we recommend a diet with a minimum of $3.4 \mathrm{~g} \mathrm{dP}$ and $8.4 \mathrm{~g}$ Ca per EW during the first 14 days post weaning and a diet with $3.2 \mathrm{~g} \mathrm{dP}$ and $8.4 \mathrm{~g}$ Ca per EW thereafter. The total $\mathrm{Ca}$ content can be reduced if Ca sources with a STTD above $60 \%$ are used. Use of phytase is recommended for the release of digestible $P$ and $\mathrm{Ca}$.

\subsection{Requirements of growing finishing pigs}

Daily requirements of $\mathrm{Ca}$ and $\mathrm{P}$ in growing pigs are largely determined by endogenous losses, related to body weight, and tissue deposition of the pigs. The feed conversion ratio plays a crucial role when requirements are expressed per $\mathrm{kg}$ of feed. Jongbloed et al (2003) used feeding schemes developed with TMV (Technisch Model Varkensvoeding) as published in CVB documentation report 26 (Van der Peet-Schwering et al., 1994). However, these schemes are no longer considered representative for present genotypes of pigs. Moreover, 
intact male pigs were not included in this report. Therefore we used recent data of studies comparing intact male, female and castrated pigs at VIC Sterksel to parametrise the TMVmodel and estimate the weekly feed intake and growth performance of the three types of pigs (Van der Peet-Schwering et al., 2012). In the TMV model the principal approach is the distribution of energy intake above maintenance to lipid and protein deposition according to a predefined ratio (marginal ratio) which increases with increasing body weight of the pig, with a genetically determined maximum daily protein deposition (PDmax). For this calculation amino acid supply was assumed to be non-limiting. The mean results of the three types of pigs in this study agree with the daily gain and feed conversion ratio (EW basis) of the best $20 \%$ farms according to Bedrijfsvergelijking AgroVision (2016). The results are summarised in Table 2, details of the assumptions and results are included in Annex 9. The results in Annex 9 indicate an increase in $\mathrm{dP}$ and $\mathrm{dCa}$ requirements (in $\mathrm{g} / \mathrm{d}$ ) until approximately 60-80 $\mathrm{kg} \mathrm{BW}$ and a decrease thereafter, largely following the growth rate of the pigs. Expressed per $\mathrm{kg}$ of feed or EW, $\mathrm{dP}$ and dCa requirements gradually decrease with increasing BW because of the gradual increase in FCR. The higher requirements of $\mathrm{dP}$ per EW in boars compared to female pigs and even more compared to castrated pigs are also largely explained by differences in FCR.

The calculated requirements per EW are higher than in Jongbloed et al. (2003). This is largely caused by the lower (better) feed conversion in the new calculations of approximately 2.65 and $2.75 \mathrm{EW} / \mathrm{kg}$ body gain for females and castrates, whereas earlier recommendations were based on conversions of 2.81-2.99 EW/kg for females and 2.90-3.06 EW/kg for castrates. Growth rate and feed utilisation were especially higher in the grower period according to the results based on recent studies, thus contributing to increased $\mathrm{dP}$ and $\mathrm{dCa}$ requirements per $\mathrm{EW}$ in this period. 
Table 2. Calculated requirements of standardised total tract digestible (STTD) phosphorus (dP) and calcium (dCa) and total calcium in intact and castrated male and female growing finishing pigs using TMV (Technisch Model Varkensvoeding) ${ }^{1}$.

\begin{tabular}{|c|c|c|c|c|c|c|c|c|c|c|c|c|c|c|}
\hline \multirow[b]{2}{*}{ Wk } & \multicolumn{5}{|c|}{ Intact male pigs } & \multicolumn{4}{|c|}{ Castrated male pigs } & \multicolumn{5}{|c|}{ Female pigs } \\
\hline & $\begin{array}{l}\text { Feed, } \\
\text { intake, } \\
\text { EW/d }\end{array}$ & $\begin{array}{c}\text { BW } \\
\text { start, } \\
\text { kg }\end{array}$ & $\begin{array}{l}\mathrm{dP} / \\
\mathrm{EW}\end{array}$ & $\begin{array}{c}\mathrm{dCa} / \\
\mathrm{EW}\end{array}$ & $\begin{array}{l}\mathrm{Ca} / \\
\mathrm{EW}\end{array}$ & $\begin{array}{l}\text { Feed, } \\
\text { intake, } \\
\text { EW/d }\end{array}$ & $\begin{array}{c}\text { BW } \\
\text { start, } \\
\text { kg }\end{array}$ & $\begin{array}{l}\mathrm{dP} / \mathrm{dCa} / \\
\mathrm{EW} \quad \mathrm{EW}\end{array}$ & $\begin{array}{l}\mathrm{Ca} / \\
\mathrm{EW}\end{array}$ & $\begin{array}{l}\text { Feed, } \\
\text { intake, } \\
\text { EW/d }\end{array}$ & $\begin{array}{c}\text { BW } \\
\text { start, } \\
\text { kg }\end{array}$ & $\begin{array}{l}\mathrm{dP} / \\
\mathrm{EW}\end{array}$ & $\begin{array}{c}\mathrm{dCa} / \\
\mathrm{EW}\end{array}$ & $\begin{array}{l}\mathrm{Ca} / \\
\mathrm{EW}\end{array}$ \\
\hline 1 & 1.05 & 24.0 & 2.84 & 4.49 & 7.73 & 1.10 & 24.0 & 3.205 .04 & 8.70 & 1.10 & 24.0 & 2.79 & 4.40 & 7.59 \\
\hline 2 & 1.25 & 27.8 & 3.06 & 4.83 & 8.33 & 1.35 & 28.5 & 3.124 .93 & 8.50 & 1.30 & 27.9 & 2.98 & 4.71 & 8.12 \\
\hline 3 & 1.5 & 32.7 & 2.86 & 4.54 & 7.82 & 1.60 & 33.9 & 2.774 .39 & 7.57 & 1.55 & 32.9 & 2.82 & 4.48 & 7.72 \\
\hline 4 & 1.7 & 38.2 & 2.75 & 4.36 & 7.53 & 1.85 & 39.6 & 2.534 .02 & 6.92 & 1.80 & 38.5 & 2.66 & 4.22 & 7.28 \\
\hline 5 & 1.9 & 44.1 & 2.56 & 4.08 & 7.03 & 2.10 & 45.5 & 2.323 .69 & 6.36 & 2.00 & 44.6 & 2.46 & 3.92 & 6.76 \\
\hline 6 & 2.05 & 50.3 & 2.43 & 3.87 & 6.68 & 2.30 & 51.7 & 2.173 .46 & 5.97 & 2.15 & 50.8 & 2.33 & 3.72 & 6.41 \\
\hline 7 & 2.15 & 56.5 & 2.34 & 3.73 & 6.44 & 2.40 & 57.9 & 2.113 .37 & 5.81 & 2.25 & 57.1 & 2.25 & 3.60 & 6.20 \\
\hline 8 & 2.25 & 62.8 & 2.27 & 3.62 & 6.25 & 2.50 & 64.2 & 2.063 .28 & 5.66 & 2.35 & 63.4 & 2.19 & 3.49 & 6.03 \\
\hline 9 & 2.35 & 69.1 & 2.21 & 3.53 & 6.09 & 2.60 & 70.5 & 1.993 .18 & 5.49 & 2.45 & 69.7 & 2.12 & 3.39 & 5.84 \\
\hline 10 & 2.45 & 75.5 & 2.16 & 3.46 & 5.96 & 2.65 & 76.9 & 1.953 .12 & 5.38 & 2.50 & 76.1 & 2.08 & 3.33 & 5.74 \\
\hline 11 & 2.55 & 81.9 & 2.10 & 3.36 & 5.79 & 2.70 & 83.1 & 1.903 .05 & 5.25 & 2.55 & 82.4 & 2.05 & 3.28 & 5.66 \\
\hline 12 & 2.6 & 88.4 & 2.06 & 3.30 & 5.69 & 2.70 & 89.3 & 1.883 .01 & 5.19 & 2.60 & 88.7 & 2.02 & 3.23 & 5.57 \\
\hline 13 & 2.65 & 94.8 & 2.02 & 3.23 & 5.56 & 2.70 & 95.3 & 1.862 .98 & 5.14 & 2.65 & 94.9 & 1.98 & 3.17 & 5.46 \\
\hline 14 & 2.65 & 101.1 & 1.99 & 3.19 & 5.49 & 2.70 & 101.2 & 1.852 .96 & 5 & 2.65 & 101.1 & 1.96 & 3.13 & 5.40 \\
\hline 15 & 2.65 & 107.3 & 1.97 & 3.15 & 5.43 & 2.70 & 107.0 & 1.842 .94 & 5.07 & 2.65 & 107.2 & 1.94 & 3.10 & 5.35 \\
\hline 16 & 2.65 & 113.3 & 1.95 & 3.12 & 5.39 & 2.70 & 112.7 & 1.832 .93 & 5.05 & 2.65 & 113.1 & 1.93 & 3.08 & 5.31 \\
\hline 17 & 2.65 & 119.2 & 1.94 & 3.10 & 5.35 & 2.70 & 118.3 & 1.832 .92 & 5.04 & 2.65 & 118.9 & 1.92 & 3.06 & 5.28 \\
\hline 18 & 2.65 & 125.0 & 1.93 & 3.08 & 5.32 & 2.70 & 123.9 & 1.832 .92 & 5.03 & 2.65 & 124.7 & 1.91 & 3.05 & 5.26 \\
\hline
\end{tabular}

\subsubsection{Influence of variation in growth performance}

The results of the different types of pigs (intact male, female, castrate) suggest that feed conversion ratio rather than feed intake and growth rate is the major determinant of the $\mathrm{Ca}$ and $P$ requirements per EW. This is confirmed by a simulation of feed intake and feed utilisation in female pigs. A decrease in growth rate from 850 to $770 \mathrm{~g} / \mathrm{d}$ due to a reduction in feed intake of $10 \%$ with little effect on FCR reduced the required $\mathrm{dP}$ and $\mathrm{Ca} / \mathrm{EW}$ by not more than $2 \%$. A similar reduction in growth rate due to a $10 \%$ increase in FCR from 2.65 to 2.92 reduced the required $\mathrm{dP}$ and Ca per EW by $8-10 \%$ in the grower and early finisher phase and by $10-12 \%$ in the late finisher phase. Pigs with this lower growth performance and higher FCR represent $20-40 \%$ of the farms in Bedrijfsvergelijking AgroVision (2016). Hence, the results in Table 2 are directly applicable for the category of best farms in terms of growth performance and can be reduced proportionately in farms with higher FCR. Our approach assumes that the higher FCR is mainly caused by increased energy use for maintenance processes, immune response, higher lipid to protein deposition (lower lean percentage) etc. and excludes feed spillage and poor feed administration as causes of increased FCR.

\subsubsection{Practical application}

Based on the results in Table 2 and Annex 9, we recommend to base standard diets for growing-finishing pigs on requirements for male and female pigs with a mean growth rate of $850 \mathrm{~g} / \mathrm{d}$ and FCR of $2.6 \mathrm{EW} / \mathrm{kg}$ of gain.

- Grower diet (25-45 kg BW): $2.8 \mathrm{~g}$ STTD-P and $7.6 \mathrm{~g} \mathrm{Ca/EW} \mathrm{(4.4} \mathrm{g} \mathrm{STTD-Ca/EW)}$ 
- $\quad$ Early finisher diet (45-70 kg BW): $2.4 \mathrm{~g}$ STTD-P and $6.5 \mathrm{~g} \mathrm{Ca/EW} \mathrm{(3.8} \mathrm{g} \mathrm{STTD-Ca/EW)}$

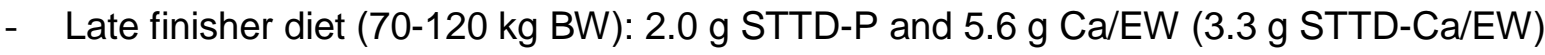
The total Ca content can be reduced if Ca sources with a STTD above $58 \%$ are used. Use of phytase is recommended for the release of digestible $\mathrm{P}$ and $\mathrm{Ca}$.

These levels are adequate for the majority of pigs in the Netherlands and can be reduced for animals with higher FCR, e.g. when raising castrates. The potential reduction is proportional to the increase in FCR as illustrated above in paragraph 5.3 (e.g. a 5\% increase in FCR allows a reduction of $\mathrm{Ca}$ and $\mathrm{P}$ per $\mathrm{EW}$ by $5 \%$ ). 


\section{Requirements of reproductive sows}

\subsection{Introduction}

Phosphorus and calcium requirements of reproductive sows include requirements for maintenance, i.e. to replace endogenous losses, for development of foetuses, uterine contents, and the mammary gland in gestation, for milk production in lactation and for growth and development of the sows. In order to update $\mathrm{Ca}$ and $\mathrm{P}$ recommendations, we largely adopted the factorial approach as described by Jongbloed et al. (2003) using the models for gestating and lactating sows as described by Everts et al. $(1994,1995)$. We verified and extended these models with new insights and data when available and appropriate for the production level of contemporary commercial sows herds as described in Annex 13. In addition, a factorial calculation of calcium requirements has been included.

\subsection{Maintenance}

Maintenance requirements to replace endogenous faecal and urinary $P$ losses have been addressed earlier in this report for both growing pigs and sows (Chapter 2). The values adopted for growing pigs, i.e. $6 \mathrm{P} \mathrm{mg} / \mathrm{kg}$ BW for faecal endogenous losses and $1 \mathrm{mg} \mathrm{P/kg}$ BW for urinary losses are also applied to gestating sows. For lactating sows we adopted a value of $9 \mathrm{mg} / \mathrm{kg}$ BW for faecal endogenous $P$ losses to account for the high feed intake in lactation and the observation that both feed intake and BW influence faecal endogenous losses as discussed in Chapter 2 and Bikker et al. (2016). In addition, we assumed a value of $2 \mathrm{mg} / \mathrm{kg}$ BW for urinary endogenous losses of $\mathrm{Ca}$, and $8 \mathrm{mg} / \mathrm{kg} \mathrm{BW}$ for faecal endogenous losses in gestating sows (see Chapter 4). For lactating sows we adopted a value of $12 \mathrm{mg} / \mathrm{kg}$ BW for faecal endogenous Ca losses, representing an equivalent increase as for endogenous $\mathrm{P}$ losses in lactation.

\subsection{Gestating sows}

In gestating sows $\mathrm{Ca}$ and $\mathrm{P}$ are required for development of products of conception, i.e. foetuses, placenta and fluids and the mammary gland. These are addressed in this paragraph.

\subsubsection{Retention in foetuses}

The development in weight and composition of foetuses, other uterine contents and the mammary gland are largely based on Noblet et al. (1985) and Den Hartog et al. (1988). For P-retention in foetal tissue Jongbloed et al. (2003) based their calculation largely on the serial slaughter study and mineral analysis of foetuses by Den Hartog et al. (1988). The total $P$ retention was as described in the next equation:

$$
\operatorname{Ln} P_{\text {foetus }}(g)=4.591-6.389 \mathrm{e}^{(-0.02398 \times(\mathrm{d}-45)}+0.0897 \times \operatorname{LS}
$$

With:

$\mathrm{P}_{\text {foetus }}=$ the total amount of $\mathrm{P}$ in the foetuses;

$\mathrm{d}=$ day in gestation; 
LS = litter size

The number of studies in which the $\mathrm{P}$ and $\mathrm{Ca}$ content in products of conception during gestation has been determined by serial slaughter of sows is very limited. A dataset including both older and more recent studies in which $\mathrm{P}$ content in foetuses was determined (Figure 7 , left panel) illustrates that the equation based on data of Den Hartog adequately represents the available data in this respect. Nonetheless, the total $P$ content at birth varies substantially between studies. Therefore, in agreement with Jongbloed et al. (2003), for practical application equation S1 is corrected to actual litter birthweight (from Annex 13) and to the actual P-content in new born piglets. The estimate of $\mathrm{P}$ content in newborn piglets has been updated using the available studies as summarised in Annex 10. From these studies we derived a mean content of $5.97 \mathrm{~g} \mathrm{P}$ and $10.50 \mathrm{~g}$ Ca per $\mathrm{kg} \mathrm{BW}$. The correction is made by multiplication of equation S1 on each day of gestation by the ratio between actual and predicted $P$ mass at birth ( $(115)$. The actual $P$ mass is calculated as litter birth weight $x$ mean P content $(5.97 \mathrm{~g} / \mathrm{kg})$ and the predicted P mass as the outcome of equation S1 on $\mathrm{d}$ 115.
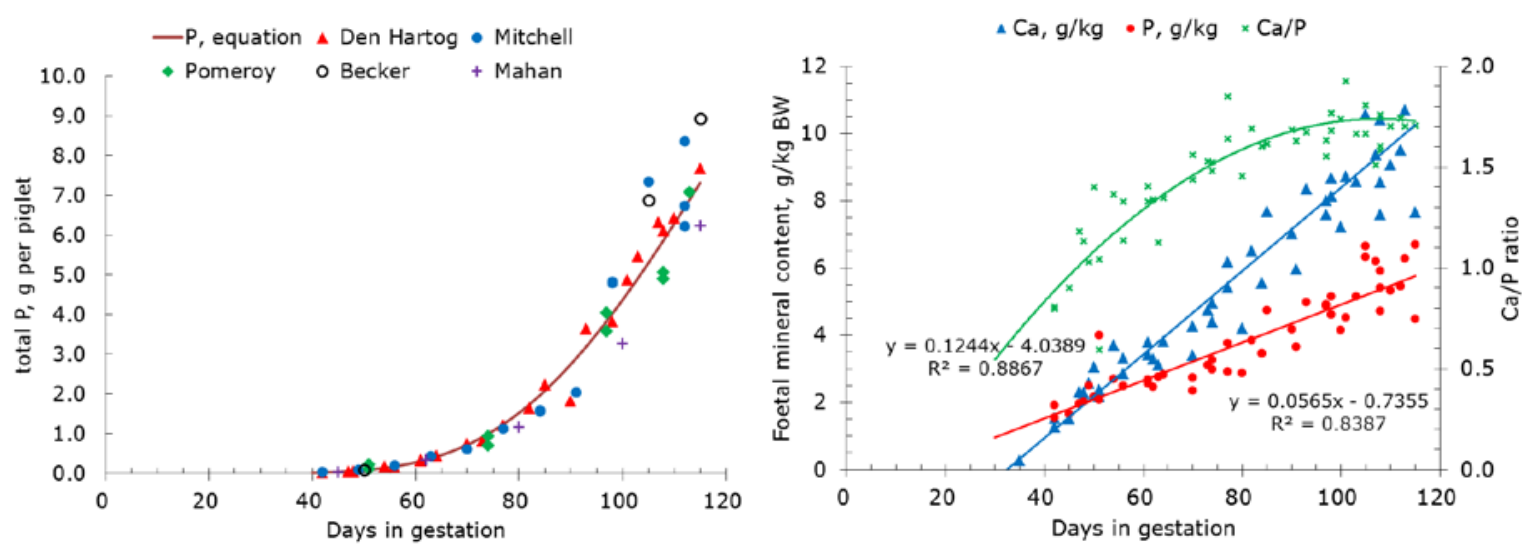

Figure 7. Development of total $\mathrm{P}$ per foetus during gestation according to the equation based on results of Den Hartog et al. (1988) and as observed in other studies (Mitchell, 1931; Pomeroy, 1960; Becker et al., 1979; and Mahan et al., 2009) (left panel) and linear increase in $\mathrm{Ca}$ and $\mathrm{P}$ content expressed per $\mathrm{kg}$ fresh body mass, and resulting $\mathrm{Ca} / \mathrm{P}$ ratio, as derived from the same studies (right panel).

In order to also address the foetal Ca retention, an alternative approach was used. The data from studies in Figure 6 were used to derive the relationships between day of gestation (d) and $\mathrm{P}$ and $\mathrm{Ca}$ content per $\mathrm{kg}$ body weight of growing foetuses. The results were expressed in the equations below and in Figure 6 (right panel):

$$
\begin{aligned}
& P_{\text {foetus }}(\mathrm{g} / \mathrm{kg})=0.0565 \times \mathrm{d}-0.736(\mathrm{R} 2=0.839) \\
& \text { Ca } a_{\text {foetus }}(\mathrm{g} / \mathrm{kg})=0.1244 \times \mathrm{d}-4.039(\mathrm{R} 2=0.887)
\end{aligned}
$$

These equations allow more flexibility than equation S1 as they can be combined with any description of the development of BW of piglets in the uterus, even when derived from studies in which the mineral content of foetuses has not been determined. In addition, this approach allows an estimation of the retention of $\mathrm{Ca}$. As illustrated in Figure 7, the $\mathrm{Ca} / \mathrm{P}$ ratio in foetal tissue increases during the gestation from less than 1 to approximately 1.75 in neonatal pigs. 
We adopted the development of total foetal BW as described with the following equation derived from Noblet et al. (1985). This equation was also used by Everts et al. (1994) in the model for gestating sows:

$$
\text { Ln litter weight }(g)=8.7296-4.0747 \mathrm{e}^{\left(-0.03318^{*}(\mathrm{~d}-45)\right)}+0.00154 \times 30 \times \mathrm{d}+0.0677^{*} \mathrm{LS}
$$

In this equation, the factor "30" represents the mean metabolisable energy intake (ME in $\mathrm{MJ} / \mathrm{d}$ ) in gestation. Since birth weight of piglets is relatively independent of feeding level, provided that sows receive an adequate amount of feed, a fixed value of 30 was used. The result of equation S4 is multiplied by the ratio between actual litter birth weight (e.g. as described in Annex 13) and predicted litter weight at birth (the value of S4 on $d=115$ ) to correct for actual birth weight. The results of combining the equations S2 and S4 closely resemble the development of total $\mathrm{P}$ content in foetuses based on equation $\mathrm{S} 1$, both corrected to actual birth weight and $\mathrm{P}$ contents (Figure 8).
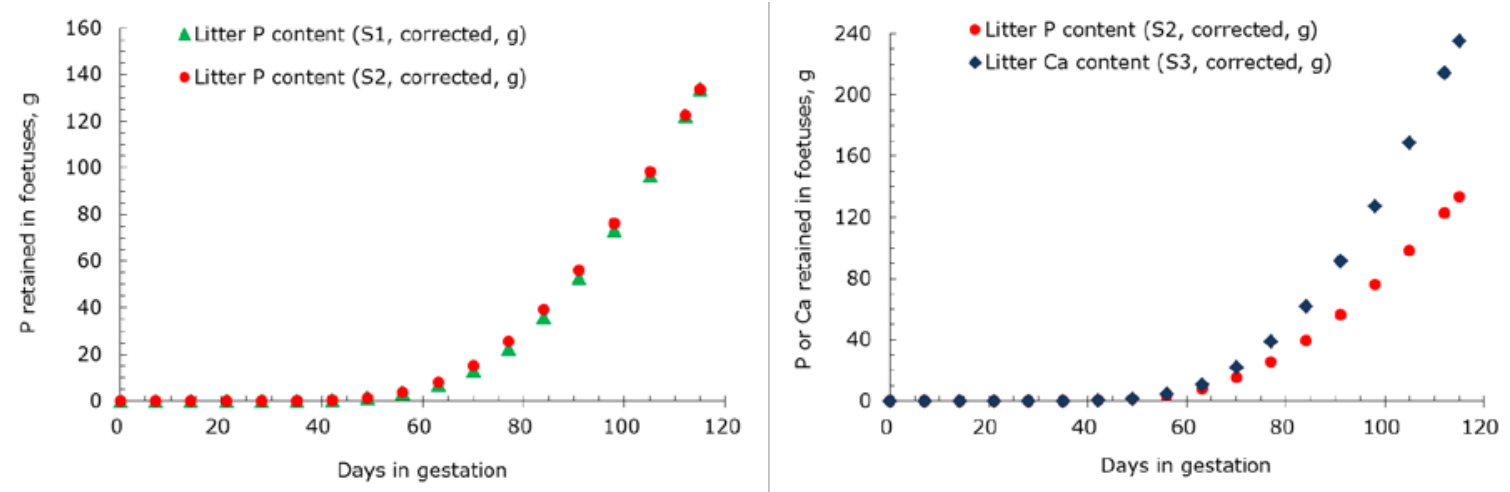

Figure 8. Development of total litter phosphorus $(P)$ during gestation based on equation S1 from Den Hartog et al. (1988) (left) and development of total litter P and calcium (Ca) based on the $\mathrm{P}$ and Ca content ( $\mathrm{g} / \mathrm{kg} \mathrm{BW}$ ) in equation S2 and S3 and development of body weight in equation S4 from Noblet et al. (1985) (left and right panel). Results were scaled to actual birth weight and $\mathrm{Ca}$ and $\mathrm{P}$ content in neonatal pigs.

In summary, to calculate $\mathrm{Ca}$ and $\mathrm{P}$ retention in the foetuses we used the litter development during gestation as described by Noblet et al. (1985)(equation S4), the Ca and P content per $\mathrm{kg}$ BW (equation S2 and S3) as derived from the studies included in Figure 6 and we scaled the results during gestation on the basis of mean $\mathrm{Ca}$ and $\mathrm{P}$ content in piglets at birth and actual litter birth weight from Annex 13. Actual litter birth weight can also be defined by the end-user. In formulas:

(S5) $\quad P_{\text {foetus }}(g)=e^{\text {equation S4 }} \times$ equation S2/1000 $\times$ actual/predicted litter weight $d 115 \times$ 5.97/predicted P-content d115

$\mathrm{Ca}_{\text {foetus }}(\mathrm{g})=\mathrm{e}^{\text {equation } \mathrm{S} 4} \times$ equation $\mathrm{S} 3 / 1000 \times$ actual/predicted litter weight $\mathrm{d} 115 \times$ 10.5/predicted Ca-content d115

In which predicted litter birth weight is the value of equation S4 on d115, actual litter birth weight taken from Annex 13 (defined by the user), 5.97 and 10.50 as the mean $\mathrm{P}$ and $\mathrm{Ca}$ content of newborn piglets and predicted $\mathrm{P}$ and $\mathrm{Ca}$ content at birth as the value of equation S2 and S3 on d115. 


\subsubsection{Retention in other uterine tissues and mammary gland}

Because of the scarcity of information on the development of $P$ retained in the uterus, the placenta and the mammary gland, Jongbloed et al. (2003) related the $P$ content to the protein content of these tissues, using a ratio of $60 \mathrm{~g} \mathrm{P} / \mathrm{kg} \mathrm{N}$ as reported for muscle tissue (Jongbloed, 1987). We largely adopted this approach and assumed a Ca: $\mathrm{N}$ ratio in soft tissue of $4 \mathrm{~g} \mathrm{Ca} / \mathrm{kg} \mathrm{N}$ (Moinizadeh, 1973; Nielsen, 1973; Jongbloed, 1987). However, the study of McPherson et al. (2004) indicates that the mineral (ash) content in the placenta is relatively high (102 g/kg DM), which agrees with observations of Beyer et al. (1994) of 118 $\mathrm{g} / \mathrm{kg} \mathrm{DM}$ and Mitchell et al. (1931) of $143 \mathrm{~g} / \mathrm{kg}$ DM. Mitchell et al. (1931) and Lenkeit (1957) also included measurements of $\mathrm{Ca}, \mathrm{P}$ and $\mathrm{N}$ in the placenta. Based on the combination of these results, we adopted a ratio of $100 \mathrm{~g} \mathrm{P}$ and $80 \mathrm{~g} \mathrm{Ca} / \mathrm{kg} \mathrm{N}$ for placental tissue. From results of Lenkeit (1957) we adopted a ratio of $20 \mathrm{~g} \mathrm{P}$ and $100 \mathrm{~g} \mathrm{Ca} / \mathrm{kg} \mathrm{N}$ for uterine fluids.

The protein in the placenta and uterine fluids was described in the equations derived from Noblet et al. (1985):

$$
\begin{aligned}
& \text { Ln } \operatorname{Pr}_{\text {placenta }}(\mathrm{kJ})=7.3426-1.4060 \mathrm{e}^{(-0.0625 \times(\mathrm{d}-45))}+0.000253 \times 30 \times \mathrm{d}+0.06339 \times \text { LS } \\
& \text { Ln } \mathrm{Pr}_{\text {fluids }}(\mathrm{kJ})=2.3954+0.09807 \times \mathrm{d}-0.000541 \times \mathrm{d}^{2}+0.08734 \times \text { LS }
\end{aligned}
$$

NRC (2012) included recent results of McPherson et al. (2004) and others and derived an equation for the sum of $\mathrm{N}$ in placenta and uterine fluids. Comparison with the equations above for a litter size of 12 pigs did not show any major differences, apart from a steeper increase in the curve described by NRC (2012)(Annex 11). In contrast to Noblet et al. (1985), NRC (2012) did not include litter size in the equation but corrected the weight of the placenta and uterine fluid for actual versus predicted litter weight at birth. Indeed, a positive correlation between placental weight and birth weight is supported by results of Leenhouwers et al. (2002) and Van Rens et al. (2006), therefore we included this correction for weight of placenta and fluids by multiplying equation S7 and S8 with the ratio between actual litter weight (taken from Annex 13) and predicted litter weight (value of equation S4 on d 115) at birth.

$\left(\right.$ S7a) $P$ in placenta $(g)=\left(e^{\text {equation } S 5} /(23.8 \times 6.25 \times 1000)\right) \times 100 \times($ actual $/$ predicted litter birth weight)

(S7b) Ca in placenta $(g)=\left(e^{\text {equation S5 } /(23.8 \times 6.25 \times 1000)}\right) \times 80 \times($ actual/predicted litter birth weight)

with $23.8 \times 6.25 \times 1000$ to calculate $\mathrm{kg} \mathrm{N}$ from kJ protein, 100 and 80 as $\mathrm{g} \mathrm{P}$ and Ca per $\mathrm{kg}$ $\mathrm{N}$, respectively, equation S4 on d 115 for predicted litter birth weight, and actual litter birth weight taken from Annex 13. The latter to be defined by the user.

(S8a) $P$ in fluids $(g)=\left(e^{\text {equation }} \mathrm{s} 6 /(23.8 \times 6.25 \times 1000)\right) \times 20 \times($ actual/predicted litter birth weight)

(S8b) Ca in fluids $(g)=\left(e^{\text {equation S6/ }} /(23.8 \times 6.25 \times 1000)\right) \times 100 \times($ actual/predicted litter birth weight)

with 20 and 100 as $\mathrm{g} P$ and Ca per kg N, respectively. 
In Jongbloed et al. (2003) protein retention in mammary tissue was described by the equation derived from Noblet et al. (1985):

$$
\text { Ln } \operatorname{Pr}_{\text {udder }}(\mathrm{kJ})=1.43401+3.32153 \mathrm{e}^{(0.00991 \times(\mathrm{d}-45))}+0.04803 \times 30
$$

However, comparison with a recent serial slaughter study of Ji et al. $(2005,2006)$ suggests that the mammary protein content of contemporary sows may be substantially higher than predicted by the equation above (Annex 12). Therefore, we adopted the following equation of NRC (2012) to describe the protein content in the mammary gland:

$$
\text { Ln } \operatorname{Pr}_{\text {udder }}(\mathrm{g})=8.4827-7.1786 \mathrm{e}^{\left(-0.0153^{*}(\mathrm{~d}-29.18)\right)}
$$

In agreement with Jongbloed et al. (2003) a P/N ratio of $60 \mathrm{~g} / \mathrm{kg}$ was used for $\mathrm{P}$ content of the mammary gland and we assumed a Ca/ $\mathrm{N}$ ratio of $4 \mathrm{~g} \mathrm{Ca} / \mathrm{kg} \mathrm{N}$ :

$(\mathrm{S} 10 \mathrm{a}) \mathrm{P}$ in udder $(\mathrm{g})=\left(\mathrm{e}^{\text {equation } \mathrm{S} 8} /(23.8 \times 6.25 \times 1000)\right) \times 60$

$(\mathrm{S} 10 \mathrm{~b}) \mathrm{Ca}$ in udder $(\mathrm{g})=\left(\mathrm{e}^{\text {equation } \mathrm{S} 8} /(23.8 \times 6.25 \times 1000)\right) \times 4$

The $\mathrm{P}$ retention in the empty uterus was not separately addressed but considered as part of the maternal gain, in agreement with Everts et al. (1994).

\subsubsection{Maternal mineral retention gain}

Reproductive sows continue to grow, thus depositing maternal soft tissue and bone, during a number of parities. CVB (2012) assumed a maternal gain, excluding uterine contents, of 55 $\mathrm{kg}$ in the $1^{\text {st }}$ gestation, decreasing to $35 \mathrm{~kg}$ in the $5^{\text {th }}$ gestation (Annex 13). Part of this maternal gain is required to replenish mobilised tissue (protein and fat) in the previous lactation, the remainder can be regarded as actual gain of the sows to reach mature body weight. Everts and Dekker (1991) showed that the maternal $P$ retention depends on the $P$ supply in the sow diets. At relatively low and high $\mathrm{P}$ diets, the total maternal P-retention in the first gestation was 75 and $232 \mathrm{~g}$ and the P-content in the maternal body at the end of gestation approximately 4.3 and $5.1 \mathrm{~g} / \mathrm{kg}$ EBW), respectively. This was lower than the Pcontent in the rearing gilt (5.57 g/kg EBW) before mating. The P-content after the $3^{\text {rd }}$ lactation varied between 5.23 and $5.90 \mathrm{~g} / \mathrm{kg} \mathrm{EBW}$, depending on the dietary protein and mineral content. The Ca/P-ratio in these sows after the $3^{\text {rd }}$ lactation varied between 1.71 and 1.77 .

In order to allow for differences in body weight and body gain of sows of different parities, we distinguish between maternal gain required to restore previously mobilised soft tissue and real growth of the sow to reach maturity. In replenishment of soft tissue a P:N ratio of $60 \mathrm{~g} / \mathrm{kg}$ is adopted, in real body gain to reach maturity, a $P$ content of $5.5 \mathrm{~g} / \mathrm{kg}$ empty body gain is adopted. Using this approach, it is not necessary to estimate how much maternal protein is retained in bone, as in Jongbloed et al. (2003). The replenishment of protein $(N)$ in soft tissue in gestation is equal to the adopted mobilisation of body protein in the previous lactation (Annex 13). The real growth is calculated as the difference between total maternal gain and maternal gain required to restore previously mobilised tissue. The target $P$ content of 5.5 $\mathrm{g} / \mathrm{kg}$ EBW is based on results of Everts and Dekker (1991) in which the sows realised a mean P-content of $5.5 \mathrm{~g} / \mathrm{kg}$ EBW after the $3^{\text {rd }}$ lactation. The $P$ content in maternal gain in the first gestation was only $4.1 \mathrm{~g} / \mathrm{kg}$ empty body gain, probably because of the high maternal gain in relation to mineral availability, but this was compensated in later parities. An increase in $\mathrm{P}$ content and $\mathrm{Ca} / \mathrm{P}$ ratio in the body with increasing parity was also observed in a 
longitudinal study over 6 parities by Peters et al. (2010). In this study EBW and Ca and Pcontent in sows at the end of the lactation increased from $172 \mathrm{~kg}, 4.7 \mathrm{~g} \mathrm{P}$ and $7.8 \mathrm{~g} \mathrm{Ca} / \mathrm{kg}$ EBW after the $1^{\text {st }}$ lactation to $244 \mathrm{~kg}$ with $4.9 \mathrm{~g} \mathrm{P}$ and $8.8 \mathrm{~g} \mathrm{Ca} / \mathrm{kg}$ EBW after the $6^{\text {st }}$ lactation. Hence, the increase in total $P$ content was $5.4 \mathrm{~g} / \mathrm{kg}$ empty body weight gain. The results of these studies indicate some flexibility of the sows to adapt $P$ retention in bone to the dietary P-supply and compensate for a marginal supply in earlier parities.

Evert and Dekker (1991) observed a mean Ca/P ratio of 1.75 in the empty body of sows after the $3^{\text {rd }}$ lactation. For the $\mathrm{Ca} / \mathrm{P}$ ratio in maternal gain to reach maturity (real growth) we adopted a value of 1.6 in the $1^{\text {st }}$ gestation and 1.75 in later gestations. The Ca retention in previously mobilised maternal soft tissue was based on the Ca: $\mathrm{N}$ ratio of $4 \mathrm{~g} / \mathrm{kg}$ as discussed in paragraph 6.3.2.

\subsubsection{Digestibility of calcium in sows}

As discussed in more detail for the growing pigs, the digestibility of $\mathrm{Ca}$ and $\mathrm{P}$ plays an important role and has a major impact on the requirements. As indicated by Jongbloed et al. (2003), the observed Ca digestibility in sows varies between about 30 and $55 \%$. For practical reasons, Jongbloed et al. (2003) adopted an apparent Ca digestibility of $48 \%$, although this was substantially higher than observed in studies in the Netherlands. Lower values were reported for Dutch studies compared to studies abroad. In addition, results showed a lower $\mathrm{Ca}$ and $\mathrm{P}$ digestibility in sows compared to growing pigs (Kemme et al., 1997). Indeed, in more recent studies the apparent $\mathrm{Ca}$ digestibility in gestating and lactating sows did not exceed 40\% (Jongbloed et al., 2013, Bikker et al., 2017 in prep.). In line with Jongbloed et al. (2003), we adopted a standardised total tract digestibility of Ca of 50\% (similar to 48\% ATTD of $\mathrm{Ca}$ ) to minimise the negative effects of high $\mathrm{Ca}$ in sow diets. We emphasize that this is at the higher end of results of digestibility studies. More quantitative insight in factors causing this variation is needed to allow avoiding over- or undersupply of minerals.

Similar to growing pigs, the use of microbial phytase would allow a reduction of total dietary $\mathrm{Ca}$ and $\mathrm{P}$ content and is recommended in sows as well. However, the amount of digestible $\mathrm{P}$, and even more digestible $\mathrm{Ca}$, generated by microbial phytase may depend on the physiological state of the pig. The effect of phytase inclusion on Ca digestibility in sows varies between studies with no effect in gestation ( $\mathrm{d} 60$ and d100) and lactation (Kemme et al. 1997a), a positive effect in lactation (Kemme et al. 1997b), a positive effect in late gestation (d100) but not in mid gestation (d70) and lactation (Jongbloed et al. 2013) and a positive effect in lactation (Wealleans et al., 2015). Overall, the use of one value for the liberation of $\mathrm{Ca}$ and $\mathrm{P}$ by phytase, irrespective the physiological state of the pig can be questioned and may result in a suboptimal mineral supply during gestation. We recommend to discuss the efficacy of phytase in gestation and lactation with the supplier of the product. If no specific information is available for practical application, we suggest to use a contribution of microbial phytase of 0.4 and $0.8 \mathrm{~g}$ digestible Ca per $1 \mathrm{~g}$ of digestible $\mathrm{P}$ in diets for gestating and lactating sows, respectively.

\subsubsection{Summary of calculated $\mathrm{Ca}$ and $\mathrm{P}$ requirements}

In summary, the $\mathrm{Ca}$ and $\mathrm{P}$ requirements for retention in the foetuses, placenta, fluids and mammary gland were based on the relation to the protein retention according to equation S6a,b, S7a,b, S8a,b and S10a,b, respectively. Phosphorus and Ca in replenishment of 
previously mobilised maternal tissue were calculated using the ratio of $\mathrm{P}: \mathrm{N}$ and $\mathrm{Ca}: \mathrm{N}$ of 60 and $4 \mathrm{~g} / \mathrm{kg}$, respectively. P-retention in real maternal growth was estimated as $5.5 \mathrm{~g} / \mathrm{kg}$ EBW with a Ca:P ratio of 1.6 in $1^{\text {st }}$ gestation and 1.75 in later gestations.

The results of the calculations based on the equations described above and the description of sows in Annex 13 are included in detail in Annex 14 for gestating sows of parity 1 to 5 . The STTD P and STTD-Ca requirements include basal endogenous losses in the digestive tract. Calcium requirements are also included as total $\mathrm{Ca}$ assuming a STTD of dietary $\mathrm{Ca}$ in gestating sows of $50 \%$. The $P$ requirements in $\mathrm{g} / \mathrm{d}$ and $\mathrm{g} / \mathrm{EW}$ increase gradually until day 63 of gestation and more rapidly thereafter because of the rapid increase in foetal growth and mineral content (Figure 9). The requirements for maternal growth (real gain) are higher in parity 1 sows, whereas $P$ retention in foetuses is higher in multiparous sows because of the higher litter birth weight. In addition, the endogenous P losses increase, due to higher BW of the sows. The net result is a decrease of the $P$ requirements per day and per EW with increasing parity (Figure 9 and Annex 14).

The calculated P-requirements are somewhat higher, approximately $0.5 \mathrm{~g} / \mathrm{d}$ in young sows up to $0.8 \mathrm{~g} / \mathrm{d}$ in late gestating multiparous sows than in Jongbloed et al. (2003). This is the result of combined effects of a higher BW of the sows, slightly higher maternal retention, greater litter size and adoption of an efficiency of utilisation of absorbed $P$ of $98 \%$. Especially the higher $P$ retention in foetuses causes a higher daily $P$ requirement in late gestation. The differences in $\mathrm{P}$ retention in soft tissues due to some revised assumptions only play a minor role. Mean differences in calculated P-requirements per EW between Jongbloed et al. (2003) and this study are relatively small, 0.1-0.2 g/EW higher. The calculated Ca requirements based on a factorial calculation differ more substantially from Jongbloed et al. (2003) who adopted a constant Ca:dP ratio of 3.3 in parity 1-3 sows and 3.5 in higher parities. In the present study, the calculated required dietary $\mathrm{Ca} / \mathrm{dP}$ ratio increase during gestation because of the high $\mathrm{Ca} / \mathrm{P}$ ratio in foetal piglets. e.g. from 3.15 to 3.30 in parity 1 and from 2.8 to 3.2 in parity 5. The mean $\mathrm{Ca} / \mathrm{dP}$ ratio in gestation is approximately 3.15 in parity 1 and 2.8-2.9 in multiparous sows. Hence, overall the Ca requirement are somewhat lower than in Jongbloed et al. (2003).
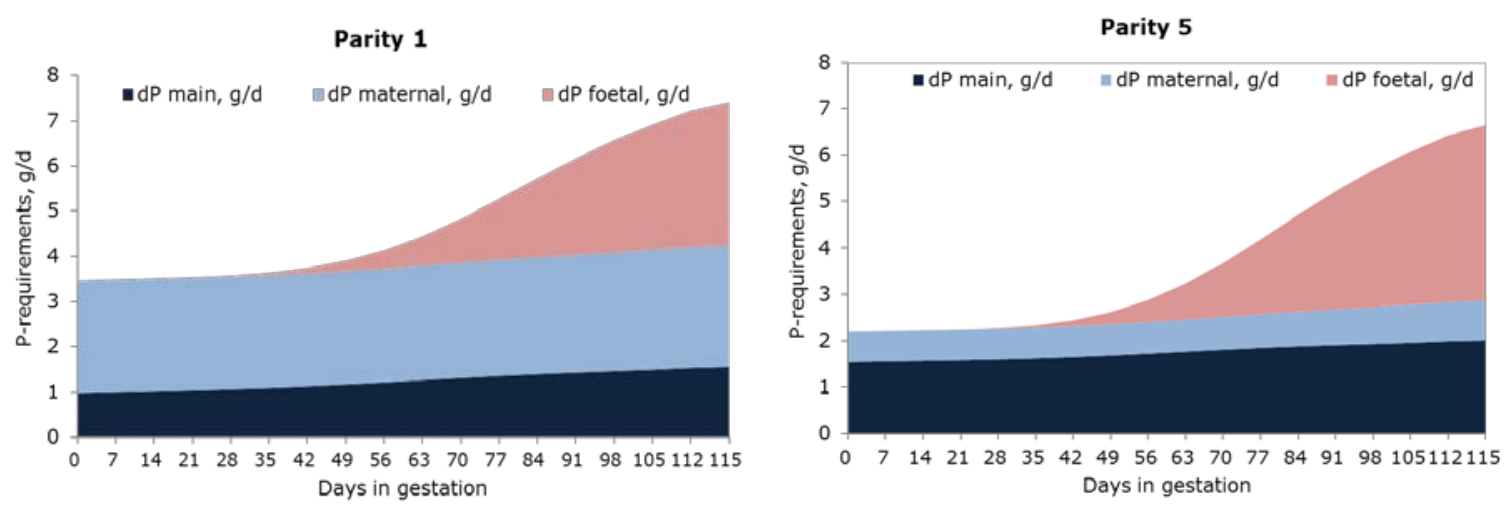

Figure 9. Standardised digestible $P$ requirements for maintenance, i.e. to replace endogenous losses in faeces and urine, and for retention in maternal and foetal tissues during the $1^{\text {st }}$ and $5^{\text {th }}$ parity in gestating sows. 


\subsubsection{Practical application}

The increase in $\mathrm{Ca}$ and $\mathrm{P}$ requirements per day and per EW during gestation may suggest that the diet composition should follow this increase to avoid mineral losses in early gestation and reduced performance in late gestation. However, studies in growing pigs indicate that (soft) tissue deposition and bone mineralisation are to some extent independent processes and that pigs have a certain flexibility to adapt bone mineralisation to the actual $\mathrm{Ca}$ and $\mathrm{P}$ supply in the diet (e.g. Bikker et al., 2013; Letourneau-Montminy et al., 2014). When sows are fed above calculated mineral requirements in early gestation, it is most likely that at least part of the "oversupplied" minerals is used for bone mineralisation. When minerals are supplied marginally below the calculated requirements, this is most likely compensated by a lower bone mineralisation of sows, without loss in foetal growth. Hence, it seems likely that sows can be supplied with a diet with slightly lower $\mathrm{Ca}$ and $\mathrm{P}$ per EW than the values calculated as required in late gestation, provided that the diet is always adequate for maintenance and retention in uterine tissues including the development of foetuses. Over the complete gestation, the diet should be adequate to allow the required maternal gain and bone mineralisation.

For practical application we recommend for the diet of gestating sows:

\begin{tabular}{lccc}
\hline Period & STTP-P, g/EW & STTP-Ca, g/EW & Ca, g/EW \\
\hline Sows until d. 70 of gestation & 1.8 & 2.7 & 5.4 \\
Sows from d. 70 of gestation & 2.4 & 3.9 & 7.8 \\
Complete gestation & 2.2 & 3.5 & 7.0 \\
\hline
\end{tabular}

\subsection{Lactating sows}

\subsubsection{Calcium and phosphorus output in milk}

The $\mathrm{Ca}$ and $\mathrm{P}$ requirements of lactating sows are largely determined by the milk production and output of $\mathrm{Ca}$ and $\mathrm{P}$ in milk, in addition to the maintenance requirements. Jongbloed et al. (2003) based the estimation of the P-output in milk on the requirements for maintenance (7 $\mathrm{mg} / \mathrm{kg} \mathrm{BW}$ ) and tissue deposition in suckling pigs, and a digestibility of $\mathrm{P}$ in milk of $91 \%$. Phosphorus output in milk was based on $\mathrm{P}$ retention in suckling piglets.

In order to determine $\mathrm{Ca}$ and $\mathrm{P}$ output in milk, we compared two methods. Adopting the approach of Jongbloed et al. (2003) we based P- and Ca output in milk on a content of 5.66 $\pm 0.63 \mathrm{~g} \mathrm{P} / \mathrm{kg}$ EBW and $8.71 \pm 1.58 \mathrm{~g} \mathrm{Ca} / \mathrm{kg}$ EBW in piglets weaned between 21 and 34 days of age and a factor of 0.97 for the ratio between EBW and LW (Annex 15). Taking into account the $\mathrm{P}$ and $\mathrm{Ca}$ content in newborn pigs, as discussed in paragraph 6.3.1 (6.0 $\mathrm{g} \mathrm{P}$ and $10.5 \mathrm{~g} \mathrm{Ca} / \mathrm{kg} \mathrm{BW}$ ), the calculated $\mathrm{Ca}$ and $\mathrm{P}$ content in retained tissue in the suckling period is approximately 5.4 and $8.0 \mathrm{~g} / \mathrm{kg} \mathrm{LW}$, respectively. These results have been included in the equations below.

$(\mathrm{S} 11) \mathrm{P}_{\text {milk }}(\mathrm{g} / \mathrm{d})=(($ ADG $\times 5.4+$ mean body weight $\times 0.007) \times \mathrm{LS}) /(0.91 \times 0.98)$

$(\mathrm{S} 12) \mathrm{Ca}_{\text {milk }}(\mathrm{g} / \mathrm{d})=((\mathrm{ADG} \times 8.0+$ mean body weight $\times 0.010) \times \mathrm{LS}) /(0.91 \times 0.98)$

In which ADG is average daily gain from birth to weaning, LS is litter size, mean number of suckling pigs, factors 0.07 and 0.010 represent the endogenous faecal and urinary losses for $\mathrm{P}$ and $\mathrm{Ca}$, respectively, factor 0.91 is the digestibility of $\mathrm{P}$ and $\mathrm{Ca}$ in milk, factor 0.98 is the 
utilisation of $\mathrm{P}$ and $\mathrm{Ca}$. Because of a lack of information, the digestibility of $\mathrm{P}$ was also used for Ca.

This approach assumes that the nutrient composition in milk, especially the $\mathrm{Ca} / \mathrm{P}$ ratio, is optimal to retain all absorbed $\mathrm{P}$ and $\mathrm{Ca}$ in body tissue, without urinary losses. As an alternative approach and validation, we determined the $\mathrm{Ca}$ and $\mathrm{P}$ output in milk based on litter growth rate, milk production derived from litter growth rate according to Everts et al. (1995) and Ca and P-content in milk. Hence, P and Ca output in milk is based on analysis of milk composition and an estimate of the daily milk production. In the model of Everts et al. (1995) the milk production is based on an estimate of energy required for maintenance, protein and lipid retention in the suckling piglets and an estimate of the energy content in milk. The energy content in milk of $5.0 \mathrm{MJ} / \mathrm{kg}$ in this model is supported by the mean value of $4.96 \mathrm{MJ} / \mathrm{kg}$ in a database of a large number of studies published in literature (Jongbloed et al., unpublished data). Based on a review of studies in which milk composition was determined in milk from day 3 in lactation onwards, we adopted as mineral contents in milk $1.46 \mathrm{~g} \mathrm{P}$ and $2.00 \mathrm{~g} \mathrm{Ca}$ per $\mathrm{kg}$ (Annex 16). The estimates of the two methods were in very good agreement for $\mathrm{P}$ requirements. The $\mathrm{P}$ output in milk based on $\mathrm{P}$ retention in piglets (equation S11) was somewhat higher in early lactation and somewhat lower in late lactation then the estimate based on milk production and composition, but overall the difference was small. For example P output in milk was 20.5 and $20.0 \mathrm{~g} / \mathrm{d}$ for the two methods in a $3^{\text {rd }}$ parity sow nursing 14 piglets and a litter growth rate of $3 \mathrm{~kg} / \mathrm{d}$ (see Annex 13 and 18 for details). The estimate for $\mathrm{Ca}$ output in milk based on retention in piglets, however, was approximately $11 \%$ higher than based on milk composition. This may suggest that the digestibility we adopted for $\mathrm{Ca}$ in milk (S12) was not correct and/or the Ca retention in suckling pigs was overestimated. In addition, other reasons may contribute to this discrepancy. Since the milk composition and Ca:P ratio in milk was based on a large number of studies, we used the method based on milk production and composition to calculate the $\mathrm{Ca}$ and $\mathrm{P}$ output in milk and the requirements of the sows.

\subsubsection{Calculation of requirements}

We calculated the requirements for high producing sows described in Annex 13 with 14 suckling piglets and a litter gain of $2.5 \mathrm{~kg} / \mathrm{d}$ for parity 1 and $3.0 \mathrm{~kg} / \mathrm{d}$ for higher parity sows. The daily growth rate of piglets and required milk production was based the model of Everts et al. (1995) and the Ca and P content of milk as discussed above. The total energy requirements of the sow for maintenance and milk production were calculated and corrected with the energy available from tissue mobilisation. Based on the weight loss of the lactating sows (Annex 13), lean and fat tissue mobilisation were calculated and $P$ in lean tissue (60 $\mathrm{g} / \mathrm{kg} \mathrm{N}$ ) was assumed to be available for milk production. The same approach was used for $\mathrm{Ca}$, although the $\mathrm{Ca}$ contribution from lean tissue mobilisation is negligible. The results are presented on a weekly basis and for the complete lactation. The requirements did not include any mobilisation of $\mathrm{Ca}$ and $\mathrm{P}$ from bone tissue. In order to estimate total $\mathrm{Ca}$ requirements we assumed a Ca digestibility of $50 \%$ as discussed for gestating sows in paragraph 6.3.4. Several studies have demonstrated the efficacy of phytase in lactating sows and the use is recommended in lactating sows as well as discussed above (see paragraph 6.3.4).

In Annex 17 the weekly requirements for a $1^{\text {st }}$ parity sows have been presented and in Annex 18 mean requirements in the lactation in relation to parity of the sow. These results indicate that parity of the sow has a limited effect on $\mathrm{Ca}$ and $\mathrm{P}$ requirements per $\mathrm{EW}$, apart from the 
effect mediated by body tissue mobilisation. In Table 3 the effects of litter growth rate and feed intake and tissue mobilisation are illustrated. Without tissue mobilisation, energy and all nutrients need to be ingested via the feed. If the sow is not able to consume this amount of feed, body tissue (muscle and fat) is mobilised and provides amino acids, energy and minerals. However, the amount of $\mathrm{P}$ mobilised from soft tissue is small, thus increasing the required amount of $\mathrm{P}$ per $\mathrm{kg}$ of feed. This effect is even bigger for $\mathrm{Ca}$ since Ca content of soft tissue is negligible. For example, the mobilisation of $1.5 \mathrm{EW} / \mathrm{d}$ in the $2^{\text {nd }}$ parity sows with 3.0 $\mathrm{kg} / \mathrm{d}$ litter gain increases the $P$ requirement from 2.34 to $2.66 \mathrm{~g} / \mathrm{EW}$. In the calculations and recommendations, this effect of tissue mobilisation has been into account. The results in Table 3 demonstrate that the effect of litter growth rate (accounting for effects of the number of piglets and their weaning weight) on $\mathrm{Ca}$ and $\mathrm{P}$ requirements is quite substantial on a daily basis $(\mathrm{g} / \mathrm{d})$, but quite small relative to energy $(\mathrm{g} / \mathrm{EW})$. This is caused by a proportional increase in both minerals and energy.

Table 3. Calculated requirements of a $2^{\text {nd }}$ parity sow with 14 suckling piglets, a litter gain of 2.5 and $3.0 \mathrm{~kg} / \mathrm{d}$, without tissue mobilisation and with tissue mobilisation according to assumptions in Annex 13.

\begin{tabular}{lccccc}
\hline Litter gain, kg/d & 2.5 & & & 3.0 & \\
\cline { 2 - 3 } \cline { 5 - 6 } BW loss in lactation, $\mathrm{kg}$ & 22.5 & 0 & & 22.5 & 0 \\
\hline BW sow after farrowing, $\mathrm{kg}$ & 215 & 215 & & 215 & 215 \\
Energy requirement, EW/d & 7.79 & 7.79 & & 8.84 & 8.84 \\
Energy mobilised, EW/d & 1.48 & 0.00 & & 1.48 & 0.00 \\
Feed intake, EW/d & 6.31 & 7.79 & & 7.36 & 8.84 \\
& & & & & \\
a. P maintenance sow, g/d & 2.04 & 2.15 & & 2.04 & 2.15 \\
b. P based on retention in piglets, g/d & 15.23 & 15.23 & & 18.25 & 18.25 \\
c. P in milk, g/d & 15.37 & 15.37 & & 18.12 & 18.12 \\
d. P from mobilised body tissue, g/d & 0.97 & 0.00 & & 0.97 & 0.00 \\
e. STTD-P requirement in total, g/d (= a+b/0.98-d) & 16.75 & 17.83 & & 19.55 & 20.64 \\
& & & & & \\
f. Ca maintenance sow, g/d & 2.85 & 3.01 & & 2.85 & 3.01 \\
g. Ca in milk, g/d & 21.05 & 21.05 & & 24.82 & 24.82 \\
h. Ca mobilised body tissue, g/d & 0.06 & 0.00 & & 0.06 & 0.00 \\
i. STTD-Ca requirement in total, g/d (=f+g/0.98-h) & 25.01 & 25.17 & & 28.98 & 29.14 \\
& & & & & \\
j. STTD-P req., g/EW intake & 2.65 & 2.29 & & 2.66 & 2.34 \\
k. STTD-Ca req., g/EW intake & 3.96 & 3.23 & & 3.94 & 3.30 \\
I. STTD-Ca/STTD-P (= i/e) & 1.49 & 1.41 & & 1.48 & 1.41 \\
m. Ca requirement, with 50\% STTD of Ca (=i/0.50) & 50.03 & 50.34 & & 57.96 & 58.28 \\
n. Ca requirement, g/EW intake & 7.92 & 6.46 & & 7.88 & 6.60 \\
o. Ca:STTD-P (=m/e) & 2.99 & 2.82 & & 2.96 & 2.82 \\
\hline
\end{tabular}

\subsection{Discussion and practical application}

A direct comparison of the calculated requirements in this study and in Jongbloed et al. (2003) is hampered by differences in assumptions regarding the production level, e.g. body weight of sows, litter size and growth rate. Overall results of our calculations and those of Jongbloed et al. (2003) are not widely different. In our calculations, the use of a factor of 0.98 for utilisation of absorbed $\mathrm{P}$, thus accounting for slightly higher losses via the urine, contributes to a higher estimate of $P$ requirements whereas the use of a slightly lower value for $\mathrm{P}$ output in milk reduces the calculated requirements in comparison to Jongbloed et al. (2003). The intake capacity of the sows and the realised feed intake have a major effect on 
the optimal $\mathrm{Ca}$ and $\mathrm{P}$ content per unit of energy (EW) and need to be taken into account. A low feed intake and high tissue mobilisation increases the requirement of $\mathrm{Ca}$ and $\mathrm{P}$ per unit of energy $(\mathrm{EW})$ and the ratio between digestible $\mathrm{Ca}$ and $\mathrm{P}$. As a result of the introduction of a factorial calculation of the $\mathrm{Ca}$ requirements, the $\mathrm{Ca} / \mathrm{dP}$ ratio varies somewhat between parities, feeding and production level. Overall, the optimal ratio is in good agreement with Jongbloed et al. (2003). The assumed Ca digestibility (STTD of $\mathrm{Ca}$ is 50\%) has a major influence on the required $\mathrm{Ca} / \mathrm{EW}$, whereas the digestible $\mathrm{Ca} / \mathrm{P}$ ratio (approx. 1.4-1.5) is relatively well documented and less variable. Hence, more insight in factors determining the variation in Ca digestibility is required.

For practical application we recommend for the diet of lactating sows:

\begin{tabular}{lccc}
\hline Period & STTP-P, g/EW & STTP-Ca, g/EW & $\mathrm{Ca}, \mathrm{g} / \mathrm{EW}$ \\
\hline Complete lactation & 2.8 & 4.2 & 8.4 \\
\hline
\end{tabular}




\section{References}

ARC, 1967. The nutrient requirements of pigs. Technical review by an agricultural research council working party. Commonwealth Agricultural Bureaux. Slough, England.

Baker, S.R., 2011. Aspects of phosphorus nutrition in swine. Masters Thesis. University of Illinois; Urbana, Illinois, USA.

Becker, K., Farries, E., Pfeffer, E., 1979. Changes in body composition of pig fetuses during pregnancy. Arch. Tierernährng 29, 561-568.

Bedrijfsvergelijking AgroVision, 2016. Kengetallenspiegel januari - december 2015, Deventer, the Netherlands.

Berge, S., Indrebø, T., 1954. Composition of body and weight gain of suckling pigs. Meld. Norg. Landbrug 34, 481-500.

Beyer, M., Jentsch, W., Hoffmann, L., Schiemann, R., Klein, M., 1994. Untersuchungen zum Energie- und Stickstoffumsatz von graviden und lactierenden Sauen sowie von Saugferkeln. 4. Mitteilung - Chemische Zusammensetsung und Energiegehalt der Konzeptionsprodukte, der reproduktiven Organe und der Lebendmassezunahmen oder abnahmen bei graviden und laktierenden Sauen. Arch. Anim. Nutr. 46, 7-36.

Beyga, K., Rekiel, A., 2009. Effect of the backfat thickness of sows in late pregnancy on the composition of colostrum and milk. Arch. Anim. Breeding 52, 593-602.

Bikker, P., Dekker, R.A., Van Diepen, J.Th.M., Van Krimpen, M.M., Jongbloed, A.W., Millet, S., 2013. Behoefte en vastlegging van fosfor bij vleesvarkens. Wageningen UR Livestock Research, rapport 723.

Bikker, P., Jongbloed, A.W., Straathof, B., Binnendijk, G., Van Diepen, J.Th.M., 2011. Copper requirements of growing pigs. Wageningen UR Livestock Research, Confidential Report 301.

Bikker, P., Jongbloed, A.W., Thissen, J.T.N.M., 2012. Meta-analysis of effects of microbial phytase on digestibility and bioavailability of copper and zinc in growing pigs. J. Anim. Sci. 90, suppl. 4, 134-136

Bikker, P., Jongbloed, A.W., Verheijen, R., Binnendijk, G, Diepen, H. van., 2011. Zinc requirements of weaned piglets. Wageningen UR Livestock Research, Confidential Report 274.

Bikker, P., van Laar, H., Sips, V., Walvoort, C. Gerrits, W.J.J., 2016. Basal endogenous phosphorus losses in pigs are affected by both body weight and feeding level. J. Anim. Sci. 94, suppl. 3, 294-297.

Columbus, D., Zhu, C.L., Pluske, J.R., De Lange, C.F.M., 2010. Body weight gain and nutrient utilization in starter pigs that are liquid-fed high moisture corn-based diets supplemented with phytase. Can. J. Anim. Sci. 90, 45-55.

Csapó, J., Martin, T.G., Csapó-Kiss, Z.S., Házas, Z., 1996. Proteins, fats, vitamin and mineral concentrations in porcine colostrum and milk from parturation to 60 days. Int. Dairy J. 6, 881-902.

CVB, 2012. Tabellenboek Veevoeding; voedernormen landbouwhuisdieren en voederwaarde veevoeders. CVB-reeks nr. 50. Productschap Diervoeder Den Haag.

De Wilde, R.O., Jourquin, J., 1992. Estimation of digestible phosphorus requirements in growing-finishing pigs by carcass analysis. J. Anim. Physiol. Anim. Nutr. 68, 218-225. 
Den Hartog, L.A., Zandstra, T., Kemp, B., Verstegen, M.W.A., 1988. Chemical composition of intra uterine tissue and mammary tissue in pigs as related to the stage of pregnancy. J. Anim. Phys. Anim. Nutr. 60, 4-7.

Dilger, R. N., O. Adeola. 2006. Estimation of true phosphorus digestibility and endogenous phosphorus loss in growing pigs fed conventional and low-phytate soybean meals. J. Anim. Sci. 84:627-634.

Ekpe, E.D., Zijlstra, R.T., Patience, J.F., 2002. Digestible phosphorus requirement of grower pigs. Can. J. Anim. Sci. 82, 541-549.

Everts, H., Blok, M.C., Kemp B., Peet-Schwering, C.M.C. van der, Smits, C.H.M., 1994. Normen voor dragende zeugen. CVB-documentatierapport nr. 9. CVB Lelystad The Netherlands, pp 51.

Everts, H., Blok, M.C., Kemp, B., Peet-Schwering, C.M.C. van der, Smits, C.H.M., 1995. Normen voor lacterende zeugen. CVB-documentatierapport nr. 13. CVB Lelystad The Netherlands, pp 45.

Everts, H., Dekker, R.A., 1991. Vermindering van de uitscheiding aan stikstof en fosfor bij fokzeugen door het gebruik van twee verschillende voeders voor dracht en lactatie: resultaten van balans-metingen en vergelijkende slachtproef. IVVO-DLO Rapport no. 230.

Fan, M.Z., Shen, Y., Yin, Y.L., Wang, Z.R., Wang, Z.Y. Li, T.J., Rideout, C., Huang, R.L., Archbold, T., Yang, C.B., and Wang, J., 2008. Methodological considerations for measuring phosphorus utilization in pigs. In: Mathematical Modelling in Animal Nutrition. J. France, and E. Kebreab, eds. CAB Int., Wallingford, Oxon, UK., p. 370-396.

Fandrejewski, H., Rymarz, A., 1986. Effect of feeding level on $\mathrm{Ca}, \mathrm{P}, \mathrm{K}$ and $\mathrm{Na}$ contents in the bodies of growing boars and gilts. Livest. Prod. Sci. 14, 211-215.

Freese, H.H., 1958. Untersuchungen über den Calcium, Phosphor, Magnesium und Stickstoffumsatz des Ferkels in Beziehung zum Wachstum bei Muttermilch und Muttermilchersatz. Arch. Tierernährng 8, 330-392.

GfE, 2008. Recommendations for the supply of energy and nutrients to pigs. DLG Verlag, Frankfurt am Main.

Giesemann, M.A., Lewis, A.J., Miller, P.S., Akhter, M.P., 1998. Effects of the reproductive cycle and age on calcium and phosphorus metabolism and bone integrity of sows. J. Anim. Sci. 76, 796-807

González-Vega, J.C., Liu, Y., McCann, J.C., Walk, C.L., Loor, J.J., Stein, H.H. 2016a. Requirement for digestible calcium by eleven- to twenty-five-kilogram pigs as determined by growth performance, bone ash concentration, calcium and phosphorus balances, and expression of genes involved in transport of calcium in intestinal and kidney cells. J. Anim. Sci. 94, 3321-3334.

González-Vega, J.C., Walk, C.L., Liu, Y., Stein, H.H., 2013. Determination of endogenous intestinal losses of $\mathrm{Ca}$ and true total tract digestibility of calcium in canola meal fed to growing pigs. J. Anim. Sci. 91:4807-4816.

González-Vega, J.C., Walk, C.L., Liu, Y., Stein, H.H., 2014. The site of net absorption of Ca from the intestinal tract of growing pigs and effect of phytic acid, Ca level, and Ca source on Ca digestibility. Arch. Anim. Nutr. 68:126-142.

González-Vega, J.C., Walk, C.L., Murphy, M.R., Stein, H.H. 2016b. Requirement for digestible calcium by 25 to $50 \mathrm{~kg}$ pigs at different dietary concentrations of phosphorus as indicated by growth performance, bone ash concentration, and calcium and phosphorus balances. J. Anim. Sci. 94, 5272-5285. 
González-Vega, J.C., Walk, C.L., Stein, H.H., 2015a. Effect of phytate, microbial phytase, fiber, and soybean oil on calculated values for apparent and standardized total tract digestibility of calcium and apparent total tract digestibility of phosphorus in fish meal fed to growing pigs. J. Anim. Sci. 93:4808-4818.

González-Vega, J.C., Walk, C.L., Stein, H.H., 2015b. Effects of microbial phytase on apparent and standardized total tract digestibility of calcium in calcium supplements fed to growing pigs. J. Anim. Sci. 93:2255-2264.

Guéguen, L., Perez, J.M., 1981. A re-evaluation of recommended dietary allowances of calcium and phosphorus for pigs. Proc. Nutr. Soc. 40:273-278.

Hendriks, W.H., Moughan, P.J., 1993. Whole-body mineral composition of entire-male and female pigs depositing protein at maximal rates. Livest. Prod. Sci. 33, 161-170.

Hill, G.M., Miller, E.R., Ku, P.K., 1983. Effect of dietary zinc levels on mineral concentration in milk. J. Anim. Sci. 57, 123-129.

Ji, F., Hurley, W.L., Kim, S.W., 2006. Characterization of mammary gland development in pregnant gilts. J. Anim. Sci., 84, 579-587.

Ji, F., Wu, G., Blanton, J.R. Jr., and Kim, S.W., 2005. Changes in weight and composition in various tissues of pregnant gilts and their nutritional implications. J. Anim. Sci. 83:366375.

Jondreville C., Dourmad J.Y., 2005. Phosphorus in pig nutrition. Inra Prod. Anim., 18, 183192.

Jondreville, C., Revy, P-S, Dourmad, J-Y, Nys, Y., Hillion, S., Pontrucher, F., Gonzalez, J., Soler, J., Lizardo, R., Tibau, J,. 2004. Influence du sexe et du génotype sur la rétention corporelle de calcium, phosphore, potassium, sodium, magnésium, fer, zinc et cuivre chez le porc de 25 à $135 \mathrm{~kg}$ de poids vif. Journées Recherche Porcine, 36, 17-24.

Jongbloed, A.W., 1987. Phosphorus in the feeding of pigs; effect of diet on the absorption and retention of phosphorus by growing pigs. Rapport IVVO nr. 179, Lelystad, 343 pp.

Jongbloed, A.W., Diepen, J.Th.M. van, Binnendijk, G.P., Bikker, P., Vereecken, M., and Bierman, K., 2013. Efficacy of OptiphosTM phytase on mineral digestibility in diets for breeding sows: Effect during pregnancy and lactation. J. Livest. Sci. 4:7-16.

Jongbloed, A.W., Diepen, J.Th.M. van, Kemme, P.A., 2003. Fosfornormen voor varkens: herziening 2003. CVB-documentatierapport nr. 30.

Jongbloed, A.W., Klop, A., and Barmentloo, A.M. 2002a. De hoeveelheid minderalen en stikstof in biggen vanaf de geboorte tot $25 \mathrm{~kg}$ lichaamsgewicht. Rapport ID-Lelystad no. 2193.

Jongbloed, A.W., Van Diepen, J.Th.M., Bikker, P., Barmentloo, A.M., 2002b. De invloed van het voerniveau op de hoeveelheid stikstof en mineralen in groeiende vleesvarkens. Confidentieel Rapport ID-Lelystad no. 2105.

Jørgensen, H., Fernández, J.A., Just, A., 1986. Aflejring og indhold af mineraler hos slagtesvin. Statens Husdyrbrugsforsøg Meddelelse nr. 621.

Jourquin, J., DeWilde, R.O., 1990. Evaluation of the phosphorus needs in the growing and finishing Belgian crossbred pig. Proc. Intern. Pig Vet. Soc. Congress Lausanne, 344.

Just Nielsen, A. 1973. Anatomical and chemical composition of Danish Landrace pigs slaughtered at 90 kilograms live weight in relation to litter, sex and feed composition. J. Anim. Sci. 36:476-482.

Just Nielsen, A., 1972. Deposition of calcium and phosphorus in growing pigs determined by balance experiments and slaughter Investigations. Acta Agric. Scand. 22, 223-237. 
Just, A., Jørgensen, H., Fernández, J.A., Agergaard, N., 1985. Investigations about the requirements of essential nutrients for growth in ad libitum fed pigs of Danisch Landrace and Large White. 579 Beretning fra Statens Husdyrbrugsforsøg. Copenhagen.

Kemme, P.A., Jongbloed, A.W., Mroz, Z., Beynen, A.C., 1997. The efficacy of Aspergillus niger phytase in rendering phytate phosphorus available for absorption in pigs is influenced by their physiological status. J. Anim. Sci. 75:2129-2138.

Kemme, P.A., Jongbloed, A.W., Mroz, Z., Bruggencate, R. ten, 1995. Effect van het gehalte aan $\mathrm{Ca}$ en microbieel fytase in twee voeders op de $\mathrm{Ca}$-, $\mathrm{Mg}$ - en P-benutting en op de beschikbaarheid van Zn en $\mathrm{Cu}$ bij groeiende varkens. Rapport ID-DLO (vestiging Runderweg) no. 288, 42 pp.

Ketaren, P.P., Batterham, E.S., Dettman, E.B., Farrell, D.J., 1993b. Phosphorus studies in pigs. 2. Assesing phosphorus availability for pigs and rats. Brit. J. Nutr. 70, 269-288.

Ketaren, P.P., Batterham, E.S., Dettman, E.B., Farrell, D.J., 1993c. Phosphorus studies in pigs. 3. Effect of phytase supplemntation on the digestibility and availability of phosphorus in soya-bean meal for grower pigs. Brit. J. Nutr. 70, 289-311.

Ketaren, P.P., Batterham, E.S., White, E., 1993a. Phosphorus studies in pigs. 1. Available phosphorus requirements of grower/finisher pigs. Brit. J. Nutr. 70, 249-268.

Leenhouwers, J.I., Knol, E.F., de Groot, P.N., Vos, H., van der Lende, T., 2002. Fetal development in the pig in relation to genetic merit for piglet survival. J. Anim. Sci. 80, 1759-1770.

Lenkeit, W., 1957. Zum Einfluss der Fütterung auf die Embryonale Entwicklung. Züchtungskunde 29, 397-408.

Létourneau-Montminy, M.P., Jondreville, C., Sauvant, D., Narcy, A., 2012. Meta-analysis of phosphorus utilization by growing pigs: Effect of dietary phosphorus, calcium and exogenous phytase. Animal 6:1590-1600.

Létourneau-Montminy, M.P., Lovatto, P., Pomar, C., 2014. The intestinal absorption of dietary calcium and phosphorus and their efficiency in bone mineral retention are affected by body mineral status in growing pigs. J. Anim. Sci. 92:3914-3924.

Létourneau-Montminy, M.P., Narcy, A., Dourmad, J.Y., Crenshaw, T.D., Pomar, C., 2015. Modelling the metabolic fate of dietary phosphorus and calcium and the dynamics of body ash content in growing pigs J. Anim. Sci. 93, 1200-1217.

Létourneau-Montminy, M.P., Narcy, A., Lescoat, P., Bernier, J.F., Magnin, M., Sauvant, D., Jondreville, C., Pomar, C, . 2011. Modeling the fate of dietary phosphorus in the digestive tract of growing pigs. J. Anim. Sci. 89:3596-3611.

Létourneau-Montminy, M.P., Narcy, A., Magnin, M., Sauvant, D., Bernier, J.F. Pomar, C., Jondreville, C., 2010. Effect of reduced dietary calcium concentration and phytase supplementation on calcium and phosphorus utilization in weanling pigs with modified mineral status. J. Anim. Sci. 88:1706-1717.

Liu, J.B., Cao, S.C., Chen, L., Zhang, H.F. 2016. Effect of dietary phosphorus level on the determination of standardized and true total tract digestibility of phosphorus for growing pigs. J Anim. Feed Sci. and Technol. 215, 117-123.

Lüdke, H., Schöne, F., Geinitz, D., Brys, J., 1990. Untersuchungen zur Phosphorversorgung von Schweinen im Lebendmasseabschnitt 11-38 kg. 2. Der Phosphor-, Kalzium- und Ascheansatz im Skelett- und Weichgewebehomogenat bei P-Unterversorgung und bei Ansatz von zwei verschiedenen Futterphosphaten sowie unterschiedlicher Rationsgestaltung. Arch. Anim. Nutr. 40, 1085-1095. 
Lyberg, K., Andersson, H. K., Simonsson, A. and Lindberg, J.E., 2007. Influence of different phosphorus levels and phytase supplementation in gestation diets on sow performance. J. Anim. Phys. and Nutr. 91, 304-311.

Mahan, D.C., Fetter, A.W., 1982. Dietary calcium and phosphorus levels for reproducing sows. J. Anim. Sci. 54, 285-291.

Mahan, D.C., Shields, R.G., 1998. Macro- and micromineral composition of pigs from birth to 145 kilograms of body weight. J. Anim. Sci. 76, 506-512.

Mahan, D.C., Watts, M.R., St-Pierre, N., 2009. Macro- and micromineral composition of fetal pigs and their accretion rates during fetal development. J. Anim. Sci. 87, 2823-2832.

Manners, M.J., McCrea, M.R., 1963. Changes in the chemical composition of sow-reared piglets during the 1st month of life. Brit. J. Nutr. 17, 495-513.

Maxson, P.F., and Mahan, D.C. 1986. Dietary calcium and phosphorus for lactating swine at high and average production levels. J. Anim. Sci. 1163-1172.

McPherson, R.L., Ji, F., Blanton, J.R., Kim, S.W., 2004. Growth and composition changes of fetal tissues in pigs. J. Anim. Sci. 82, 2534-2540.

Merimann, L.A., Stein, H.H., 2016. Particle size of calcium carbonate does not affect apparent and standardized total tract digestibility of calcium, retention of calcium, or growth performance of growing pigs. J. Anim. Sci. 94, 3844-3850.

Migdal, W., 1993. The content of mineral elements in the milk of sows. Medycyna Weterynaryjna 49, 459-460.

Mitchell, H.H., Carroll, W.E., Hamilton, T.S., Hunt, G.E., 1931. Food requirements of pregnancy in swine. Univ.Illinois Agric. Exp. Station Bulletin 375, 465-504.

Moinizadeh, H.M. 1973. Einfluss unterschiedlicher Energieversorgung auf Mineralstoffansatz und Mineralstoffverteilung im Körper Wachsender Nutztiere. Dissertation Landwirtschaftlichen Fakultät der Georg-August-Universität zu Göttingen.

Mudd, A.J., Smith, W.C., Armstrong, D.G., 1969. The retention of certain minerals in pigs from birth to $90 \mathrm{~kg}$ live weight. J. Agric. Sci. 73, 181-187.

Noblet, J., Close, W.H., Heavens, R.P., Brown, D., 1985. Studies on the energy metabolism of the pregnant sow. 1. Uterus and mammary tissue development. Brit. J. Nutr. 53, 251265.

NRC, 2012. National Research Council. Nutrient requirements of swine. 11th Ed. National Academy Press, Washington, DC.

Peters, J.C., Mahan, D.C., Wiseman, T.G., Fastinger, N.D., 2010. Effect of dietary organic and inorganic micromineral source and level on sow body, liver, colostrum, mature milk, and progeny mineral compositions over six parities. J. Anim. Sci. 88, 626-637.

Pettey, L.A., Cromwell, G.L., Jang, Y.D., Lindemann, M.D. 2015. Estimation of calcium and phosphorus content in growing and finishing pigs; whole empty body components and relative accretion rates. J. Anim. Sci. 93, 158-167.

Pettey, L.A., Cromwell, G.L., Lindemann, M. D., 2006. Estimation of endogenous phosphorus loss in growing and finishing pigs fed semi-purified diets. J. Anim. Sci. 84:618-626.

Pomar, C., Jondreville, C, Dourmad, J-Y, Bernier, J., 2006. Influence du niveau de phosphore des aliments sur les performances zootechniques et la rétention corporelle de calcium, phosphore, potassium, sodium, magnésium, fer et zinc chez le porc de 20 à $100 \mathrm{~kg}$ de poids vif. Journées Recherche Porcine 38, 209-216.

Pomar, C., Kyriazakis, I., Emmans, G.C., Knap, P.W., 2003. Modeling stochasticity: Dealing with populations rather than individual pigs. Journal of Animal Science (E. Suppl.

2):E178-E186. 
Pomeroy, R.W., 1960. Infertility and neonatal mortality in the sow III. Neonatal mortality and foetal development. J. Agric. Sci. 54, 31-56.

Qian, H., Kornegay, E.T., Conner, D.E. Jr., 1996. Adverse effects of wide calcium:phosphorus ratios on supplemental phytase efficacy for weanling pigs fed two dietary phosphorus levels. J. Anim. Sci. 74:1288-1297.

Reinhart, G.A., Mahan D.C., 1986. Effect of various calcium:phosphorus ratios at low and high dietary phosphorus for starter, grower and finishing swine. J. Anim. Sci. 63:457466.

Renaudeau, D., Noblet, J., Dourmad, J.Y., 2003. Effect of ambient temperature on mammary gland metabolism in lactating sows. JAS 81, 217-231.

Rincker, M.J., Hill, G.M., Link, J.E., Meyer, A.M., Rowntree, J.E., 2005. Effects of dietary zinc and iron supplementation on mineral excretion, body composition, and mineral status of nursery pigs. J. Anim. Sci. 83, 2762-2774

Rincker, M.J., Hill, G.M., Rowntree, J.E., 2004. Effects of dietary iron supplementation on growth performance, hematological status, and whole-body mineral sconcentrations of nursery pigs. J. Anim. Sci. 82, 3189-3197.

Rodehutscord, M., Haverkamp, R., Pfeffer, E., 1998. Inevitable losses of phosphorus in pigs, estimated from balance data using diets deficient in phosphorus. Arch. Anim. Nutr. 51:27-38.

Schöne, F., Lüdke, H., Kirchheim, U., 1995. Prüfung von Aspergillus-Niger-Phytase und Futterphosphat an Absetzferkeln; 2. Mitteillung - Gehalt und Ansatz an Eiweis, Fett, Asche, Ca und P im Tierkörper. Arch. Anim. Nutr. 47, 219-228

Schulz, E., Berk, A., Aulrich, K., 1995. Wirkung der P-Versorgung auf die P-Retention und Wachstumsleistung beim Mastschwein. Proc. Soc. Nutr. Physiol. 4, 100.

Seynaeve, M., DeWilde, R., Janssens, G., DeSmet, B., 1996. The influence of dietary salt level on water consumption, farrowing, and reproductive performance of lactating sows. J. Anim. Sci. 74, 1047-1055.

Shields, R.G., Mahan, D.C., Graham, P.L., 1983. Changes in swine body composition from birth to $145 \mathrm{~kg}$. J. Anim. Sci. 57, 43-54.

Stein, H.H., Adeola, O. Cromwell, G.L., Kim, S.W., Mahan, D.C., Miller, P.S., 2011. Concentration of dietary calcium supplied by calcium carbonate does not affect the apparent total tract digestibility of calcium, but reduces digestibility of phosphorus by growing pigs. J. Anim. Sci. 89:2139-2144.

Stein, H.H., Kadzere, C.T. Kim, S.W. and P.S. Miller, P.S., 2008. Influence of dietary phosphorus concentration on the digestibility of phosphorus in monocalcium phosphate by growing pigs. J. Anim. Sci. 86:1861-1867.

Symeou, V., Leinonen, I., Kyriazakis, I., 2014. Modelling phosphorus intake, digestion, retention and excretion in growing and finishing pigs: model description. Animal 8, 16121621.

Symeou, V., Leinonen, I., Kyriazakis, I., 2014. Modelling phosphorus intake, digestion, retention and excretion in growing and finishing pigs: model evaluation. Animal 8, 16221631.

Thomsen, R.N., 1952. Undersøgelser vedr. Svinekroppens sammensaetning og energindhold. Oversigt landøkon. Forsøggslab. Arbejder. Copenhagen. P. 35.

Urbanyi, L., 1952. Beitrage zur Biochemie des Fötallebens. Gestaltung der Körperzusammensetzung von Schweineföten während ihrer Entwicklung. Acta Vet. Acad. Sci. Hung. 2, 27-40. 
Van der Peet, G.F.V., Beers, S., Jongbloed, A.W., 1990. The P availability for pigs of four P sources from Tessenderlo Chemie. Comparison of techniques. IVVO Confidential Report.

Van der Peet-Schwering, C.M.C., Straathof, S.B., Binnendijk, G.P., Diepen, J.T.M. van, 2012. Effect van grondstoffensamenstelling en aminozuurgehalte op technische resultaten van beren, borgen en zeugjes. Wageningen UR Livestock Research, rapport 563.

Van der Peet-Schwering, C.M.C., Vos, H.J.P.M., Van der Peet, G.F.V., Verstegen, M.W.A., Kanis, E., Smits, C.H.M., De Vries, A.G., Lenis, N.P., 1994. Technisch Model Varkensvoeding. Informatiemodel. P1.117.

Van Krimpen, M.M., 2008. Notitie leden klankbordgroep Dier en de commissie Varkenshouderij (PVE)

Van Krimpen, M.M., Kuijken, N., Binnendijk, G.P., 2008. Stikstof- en fosfaatvastlegging in vleesvarkens die brijvoer of droogvoer krijgen. Wageningen UR Animal Sciences Group, vertrouwelijk rapport 121.

Van Rens, B. T. T. M., G. de Koning, R. Bergsma, and T. van der Lende. 2005. Preweaning piglet mortality in relation to placental efficiency. J. Anim. Sci. 83:144-151.

Vipperman, P.E., Jr., Peo E.R., Jr., Cunningham, P.J., 1974. Effect of dietary calcium and phosphorus level upon calcium, phosphorus and nitrogen balance in swine. J. Anim. Sci. 38:758-765.

Walstra, P., 1980. Growth and carcass composition from birth to maturity in relation to feeding level and sex in Dutch landrace pigs. PhD-thesis Landbouwhogeschool Wageningen.

Walz, O.P., Pallauf, J., 1991. Untersuchungen zum Vergleich des Bilanzverfahrens und der Tierkörperanalyse zur Messung des Protein-, Energie- und Mineralstoffansatzes von Aufzuchtferkeln. 3. Retention von Phosphor und Verhältnis Calcium zu Phosphor. J. Anim. Physiol. Anim. Nutr. 65, 53-63.

Wealleans, A.L., Bold, R.M., Dersjant-Li, Y., Awati A., 2015. The addition of a Buttiauxella sp. phytase to lactating sow diets deficient in phosphorus and calcium reduces weight loss and improves nutrient digestibility. J. Anim. Sci. 93, 5283-5290.

Weniger, J.H., Funk, K., 1953. Untersuchungen über den Calcium- und Phosphorgehalt ganzer Schweinerkörper. Archiv. Tierernährung 3, 325-341.

Widdowson, E.M., 1950. Chemical composition of newly born mammals. Nature 166, 626628.

Wiseman, T.C., Mahan, D.C., St.-Pierre, N.R., 2009. Mineral composition of two genetic lines of barrows and gilts from twenty to one hundred twenty-five kilograms of body weight. J. Anim. Sci. 87, 2306-2314. 


\section{Annex 1 References of studies with growing pigs}

Reference and characteristics of studies included in dataset of growing finishing pigs

\begin{tabular}{|c|c|c|c|c|c|c|c|c|c|}
\hline Reference & Year & Recnr & $\begin{array}{c}\text { Pigs, } \\
\text { n }\end{array}$ & $\operatorname{Sex}^{1}$ & $\mathrm{BW}, \mathrm{kg}$ & EBW, kg & $\mathrm{Ca}, \mathrm{g}$ & $P, g$ & $\begin{array}{c}P, \\
\mathrm{~g} / \mathrm{kg} \\
\mathrm{EBW}\end{array}$ \\
\hline Jongb1 & 2002 & 20 & 6 & 3 & 3.8 & 3.7 & 28.0 & 19.5 & 5.2 \\
\hline Walz1 & 1991 & 37 & 8 & * & 5.3 & 5.2 & 53.5 & 27.8 & 5.3 \\
\hline Rincker1 & 2004 & 45 & 5 & 3 & 5.9 & 5.7 & 32.2 & 22.2 & 3.9 \\
\hline Peters1-6 & 2010 & 52 & 32 & 3 & 6.8 & 6.5 & 42.0 & 29.8 & 4.6 \\
\hline Jongb2 & 2002 & 60 & 6 & 3 & 7.0 & 6.7 & 56.3 & 40.4 & 6.0 \\
\hline Everts1,2,3,4 & 1991 & 61 & 16 & 3 & 7.6 & 7.2 & 53.8 & 35.6 & 4.9 \\
\hline Jongb3 & 2002 & 62 & 6 & 3 & 7.7 & 7.2 & 61.7 & 45.2 & 6.2 \\
\hline Shields2 & 1983 & 67 & 8 & 3 & 8.5 & 8.1 & 88.3 & 54.0 & 6.7 \\
\hline Rincker2-4 & 2005 & 72 & 24 & 1 & 8.7 & 8.2 & 61.6 & 37.7 & 4.6 \\
\hline Jongb4 & 2002 & 70 & 6 & 3 & 9.2 & 8.7 & 70.9 & 48.6 & 5.6 \\
\hline Schöne1 & 1995 & 83 & 4 & 3 & 10.4 & 9.3 & 87.8 & 57.0 & 6.1 \\
\hline Lüdke1,4 & 1990 & 92 & 23 & 1 & 11.3 & 10.6 & 105.6 & 69.6 & 6.5 \\
\hline Peet1 & 1990 & 84 & 9 & 3 & 11.4 & 10.8 & 89.0 & 57.3 & 5.3 \\
\hline Jongb5 & 2002 & 89 & 6 & 3 & 11.7 & 11.0 & 91.4 & 59.7 & 5.4 \\
\hline Jongb1-H8.4a & 1987 & 110 & 3 & 1 & 16.2 & 15.4 & 115.2 & 70.0 & 4.5 \\
\hline Rincker2-6 & 2004 & 115 & 30 & 3 & 18.4 & 17.5 & 133.1 & 80.0 & 4.6 \\
\hline Joergensen1 & 1986 & 127 & 3 & 2 & 20.0 & 18.6 & 174.1 & 109.0 & 5.9 \\
\hline Jongb6 & 2002 & 135 & 6 & 3 & 20.4 & 19.8 & 165.7 & 111.0 & 5.6 \\
\hline Shields3 & 1983 & 141 & 8 & 3 & 21.3 & 20.1 & 178.5 & 115.5 & 5.7 \\
\hline JongB1 & 1999 & 151 & 4 & 2 & 21.6 & 20.6 & 151.6 & 107.0 & 5.2 \\
\hline Columbus1 & 2010 & 160 & 12 & 3 & 22.3 & 21.7 & * & 125.8 & 5.8 \\
\hline Walz2,3,4,5 & 1991 & 146 & 32 & * & 22.4 & 20.8 & 198.9 & 102.6 & 4.9 \\
\hline Columbus4 & 2010 & 163 & 12 & 3 & 23.0 & 20.7 & * & 116.4 & 5.6 \\
\hline Columbus3 & 2010 & 162 & 12 & 3 & 23.1 & 20.6 & * & 123.5 & 6.0 \\
\hline Columbus2 & 2010 & 161 & 12 & 3 & 23.2 & 21.1 & * & 119.5 & 5.7 \\
\hline Bikker1 & 2013 & 166 & 6 & 5 & 23.5 & 22.0 & 192.2 & 123.5 & 5.6 \\
\hline Schulz1 & 1995 & 174 & 15 & 3 & 25.0 & 22.3 & & 117.4 & 5.3 \\
\hline Hendriks1 & 1993 & 181 & 5 & 4 & 25.7 & 23.7 & 204.0 & 137.0 & 5.8 \\
\hline Hendriks2 & 1993 & 182 & 5 & 2 & 25.7 & 23.8 & 206.0 & 139.0 & 5.8 \\
\hline Jongbloed-H8.2a & 1987 & 187 & 3 & 2 & 26.3 & 24.8 & 219.0 & 139.0 & 5.6 \\
\hline Schöne4 & 1995 & 198 & 6 & 3 & 29.6 & 27.5 & 273.0 & 145.0 & 5.3 \\
\hline Fandrejewski2 & 1986 & 206 & 12 & 2 & 30.8 & 27.8 & 262.0 & 159.0 & 5.7 \\
\hline Jongbloed-H8.2b & 1987 & 207 & 4 & 2 & 32.7 & 29.4 & 253.0 & 159.1 & 5.4 \\
\hline Fandrejewski1 & 1986 & 202 & 11 & 4 & 33.0 & 30.5 & 288.0 & 169.0 & 5.5 \\
\hline DeWilde2 & 1992 & 214 & 7 & 3 & 36.7 & 34.9 & 270.0 & 191.0 & 5.5 \\
\hline Shields4 & 1983 & 221 & 8 & 3 & 37.1 & 34.8 & 281.2 & 177.6 & 5.1 \\
\hline Lüdke3,6,7 & 1990 & 225 & 24 & 1 & 38.0 & 34.9 & 316.4 & 195.3 & 5.6 \\
\hline Jondreville2C & 2004 & 233 & 8 & 1 & 40.05 & 38.7 & 302.5 & 192.0 & 5.0 \\
\hline Jondreville2F & 2004 & 234 & 8 & 2 & 40.75 & 38.7 & 303.5 & 186.0 & 4.8 \\
\hline JongB2 & 1999 & 254 & 12 & 2 & 46.1 & 42.7 & 308.5 & 213.5 & 5.0 \\
\hline Hendriks3 & 1993 & 256 & 3 & 4 & 47.0 & 44.5 & 334.0 & 229.0 & 5.1 \\
\hline Hendriks4 & 1993 & 257 & 3 & 2 & 47.0 & 42.2 & 298.0 & 201.0 & 4.8 \\
\hline Jongbloed-H8.2c & 1987 & 262 & 4 & 2 & 48.4 & 44.0 & 397.7 & 248.9 & 5.7 \\
\hline Bikker10 & 2013 & 287 & 4 & 4 & 49.6 & 47.7 & 413.1 & 261.6 & 5.5 \\
\hline Jourquin4 & 1990 & 268 & 6 & 3 & 50.0 & 47.5 & * & 227.8 & 4.8 \\
\hline Jourquin5 & 1990 & 269 & 6 & 3 & 50.0 & 47.5 & * & 240.6 & 5.1 \\
\hline Bikker11 & 2013 & 288 & 4 & 2 & 52.1 & 50.7 & 419.4 & 269.0 & 5.3 \\
\hline Bikker8 & 2013 & 284 & 3 & 4 & 52.1 & 50.2 & 356.7 & 241.7 & 4.8 \\
\hline Bikker9 & 2013 & 285 & 3 & 2 & 52.4 & 51.1 & 395.6 & 268.8 & 5.3 \\
\hline Shields5 & 1983 & 275 & 8 & 3 & 55.8 & 53.5 & 418.1 & 273.2 & 5.1 \\
\hline Jondreville3F & 2004 & 293 & 8 & 2 & 58.85 & 56.7 & 410.5 & 281.0 & 5.0 \\
\hline Jondreville3C & 2004 & 292 & 8 & 1 & 61.1 & 56.7 & 421.0 & 292.0 & 5.1 \\
\hline
\end{tabular}




\begin{tabular}{|c|c|c|c|c|c|c|c|c|c|}
\hline Reference & Year & Recnr & $\begin{array}{c}\text { Pigs, } \\
\text { n }\end{array}$ & $\operatorname{Sex}^{1}$ & $\mathrm{BW}, \mathrm{kg}$ & EBW, kg & $\mathrm{Ca}, \mathrm{g}$ & $P, g$ & $\begin{array}{c}\mathrm{P}, \\
\mathrm{g} / \mathrm{kg} \\
\mathrm{EBW}\end{array}$ \\
\hline Hendriks6 & 1993 & 306 & 3 & 2 & 65.3 & 61.8 & 501.0 & 334.0 & 5.4 \\
\hline Hendriks5 & 1993 & 305 & 2 & 4 & 65.7 & 63.2 & 525.0 & 351.0 & 5.6 \\
\hline Shields6 & 1983 & 326 & 8 & 3 & 75.8 & 72.1 & 483.2 & 318.6 & 4.4 \\
\hline Jondreville4F & 2004 & 338 & 8 & 2 & 78.15 & 75.4 & 580.0 & 384.0 & 5.1 \\
\hline Jondreville4C & 2004 & 337 & 8 & 1 & 79.75 & 75.4 & 564.5 & 367.5 & 4.9 \\
\hline Schulz8 & 1995 & 331 & 7 & 3 & 81.4 & 76.9 & * & 393.7 & 5.1 \\
\hline Bikker18 & 2013 & 344 & 3 & 4 & 81.7 & 79.6 & 606.8 & 402.9 & 5.1 \\
\hline Bikker19 & 2013 & 345 & 3 & 2 & 82.0 & 79.4 & 587.9 & 396.4 & 5.0 \\
\hline Schulz9 & 1995 & 332 & 7 & 3 & 82.0 & 77.0 & * & 409.6 & 5.3 \\
\hline Bikker21 & 2013 & 348 & 4 & 2 & 82.3 & 79.5 & 676.3 & 426.8 & 5.4 \\
\hline Bikker20 & 2013 & 347 & 4 & 4 & 83.6 & 81.3 & 777.3 & 471.6 & 5.8 \\
\hline JongB3 & 1999 & 336 & 12 & 2 & 84.5 & 81.1 & 575.7 & 387.5 & 4.8 \\
\hline Hendriks7 & 1993 & 339 & 3 & 4 & 84.9 & 82.3 & 615.0 & 412.0 & 5.0 \\
\hline Hendriks8 & 1993 & 340 & 3 & 2 & 84.9 & 82.0 & 581.0 & 383.0 & 4.7 \\
\hline Joergensen2 & 1986 & 365 & 18 & 2 & 88.4 & 83.7 & 739.5 & 473.6 & 5.7 \\
\hline Just7-12 & 1985 & $388 / 393$ & 36 & 6 & 88.90 & 84.10 & 738.4 & 481.1 & 5.7 \\
\hline Just1-6 & 1985 & $382 / 377$ & 36 & 6 & 89.6 & 84.8 & 735.3 & 478.8 & 5.6 \\
\hline Shields7 & 1983 & 402 & 8 & 3 & 90.1 & 86.8 & 596.8 & 383.7 & 4.4 \\
\hline Fandrejewski3 & 1986 & 360 & 23 & 4 & 92.5 & 87.2 & 895.5 & 511.0 & 5.9 \\
\hline Jourquin8 & 1990 & 410 & 6 & 3 & 95.0 & 90.3 & * & 505.6 & 5.6 \\
\hline Jourquin9 & 1990 & 411 & 6 & 3 & 95.0 & 90.3 & * & 511.9 & 5.7 \\
\hline Fandrejewski4 & 1986 & 409 & 24 & 4 & 95.2 & 90.1 & 925.3 & 513.6 & 5.7 \\
\hline Fandrejewski5 & 1986 & 419 & 23 & 2 & 98.8 & 93.6 & 960.3 & 558.8 & 6.0 \\
\hline Jondreville5F & 2004 & 439 & 8 & 2 & 102.5 & 98.2 & 799.0 & 516.5 & 5.3 \\
\hline Jongbloed-H8.2e & 1987 & 444 & 12 & 1 & 102.7 & 96.8 & 842.5 & 515.2 & 5.3 \\
\hline Fandrejewski6 & 1986 & 447 & 24 & 2 & 103.7 & 97.9 & 976.1 & 575.7 & 5.9 \\
\hline Pomar5 & 2006 & 435 & 10 & 1 & 104.1 & 99.3 & 1063.0 & 537.1 & 5.4 \\
\hline Jongb1-H8.4c & 1987 & 450 & 3 & 4 & 104.3 & 94.9 & 726.8 & 461.5 & 4.9 \\
\hline Jongb1-H8.4d & 1987 & 451 & 4 & 4 & 104.6 & 95.3 & 860.8 & 531.7 & 5.6 \\
\hline JongB4 & 1999 & 448 & 8 & 2 & 104.7 & 100.7 & 815.6 & 528.0 & 5.2 \\
\hline Jongb1-H8.4b & 1987 & 449 & 4 & 4 & 105.1 & 94.8 & 750.0 & 481.8 & 5.1 \\
\hline Schulz2 & 1995 & 455 & 8 & 3 & 105.1 & 100.1 & 861.8 & 542.5 & 5.4 \\
\hline Schulz3 & 1995 & 456 & 7 & 3 & 105.1 & 100.0 & 872.6 & 535.6 & 5.4 \\
\hline Jondreville5C & 2004 & 438 & 8 & 1 & 106 & 98.2 & 735.5 & 472.5 & 4.8 \\
\hline Pomar4 & 2006 & 434 & 9 & 1 & 106.2 & 101.2 & 1010.0 & 510.2 & 5.0 \\
\hline Jongb1-H8.4e & 1987 & 452 & 4 & 4 & 106.4 & 94.9 & 721.3 & 466.9 & 4.9 \\
\hline Shields8 & 1983 & 457 & 8 & 3 & 106.8 & 101.6 & 738.3 & 462.3 & 4.6 \\
\hline VanKrimpen1 & 2008 & 473 & 6 & 3 & 107.1 & 101.7 & * & 555.0 & 5.5 \\
\hline Hendriks10 & 1993 & 463 & 4 & 2 & 108.7 & 106.3 & 819.0 & 494.0 & 4.6 \\
\hline Hendriks9 & 1993 & 462 & 4 & 4 & 108.7 & 106.0 & 756.0 & 471.0 & 4.4 \\
\hline VanKrimpen2 & 2008 & 474 & 6 & 3 & 114.7 & 109.0 & * & 502.6 & 4.6 \\
\hline VanKrimpen1 & 2008 & 475 & 14 & 3 & 115.6 & 109.8 & * & 596.1 & 5.4 \\
\hline VanKrimpen2 & 2008 & 476 & 10 & 3 & 116.9 & 111.1 & * & 561.9 & 5.1 \\
\hline Jondreville6F & 2004 & 488 & 8 & 2 & 118 & 115.0 & 1017.0 & 658.5 & 5.7 \\
\hline Jondreville6C & 2004 & 487 & 8 & 1 & 122 & 115.0 & 988.5 & 618.5 & 5.4 \\
\hline Bikker29 & 2013 & 497 & 4 & 2 & 124.8 & 121.2 & 1036.0 & 638.6 & 5.3 \\
\hline Bikker30 & 2013 & 499 & 4 & 4 & 125.3 & 122.5 & 1127.1 & 698.3 & 5.7 \\
\hline Bikker31 & 2013 & 500 & 4 & 2 & 126.0 & 122.2 & 1148.6 & 685.5 & 5.6 \\
\hline Bikker28 & 2013 & 496 & 4 & 4 & 126.1 & 122.3 & 1055.0 & 647.9 & 5.3 \\
\hline Shields9 & 1983 & 490 & 8 & 3 & 127.4 & 124.1 & 878.5 & 537.2 & 4.3 \\
\hline Jondreville7F & 2004 & 503 & 8 & 2 & 133.5 & 126.0 & 1082.0 & 728.5 & 5.8 \\
\hline Jondreville7C & 2004 & 502 & 8 & 1 & 134 & 126.0 & 1060.5 & 697.0 & 5.5 \\
\hline
\end{tabular}

Sex 1 = castrate, 2 = female, $3=$ castrate and female, $4=$ male, $5=$ male and female 


\section{Annex 2 Characteristics of studies with growing pigs}

Summary of characteristics of studies published since 1985 in which P content in the empty was determined, and the same dataset after exclusion of studies with dietary P-supply below CVB recommendations.

Descriptive statistics of the dataset of growing-finishing pigs with all publications since 1985

\begin{tabular}{llllllr}
\hline & $\mathrm{N}$ & \multicolumn{1}{c}{ Min } & \multicolumn{1}{c}{ Max } & \multicolumn{1}{c}{ mean } & median & SD \\
\hline BW, kg & 130 & 3.8 & 134 & 63.9 & 60.0 & 38.9 \\
EBW, \% & 130 & 89.2 & 98.3 & 94.4 & 94.8 & 2.10 \\
CP, g/kg EBW & 113 & 126 & 199 & 160.1 & 161.5 & 12.8 \\
Fat, g/kg EBW & 108 & 65.0 & 394.8 & 168.1 & 155.4 & 62.3 \\
Ash, g/kg EBW & 109 & 18.8 & 36.8 & 28.6 & 29.3 & 3.95 \\
Ca, g/kg EBW & 109 & 4.32 & 10.90 & 7.80 & 7.84 & 1.48 \\
$\mathrm{P}, \mathrm{g} / \mathrm{kg} \mathrm{EBW}$ & 130 & 3.21 & 6.67 & 5.05 & 5.15 & 0.69 \\
$\mathrm{Ca} / \mathrm{P}$ & 109 & 1.18 & 1.98 & 1.54 & 1.54 & 0.15 \\
\hline
\end{tabular}

Descriptive statistics of the dataset of growing-finishing pigs with publications since 1985, used for analysis of body $\mathrm{P}$ and $\mathrm{Ca}$ content in relation to empty body weight in the present study ${ }^{1)}$.

\begin{tabular}{lllllll}
\hline & $\mathrm{N}$ & \multicolumn{1}{c}{ Min } & \multicolumn{1}{c}{ Max } & mean & median & SD \\
\hline BW, kg & 104 & 3.8 & 134 & 64.3 & 63.2 & 40.0 \\
EBW, \% & 104 & 89.2 & 98.3 & 94.6 & 95.0 & 2.21 \\
$\mathrm{CP}, \mathrm{g} / \mathrm{kg} \mathrm{EBW}$ & 92 & 135 & 199 & 162.8 & 164.0 & 10.7 \\
Fat, g/kg EBW & 87 & 65.0 & 394.8 & 167.6 & 153.2 & 63.0 \\
Ash, g/kg EBW & 89 & 23.1 & 36.8 & 29.9 & 29.9 & 2.94 \\
$\mathrm{Ca}, \mathrm{g} / \mathrm{kg}$ EBW & 89 & 5.69 & 10.90 & 8.34 & 8.31 & 1.03 \\
$\mathrm{P}, \mathrm{g} / \mathrm{kg}$ EBW & 104 & 3.92 & 6.67 & 5.32 & 5.32 & 0.48 \\
$\mathrm{Ca} / \mathrm{P}$ & 90 & 1.37 & 1.98 & 1.58 & 1.56 & 0.12 \\
\hline
\end{tabular}

1) The series of three studies of Ketaren et al. (1993a,b,c) was not included since the body P content was expressed in dry matter whereas dry matter content itself was not provided. The extensive dataset of Wiseman et al. (2009) was not included since the calculated digestible P content of the diets was increasingly below the CVB-recommendations, which may explain the P content at a BW of 20 to $125 \mathrm{~kg}$ being consistently less than $4 \mathrm{~g} \mathrm{P} / \mathrm{kg}$ EBW. The extensive dataset of Pettey et al. (2004, 2015) was excluded since the diets were marginal according to CVB standards. This was substantiated by the low $\mathrm{Ca} / \mathrm{P}$ ratio in the empty body (1.2-1.4) as an indication of a low dietary Ca or P supply. 


\section{Annex 3 Year of publication and P and Ca content}

Relationship between year of publication and $\mathrm{P}$ and $\mathrm{Ca}$ content in the empty body of growing pigs determined in the dataset of studies published since 1985.
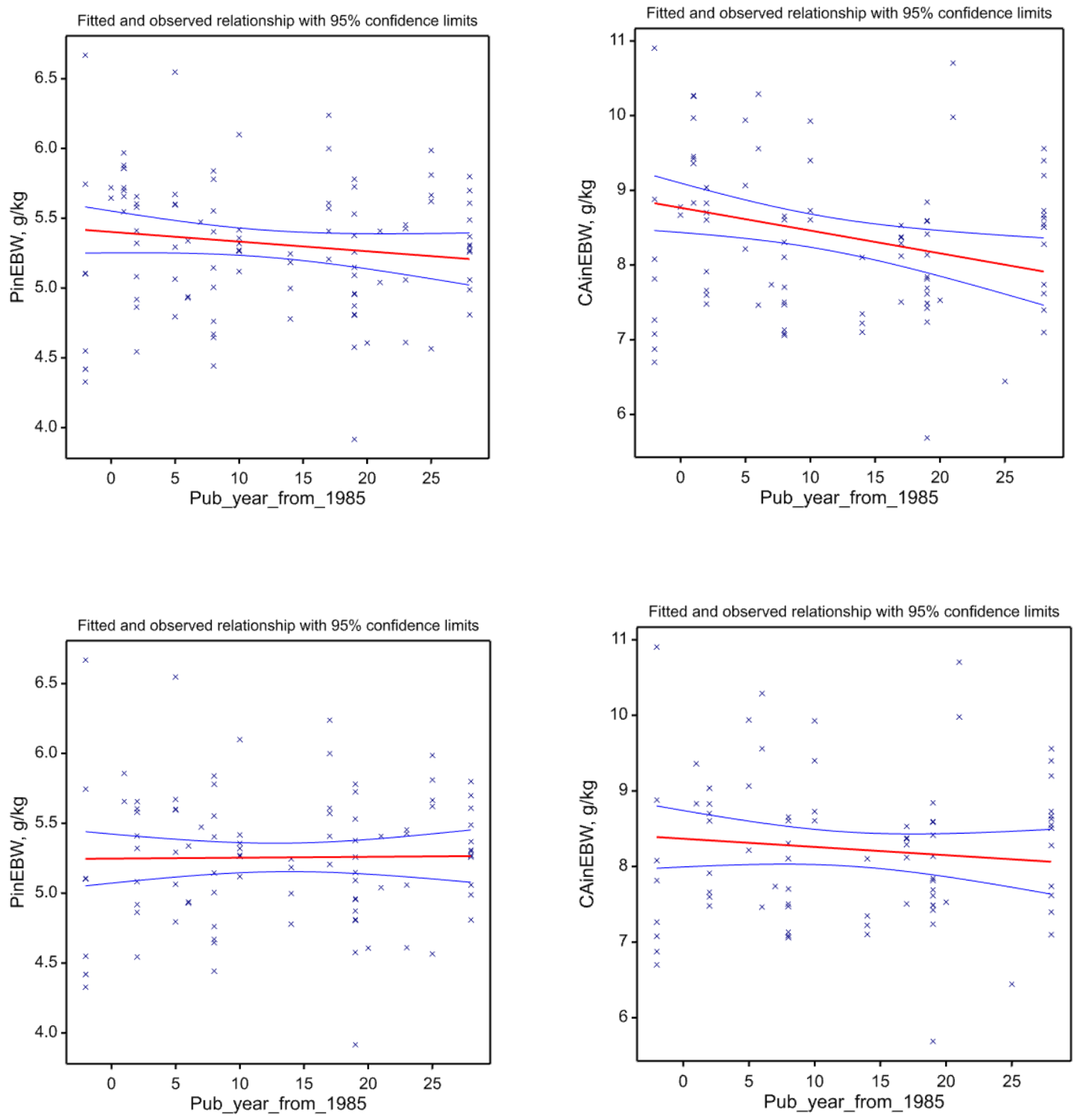

Relationship between year of publication, relative to 1985 and phosphorus $(P)$ and calcium (Ca) content in the empty body ( $\mathrm{g} / \mathrm{kg}$ EBW). The upper panel includes the complete dataset, whereas in the lower panel the data of Fandrejewsky et al. (1986) and Just et al. (1985) have been removed. The relationships in the upper and lower panel, respectively, were:

$P=5.40 \pm 0.076-0.0069 \pm 0.0050 \times(P=0.165)$ and $\mathrm{Ca}=8.77 \pm 0.17-0.031 \pm 0.0115 X$ $(P=0.009)$

$P=5.25 \pm 0.088-0.00063 \pm 0.0054 X(P=0.907)$ and $\mathrm{Ca}=8.37 \pm 0.19-0.011 \pm 0.0119 X$ $(P=0.364)$ 


\section{Annex 4 Prediction equations for body $\mathrm{P}$ and $\mathrm{Ca}$}

Linear, quadratic and logistic relationships between $\mathrm{P}$ and Ca content $(\mathrm{g})$ and their ratio in the empty body of pigs as dependent variables and the empty body weight (EBW, $\mathrm{kg}$ ), or body nitrogen mass $(\mathrm{N}, \mathrm{kg}$ ) as independent variables in the dataset of studies published since 1985. In addition relationships between EBW and live weight (LW) are included.

\begin{tabular}{|c|c|c|c|c|c|c|c|c|c|c|}
\hline $\mathrm{N}$ & $\mathrm{Y}$ & $\mathrm{X}$ & Int. & $\mathrm{P}$ & $a x$ & $P$ & $\mathrm{bX} 2$ & $P$ & R2 & SE \\
\hline \multirow[t]{4}{*}{104} & $P, g$ & EBW & - & - & $\begin{array}{r}5.33 \\
\pm 0.043 \\
\end{array}$ & $<0.001$ & - & - & 97.7 & 54.1 \\
\hline & & & $\begin{array}{r}0.48 \\
\pm 5.84 \\
\end{array}$ & 0.935 & $\begin{array}{r}5.32 \\
\pm 0.081 \\
\end{array}$ & $<0.001$ & - & - & 97.7 & 54.3 \\
\hline & & & - & - & $\begin{array}{r}5.35 \\
\pm 0.189 \\
\end{array}$ & $<0.001$ & $\begin{array}{r}-0.00024 \\
\pm 0.0019 \\
\end{array}$ & 0.902 & 97.7 & 54.3 \\
\hline & & & $\begin{array}{r}-0.10 \\
\pm 8.62 \\
\end{array}$ & 0.991 & $\begin{array}{r}5.36 \\
\pm 0.36 \\
\end{array}$ & $<0.001$ & $\begin{array}{r}-0.00027 \\
\pm 0.0029\end{array}$ & 0.927 & 97.6 & 54.6 \\
\hline \multirow[t]{4}{*}{92} & $P, g$ & $\mathrm{~N}, \mathrm{~kg}$ & - & - & $\begin{array}{l}203.2 \\
\pm 1.73\end{array}$ & $<0.001$ & - & - & 97.6 & 55.1 \\
\hline & & & $\begin{array}{r}0.15 \\
\pm 6.40 \\
\end{array}$ & 0.981 & $\begin{array}{l}203.1 \\
\pm 3.35 \\
\end{array}$ & $<0.001$ & - & - & 97.6 & 55.4 \\
\hline & & & - & - & $\begin{array}{l}197.5 \\
\pm 8.13\end{array}$ & $<0.001$ & $\begin{array}{r}2.29 \\
\pm 3.20 \\
\end{array}$ & 0.477 & 97.6 & 55.2 \\
\hline & & & $\begin{array}{r}8.17 \\
\pm 9.66 \\
\end{array}$ & 0.400 & $\begin{array}{l}186.2 \\
\pm 15.6 \\
\end{array}$ & $<0.001$ & $\begin{array}{r}5.36 \\
+4.85 \\
\end{array}$ & 0.272 & 97.6 & 55.3 \\
\hline 104 & LnP & $\begin{array}{l}\text { Ln } \\
\text { EBW }\end{array}$ & $\begin{array}{r}1.6697 \\
\pm 0.0388 \\
\end{array}$ & $<0.001$ & $\begin{array}{l}1.00040 \\
\pm 0.0099\end{array}$ & $<0.001$ & - & - & 99.0 & 0.163 \\
\hline 92 & LnP & LnN & $\begin{array}{r}5.32 \\
\pm 0.012 \\
\end{array}$ & $<0.001$ & $\begin{array}{r}0.9873 \\
\pm 0.0128 \\
\end{array}$ & $<0.001$ & - & - & 98.5 & 0.196 \\
\hline \multirow[t]{4}{*}{89} & $\mathrm{Ca}, \mathrm{g}$ & EBW & - & - & $\begin{array}{r}8.57 \\
\pm 0.105 \\
\end{array}$ & $<0.001$ & - & - & 95.6 & 124 \\
\hline & & & $\begin{array}{r}-8.7 \\
\pm 14.3 \\
\end{array}$ & 0.546 & $\begin{array}{r}8.68 \\
\pm 0.20 \\
\end{array}$ & $<0.001$ & - & - & 95.5 & 124 \\
\hline & & & - & - & $\begin{array}{r}8.17 \\
\pm 0.46 \\
\end{array}$ & $<0.001$ & $\begin{array}{r}0.0043 \\
\pm 0.0048 \\
\end{array}$ & 0.378 & 95.5 & 124 \\
\hline & & & $\begin{array}{r}0.60 \\
\pm 20.4 \\
\end{array}$ & 0.976 & $\begin{array}{r}8.15 \\
\pm 0.84 \\
\end{array}$ & $<0.001$ & $\begin{array}{r}0.0044 \\
\pm 0.0069 \\
\end{array}$ & 0.523 & 95.5 & 124 \\
\hline \multirow[t]{4}{*}{85} & $\mathrm{Ca}$ & $\mathrm{N}, \mathrm{kg}$ & - & - & $\begin{array}{l}328.2 \\
\pm 4.21 \\
\end{array}$ & $<0.001$ & - & - & 95.2 & 127 \\
\hline & & & $\begin{array}{r}-11.0 \\
\pm 15.7 \\
\end{array}$ & 0.485 & $\begin{array}{r}333.2 \\
\pm 8.26 \\
\end{array}$ & $<0.001$ & - & - & 95.1 & 127 \\
\hline & & & - & - & $\begin{array}{r}292.8 \\
\pm 19.5 \\
\end{array}$ & $<0.001$ & $\begin{array}{r}14.5 \\
\pm 7.80 \\
\end{array}$ & 0.067 & 95.3 & 125 \\
\hline & & & $\begin{array}{r}21.5 \\
\pm 22.7 \\
\end{array}$ & 0.345 & $\begin{array}{l}263.6 \\
\pm 36.4 \\
\end{array}$ & $<0.001$ & $\begin{array}{r}22.5 \\
\pm 11.5 \\
\end{array}$ & 0.054 & 95.3 & 125 \\
\hline 89 & LnCa & $\begin{array}{l}\text { Ln } \\
\text { EBW }\end{array}$ & $\begin{array}{r}2.059 \\
\pm 0.054 \\
\end{array}$ & $<0.001$ & $\begin{array}{l}1.0180 \\
\pm 0.014 \\
\end{array}$ & $<0.001$ & - & - & 98.4 & 0.22 \\
\hline 84 & LnCa & LnN & $\begin{array}{r}5.78 \\
\pm 0.015 \\
\end{array}$ & $<0.001$ & $\begin{array}{r}1.0013 \\
\pm 0.0157 \\
\end{array}$ & $<0.001$ & - & - & 98.0 & 0.23 \\
\hline 89 & LnCa & LnP & $\begin{array}{r}0.385 \\
\pm 0.046 \\
\end{array}$ & $<0.001$ & $\begin{array}{r}1.0135 \\
\pm 0.0083 \\
\end{array}$ & $<0.001$ & - & - & 99.4 & 0.13 \\
\hline \multirow[t]{2}{*}{89} & $\mathrm{Ca} / \mathrm{P}^{1)}$ & EBW & $\begin{array}{r}1.555 \\
\pm 0.0005 \\
\end{array}$ & $<0.001$ & $\begin{array}{r}0.00050 \\
\pm 0.00035 \\
\end{array}$ & 0.158 & - & - & 1.2 & 0.22 \\
\hline & & & $\begin{array}{r}1.569 \\
\pm 0.036 \\
\end{array}$ & $<0.001$ & $\begin{array}{r}-0.00026 \\
\pm 0.0015 \\
\end{array}$ & 0.861 & $\begin{array}{r}0.0000064 \\
\pm 0.0000121 \\
\end{array}$ & 0.598 & 0.3 & 0.22 \\
\hline \multirow[t]{4}{*}{104} & EBW & LW & - & - & $\begin{array}{r}0.950 \\
\pm 0.0017 \\
\end{array}$ & $<0.001$ & - & - & 99.9 & 2.24 \\
\hline & & & $\begin{array}{l}-0.418 \\
\pm 0.240\end{array}$ & 0.085 & $\begin{array}{r}0.955 \\
\pm 0032 \\
\end{array}$ & $<0.001$ & - & - & 99.9 & 2.22 \\
\hline & & & - & - & $\begin{array}{r}0.934 \\
\pm 0.0073 \\
\end{array}$ & $<0.001$ & $\begin{array}{r}0.000162 \\
\pm 0.000072 \\
\end{array}$ & 0.027 & 99.9 & 2.20 \\
\hline & & & $\begin{array}{r}-0.056 \\
\pm 0.35 \\
\end{array}$ & 0.875 & $\begin{array}{r}0.936 \\
\pm 0.0139 \\
\end{array}$ & $<0.001$ & $\begin{array}{r}0.000149 \\
\pm 0.000108 \\
\end{array}$ & 0.168 & 99.9 & 2.21 \\
\hline
\end{tabular}

1) No added value using $\mathrm{N}$ (in $\mathrm{kg}$ ) as independent variable 


\section{Annex 5 Residual plots for prediction of body P mass}
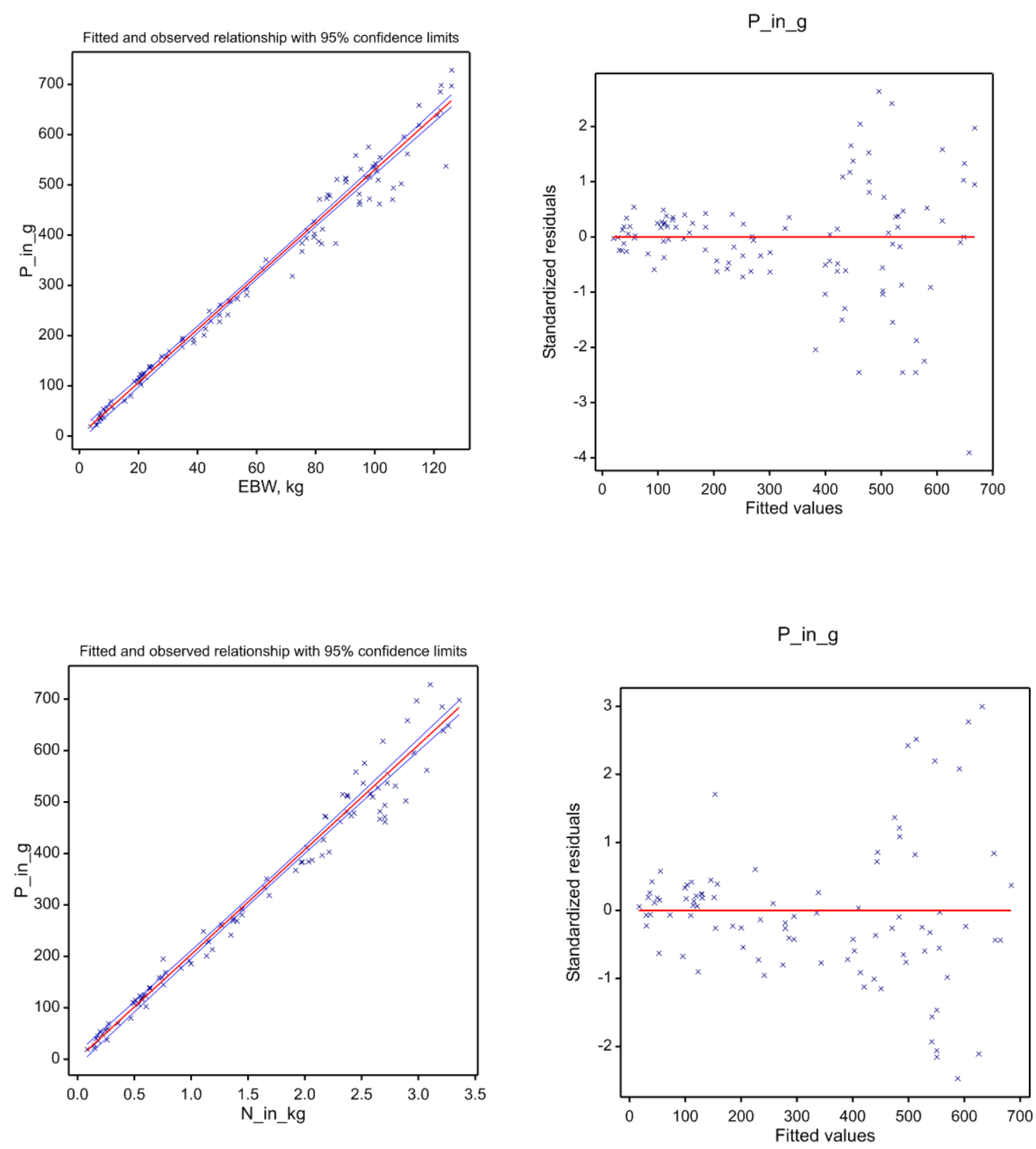

Fitted regression line and confidence interval (left panels) and standardised residuals (right panels) for the relationship between body $\mathrm{P}$ mass with EBW (top panels) and body $\mathrm{N}$ mass (lower panels) as independent variables. 


\section{Annex 6 Residual plots for prediction of LN body P mass}

LNP
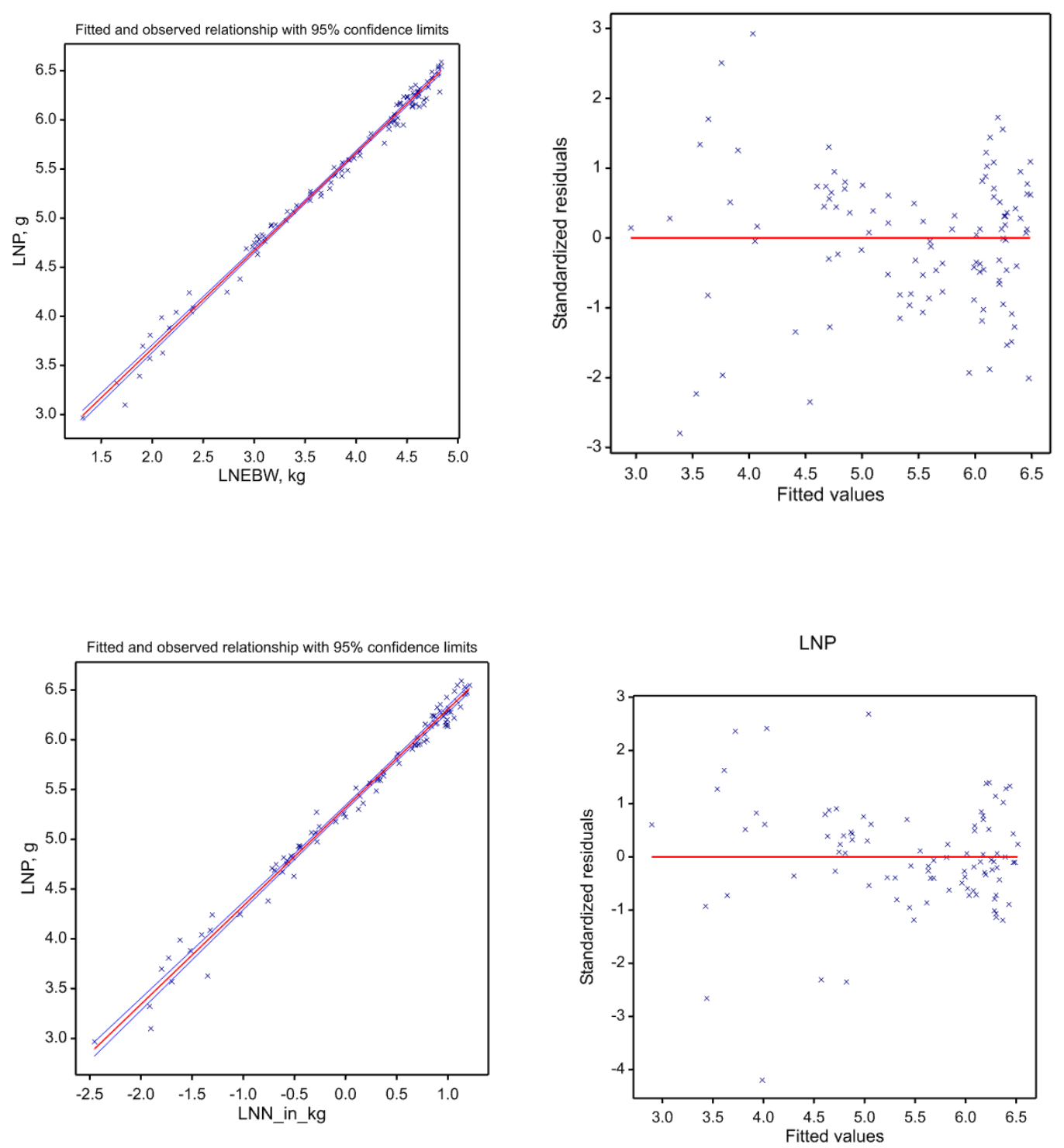

Fitted regression line and confidence interval (left panels) and standardised residuals (right panels) for the relationship between LN body P mass with LN EBW (top panels) and LN body $\mathrm{N}$ mass (lower panels) as independent variable. 


\section{Annex $7 \mathrm{P}$ and $\mathrm{Ca}$ retention in growing pigs}

Phosphorus and calcium retention in growing pigs, expressed per kg live weight gain (LWG)

\begin{tabular}{|c|c|c|c|c|c|c|}
\hline & \multicolumn{2}{|c|}{$\begin{array}{l}\text { Jongbloed et } \\
\text { al. (2003) }\end{array}$} & \multicolumn{2}{|c|}{ Dataset $\geq 1985$} & \multicolumn{2}{|c|}{$\begin{array}{l}\text { Dataset } \geq 1985 \text {, } \\
\text { simplified }\end{array}$} \\
\hline $\mathrm{LW}, \mathrm{kg}$ & $\mathrm{P}$ & $\mathrm{Ca}$ & $\mathrm{P}^{1)}$ & $\left(\mathrm{Ca}^{2)}\right.$ & $\mathrm{P}^{3)}$ & $\left(a^{4)}\right.$ \\
\hline 5 & 5.05 & 7.66 & 4.97 & 7.67 & 5.05 & 7.83 \\
\hline 10 & 5.06 & 7.87 & 4.97 & 7.77 & 5.05 & 7.83 \\
\hline 15 & 5.07 & 8.00 & 4.98 & 7.83 & 5.05 & 7.83 \\
\hline 20 & 5.08 & 8.09 & 4.98 & 7.88 & 5.05 & 7.83 \\
\hline 25 & 5.09 & 8.16 & 4.99 & 7.92 & 5.05 & 7.83 \\
\hline 30 & 5.10 & 8.23 & 4.99 & 7.95 & 5.05 & 7.83 \\
\hline 35 & 5.10 & 8.28 & 5.00 & 7.98 & 5.05 & 7.83 \\
\hline 40 & 5.11 & 8.33 & 5.00 & 8.01 & 5.05 & 7.83 \\
\hline 45 & 5.11 & 8.37 & 5.01 & 8.03 & 5.05 & 8.09 \\
\hline 50 & 5.12 & 8.41 & 5.01 & 8.06 & 5.05 & 8.09 \\
\hline 55 & 5.12 & 8.44 & 5.02 & 8.08 & 5.05 & 8.09 \\
\hline 60 & 5.13 & 8.48 & 5.02 & 8.10 & 5.05 & 8.09 \\
\hline 65 & 5.13 & 8.51 & 5.03 & 8.11 & 5.05 & 8.09 \\
\hline 70 & 5.13 & 8.54 & 5.03 & 8.13 & 5.05 & 8.09 \\
\hline 75 & 5.14 & 8.56 & 5.03 & 8.15 & 5.05 & 8.09 \\
\hline 80 & 5.14 & 8.59 & 5.04 & 8.17 & 5.05 & 8.09 \\
\hline 85 & 5.15 & 8.61 & 5.04 & 8.18 & 5.05 & 8.09 \\
\hline 90 & 5.15 & 8.64 & 5.05 & 8.20 & 5.05 & 8.09 \\
\hline 95 & 5.15 & 8.66 & 5.05 & 8.21 & 5.05 & 8.09 \\
\hline 100 & 5.16 & 8.68 & 5.06 & 8.23 & 5.05 & 8.09 \\
\hline 105 & 5.16 & 8.70 & 5.06 & 8.24 & 5.05 & 8.09 \\
\hline 110 & 5.16 & 8.72 & 5.07 & 8.26 & 5.05 & 8.09 \\
\hline 115 & 5.17 & 8.74 & 5.07 & 8.27 & 5.05 & 8.09 \\
\hline 120 & & & 5.07 & 8.28 & 5.05 & 8.09 \\
\hline 125 & & & 5.08 & 8.30 & 5.05 & 8.09 \\
\hline 130 & & & 5.08 & 8.31 & 5.05 & 8.09 \\
\hline 135 & & & 5.09 & 8.32 & 5.05 & 8.09 \\
\hline \multicolumn{7}{|c|}{$\begin{array}{l}\text { 1) Based on equation } 3 \text { and } 6 \text { in this report. } P(g / k g ~ L W G)=e^{1.67} \times 1.0004 \times E B W W^{0.0004} \times E B W / L W \text { with } \\
E B W=0.9338 \times L W+0.000162 \times L^{2}\end{array}$} \\
\hline \multicolumn{7}{|c|}{$\begin{array}{l}\text { 2) Based on equation } 4 \text { and } 6 \text { in this report. } \mathrm{Ca}(\mathrm{g} / \mathrm{kg} \mathrm{LWG})=\mathrm{e}^{2.059} \times 1.018 \times \mathrm{EBW}^{0.018} \times \mathrm{EBW} / \mathrm{LW} \text { with } \\
\mathrm{EBW}=0.9338 \times \mathrm{LW}+0.000162 \times \mathrm{LW}^{2}\end{array}$} \\
\hline \multicolumn{7}{|c|}{ 3) $P(g / k g ~ L W G)=5.32 \times 0.95$} \\
\hline & & & & & & \\
\hline
\end{tabular}




\section{Annex $8 \mathrm{Ca}$ and $\mathrm{P}$ required in weaned pigs}

Calculated requirements of standardised total tract digestible (STTD) phosphorus (dP) and STTD and total calcium in weaned pigs ( $\mathrm{dCa}$ en $\mathrm{Ca}$, respectively). The results are based on feed intake and growth performance derived from results in experiments conducted at VIC Sterksel, swine research centre of Wageningen UR. Feed intake (FI), live weight (LW), daily gain (LWG) and energy conversion ratio (EWC) are calculated on a daily basis in weekly periods after weaning.

\begin{tabular}{|c|c|c|c|c|c|c|c|c|c|c|c|}
\hline Day & $\begin{array}{l}\mathrm{FL}, \\
\times \mathrm{M} \\
\end{array}$ & $\begin{array}{c}\text { ADG, } \\
\mathrm{g} / \mathrm{d}\end{array}$ & $\begin{array}{c}\text { BW, } \\
\mathrm{kg}\end{array}$ & $\begin{array}{c}\mathrm{FI}, \\
\mathrm{EW} / \mathrm{d}\end{array}$ & $\begin{array}{c}\text { FCR, } \\
\text { EW/kg }\end{array}$ & $\begin{array}{c}\mathrm{dP}^{1)}, \\
\mathrm{g} / \mathrm{d}\end{array}$ & $\begin{array}{c}d^{2)}, \\
g / d\end{array}$ & $\begin{array}{c}\mathrm{dCa}^{1)}, \\
\mathrm{g} / \mathrm{d}\end{array}$ & $\begin{array}{c}\left.\mathrm{dCa}^{2}\right) \\
\mathrm{g} / \mathrm{d}\end{array}$ & $\begin{array}{l}\mathrm{dP}^{1)}, \\
\mathrm{g} / \mathrm{EW}\end{array}$ & $\begin{array}{l}\mathrm{Ca}^{1,3)}, \\
\mathrm{g} / \mathrm{EW}\end{array}$ \\
\hline 1 & 0.91 & 101 & 7.60 & 0.142 & 1.41 & 0.57 & 0.57 & 0.87 & 0.88 & 3.98 & 10.24 \\
\hline 2 & 1.06 & 122 & 7.72 & 0.168 & 1.38 & 0.67 & 0.68 & 1.04 & 1.05 & 4.00 & 10.30 \\
\hline 3 & 1.21 & 142 & 7.86 & 0.194 & 1.36 & 0.78 & 0.79 & 1.20 & 1.21 & 4.00 & 10.32 \\
\hline 4 & 1.35 & 162 & 8.03 & 0.220 & 1.36 & 0.88 & 0.89 & 1.36 & 1.38 & 4.00 & 10.31 \\
\hline 5 & 1.49 & 183 & 8.21 & 0.247 & 1.35 & 0.98 & 1.00 & 1.52 & 1.54 & 3.98 & 10.28 \\
\hline 6 & 1.63 & 202 & 8.41 & 0.274 & 1.36 & 1.09 & 1.10 & 1.68 & 1.70 & 3.96 & 10.23 \\
\hline 7 & 1.76 & 222 & 8.63 & 0.302 & 1.36 & 1.19 & 1.21 & 1.84 & 1.86 & 3.93 & 10.16 \\
\hline 8 & 1.88 & 242 & 8.88 & 0.331 & 1.37 & 1.29 & 1.31 & 2.00 & 2.02 & 3.90 & 10.08 \\
\hline 9 & 2.00 & 261 & 9.14 & 0.360 & 1.38 & 1.39 & 1.41 & 2.16 & 2.18 & 3.86 & 10.00 \\
\hline 10 & 2.12 & 280 & 9.42 & 0.389 & 1.39 & 1.49 & 1.51 & 2.31 & 2.33 & 3.82 & 9.90 \\
\hline 11 & 2.23 & 299 & 9.72 & 0.419 & 1.40 & 1.59 & 1.61 & 2.47 & 2.49 & 3.78 & 9.80 \\
\hline 12 & 2.34 & 318 & 10.03 & 0.450 & 1.42 & 1.68 & 1.71 & 2.62 & 2.64 & 3.74 & 9.70 \\
\hline 13 & 2.44 & 336 & 10.37 & 0.482 & 1.43 & 1.78 & 1.81 & 2.77 & 2.79 & 3.69 & 9.59 \\
\hline 14 & 2.54 & 354 & 10.72 & 0.514 & 1.45 & 1.88 & 1.90 & 2.92 & 2.94 & 3.65 & 9.48 \\
\hline 15 & 2.63 & 373 & 11.10 & 0.546 & 1.47 & 1.97 & 2.00 & 3.07 & 3.09 & 3.60 & 9.37 \\
\hline 16 & 2.72 & 390 & 11.49 & 0.580 & 1.48 & 2.06 & 2.09 & 3.22 & 3.24 & 3.56 & 9.26 \\
\hline 17 & 2.81 & 408 & 11.89 & 0.614 & 1.50 & 2.16 & 2.19 & 3.37 & 3.38 & 3.52 & 9.15 \\
\hline 18 & 2.88 & 426 & 12.32 & 0.648 & 1.52 & 2.25 & 2.28 & 3.51 & 3.53 & 3.47 & 9.04 \\
\hline 19 & 2.96 & 443 & 12.76 & 0.682 & 1.54 & 2.34 & 2.37 & 3.66 & 3.67 & 3.43 & 8.93 \\
\hline 20 & 3.03 & 460 & 13.22 & 0.717 & 1.56 & 2.43 & 2.46 & 3.80 & 3.81 & 3.39 & 8.83 \\
\hline 21 & 3.10 & 477 & 13.70 & 0.753 & 1.58 & 2.52 & 2.56 & 3.94 & 3.95 & 3.35 & 8.73 \\
\hline 22 & 3.16 & 494 & 14.19 & 0.788 & 1.60 & 2.61 & 2.64 & 4.08 & 4.09 & 3.31 & 8.64 \\
\hline 23 & 3.21 & 510 & 14.70 & 0.824 & 1.62 & 2.70 & 2.73 & 4.22 & 4.22 & 3.27 & 8.55 \\
\hline 24 & 3.27 & 526 & 15.23 & 0.860 & 1.63 & 2.78 & 2.82 & 4.36 & 4.36 & 3.24 & 8.46 \\
\hline 25 & 3.31 & 543 & 15.77 & 0.895 & 1.65 & 2.87 & 2.91 & 4.50 & 4.49 & 3.20 & 8.38 \\
\hline 26 & 3.36 & 558 & 16.33 & 0.931 & 1.67 & 2.95 & 2.99 & 4.64 & 4.63 & 3.17 & 8.30 \\
\hline 27 & 3.39 & 574 & 16.91 & 0.966 & 1.68 & 3.04 & 3.08 & 4.77 & 4.76 & 3.14 & 8.23 \\
\hline 28 & 3.43 & 590 & 17.49 & 1.001 & 1.70 & 3.12 & 3.16 & 4.90 & 4.89 & 3.12 & 8.17 \\
\hline 29 & 3.46 & 605 & 18.10 & 1.035 & 1.71 & 3.20 & 3.25 & 5.04 & 5.02 & 3.09 & 8.11 \\
\hline 30 & 3.48 & 620 & 18.72 & 1.069 & 1.72 & 3.29 & 3.33 & 5.17 & 5.14 & 3.07 & 8.05 \\
\hline 31 & 3.50 & 635 & 19.35 & 1.103 & 1.74 & 3.37 & 3.41 & 5.30 & 5.27 & 3.05 & 8.01 \\
\hline 32 & 3.51 & 650 & 20.00 & 1.135 & 1.75 & 3.45 & 3.49 & 5.43 & 5.39 & 3.04 & 7.97 \\
\hline 33 & 3.53 & 664 & 20.67 & 1.167 & 1.76 & 3.52 & 3.57 & 5.55 & 5.52 & 3.02 & 7.93 \\
\hline 34 & 3.53 & 678 & 21.35 & 1.197 & 1.77 & 3.60 & 3.65 & 5.68 & 5.64 & 3.01 & 7.90 \\
\hline 35 & 3.53 & 693 & 22.04 & 1.227 & 1.77 & 3.68 & 3.73 & 5.80 & 5.76 & 3.00 & 7.88 \\
\hline 36 & 3.53 & 706 & 22.75 & 1.256 & 1.78 & 3.76 & 3.80 & 5.93 & 5.87 & 2.99 & 7.86 \\
\hline 37 & 3.53 & 720 & 23.47 & 1.286 & 1.79 & 3.83 & 3.88 & 6.05 & 5.99 & 2.98 & 7.84 \\
\hline 38 & 3.53 & 734 & 24.20 & 1.316 & 1.79 & 3.91 & 3.95 & 6.17 & 6.11 & 2.97 & 7.81 \\
\hline 39 & 3.53 & 747 & 24.95 & 1.346 & 1.80 & 3.98 & 4.03 & 6.29 & 6.22 & 2.96 & 7.78 \\
\hline 40 & 3.53 & 760 & 25.71 & 1.377 & 1.81 & 4.05 & 4.10 & 6.40 & 6.33 & 2.94 & 7.75 \\
\hline 41 & 3.53 & 773 & 26.48 & 1.408 & 1.82 & 4.12 & 4.17 & 6.52 & 6.44 & 2.93 & 7.72 \\
\hline 42 & 3.53 & 786 & 27.26 & 1.439 & 1.83 & 4.19 & 4.24 & 6.64 & 6.55 & 2.91 & 7.68 \\
\hline
\end{tabular}

1) $\mathrm{dP}$ and $\mathrm{dCa}(\mathrm{g} / \mathrm{d}$ and $\mathrm{g} / \mathrm{EW})$ using allometric relationships derived in the report (see also Annex 7 ). $\mathrm{dP}(\mathrm{g} / \mathrm{d})=\left(\mathrm{e}^{1.67} \times 1.0004 \times \mathrm{EBW}^{0.0004} \times \mathrm{EBW} / \mathrm{LW}\right) \times \mathrm{LWG}$ (in $\left.\mathrm{kg} / \mathrm{d}\right) / 0.98+0.007 \times \mathrm{LW}$ $\mathrm{dCa}(\mathrm{g} / \mathrm{d})=\left(\mathrm{e}^{2.059} \times 1.018 \times \mathrm{EBW}^{0.018} \times \mathrm{EBW} / \mathrm{LW}\right) \times \mathrm{LWG}($ in $\mathrm{kg} / \mathrm{d}) / 0.98+0.010 \times \mathrm{LW}$

2) $\mathrm{dP}$ and $\mathrm{dCa}$ in $\mathrm{g} / \mathrm{d}$ calculated using simplified relationships derived in the report (see also Annex 7 ) $\mathrm{dP}(\mathrm{g} / \mathrm{d})=5.32 \times 0.95 \times \mathrm{LWG}($ in $\mathrm{kg} / \mathrm{d}) / 0.98+0.007 \times \mathrm{LW}$ $\mathrm{dCa}(\mathrm{g} / \mathrm{d})=1.55 \times 5.32 \times 0.95 \times \mathrm{LWG}($ in $\mathrm{kg} / \mathrm{d}) / 0.98+0.010 \times \mathrm{LW}$

3) Total $\mathrm{Ca} / \mathrm{EW}$ derived from dCa using $60 \%$ standardised total tract digestibility of dietary $\mathrm{Ca}$. 


\section{Annex $9 \mathrm{Ca}$ and $\mathrm{P}$ in growing finishing pigs}

Requirements of standardised total tract digestible phosphorus (dP), calcium ( $d \mathrm{Ca}$ ) and total calcium in growing finishing pigs, calculated using the TMV model (Technisch Model Varkensvoeding). The results are based on the mean feed intake, body weight (BW), average daily gain (ADG) and feed conversion ratio (FCR) in weekly periods after weaning for intact male pigs (Table I), castrated male pigs (Table II) and female pigs (Table III).

Table I. Calculated requirements of intact male pigs

\begin{tabular}{|c|c|c|c|c|c|c|c|c|c|c|c|c|c|}
\hline Wk & Day & $\begin{array}{c}\mathrm{FI}, \\
\text { EW/d }\end{array}$ & $\begin{array}{c}\mathrm{BW}, \\
\mathrm{kg}\end{array}$ & $\begin{array}{c}\text { ADG, } \\
\mathrm{g} / \mathrm{d}\end{array}$ & $\begin{array}{c}\text { FCR, } \\
\text { EW/ } \\
\mathrm{kg}\end{array}$ & $\begin{array}{c}\mathrm{Ca} / \mathrm{P} \\
\text { in } \\
\text { gain }\end{array}$ & $\begin{array}{c}\mathrm{dP}^{1)}, \\
\mathrm{g} / \mathrm{d}\end{array}$ & $\begin{array}{c}\mathrm{dCa}^{1)} \\
\mathrm{g} / \mathrm{d}\end{array}$ & $\begin{array}{c}\mathrm{dCa} / \\
\mathrm{dP}\end{array}$ & $\begin{array}{l}\mathrm{dP} / \\
\mathrm{EW}\end{array}$ & $\begin{array}{l}\mathrm{dCa} \\
/ \mathrm{EW}\end{array}$ & $\begin{array}{l}\mathrm{Ca} / \\
\mathrm{dP}^{2)} \\
\end{array}$ & $\begin{array}{c}\mathrm{Ca} / \\
\mathrm{EW}^{2)}\end{array}$ \\
\hline 1 & 1 & 1.05 & 24.0 & 606 & 1.73 & 1.59 & 3.31 & 5.22 & 1.58 & 3.15 & 4.97 & 2.66 & 8.38 \\
\hline 2 & 8 & 1.25 & 28.2 & 693 & 1.80 & 1.59 & 3.79 & 6.00 & 1.58 & 3.03 & 4.80 & 2.66 & 8.07 \\
\hline 3 & 15 & 1.5 & 33.1 & 779 & 1.93 & 1.60 & 4.27 & 6.77 & 1.59 & 2.85 & 4.51 & 2.66 & 7.57 \\
\hline 4 & 22 & 1.7 & 38.5 & 845 & 2.01 & 1.60 & 4.65 & 7.39 & 1.59 & 2.74 & 4.35 & 2.66 & 7.27 \\
\hline 5 & 29 & 1.9 & 44.5 & 877 & 2.17 & 1.60 & 4.86 & 7.73 & 1.59 & 2.56 & 4.07 & 2.74 & 6.99 \\
\hline 6 & 36 & 2.05 & 50.6 & 890 & 2.30 & 1.61 & 4.97 & 7.92 & 1.59 & 2.42 & 3.86 & 2.74 & 6.63 \\
\hline 7 & 43 & 2.15 & 56.8 & 892 & 2.41 & 1.61 & 5.02 & 8.01 & 1.60 & 2.34 & 3.73 & 2.73 & 6.38 \\
\hline 8 & 50 & 2.25 & 63.1 & 898 & 2.50 & 1.61 & 5.10 & 8.14 & 1.60 & 2.27 & 3.62 & 2.73 & 6.19 \\
\hline 9 & 57 & 2.35 & 69.4 & 907 & 2.59 & 1.62 & 5.19 & 8.29 & 1.60 & 2.21 & 3.53 & 2.73 & 6.02 \\
\hline 10 & 64 & 2.45 & 75.7 & 918 & 2.67 & 1.62 & 5.29 & 8.46 & 1.60 & 2.16 & 3.45 & 2.73 & 5.89 \\
\hline 11 & 71 & 2.55 & 82.1 & 921 & 2.77 & 1.62 & 5.35 & 8.56 & 1.60 & 2.10 & 3.36 & 2.73 & 5.72 \\
\hline 12 & 78 & 2.6 & 88.6 & 915 & 2.84 & 1.62 & 5.36 & 8.58 & 1.60 & 2.06 & 3.30 & 2.72 & 5.61 \\
\hline 13 & 85 & 2.65 & 95.0 & 902 & 2.94 & 1.63 & 5.34 & 8.55 & 1.60 & 2.02 & 3.22 & 2.72 & 5.48 \\
\hline 14 & 92 & 2.65 & 101.3 & 880 & 3.01 & 1.63 & 5.27 & 8.44 & 1.60 & 1.99 & 3.18 & 2.72 & 5.41 \\
\hline 15 & 99 & 2.65 & 107.5 & 862 & 3.08 & 1.63 & 5.22 & 8.35 & 1.60 & 1.97 & 3.15 & 2.71 & 5.34 \\
\hline 16 & 106 & 2.65 & 113.5 & 845 & 3.14 & 1.63 & 5.18 & 8.28 & 1.60 & 1.95 & 3.12 & 2.71 & 5.29 \\
\hline 17 & 113 & 2.65 & 119.4 & 830 & 3.19 & 1.63 & 5.14 & 8.22 & 1.60 & 1.94 & 3.10 & 2.71 & 5.25 \\
\hline 18 & 120 & 2.65 & 125.2 & 817 & 3.24 & 1.63 & 5.11 & 8.17 & 1.60 & 1.93 & 3.08 & 2.71 & 5.22 \\
\hline
\end{tabular}

Intact male pigs parametrised from 24 to $116 \mathrm{~kg}$ with PDmax $155 \mathrm{~g} / \mathrm{d}$, ratio LD/PD 0.04×BW, energetic efficiency of protein (PD) and lipid (LD) deposition of 0.55 and 0.75 , respectively. According to TMV, EBW is calculated as $\mathrm{LW} \times 0.95$. Total $\mathrm{Ca} / \mathrm{EW}$ derived from $\mathrm{dCa}$ using $58 \%$ standardised total tract digestibility of dietary $\mathrm{Ca}$.

1) $\mathrm{dP}$ and $\mathrm{dCa}(\mathrm{g} / \mathrm{d}$ and $\mathrm{g} / \mathrm{EW}$ ) using allometric relationships derived in the report (see also Annex 7 ). $\mathrm{dP}(\mathrm{g} / \mathrm{d})=\left(\mathrm{e}^{1.67} \times 1.0004 \times \mathrm{EBW}^{0.0004} \times \mathrm{EBW} / \mathrm{LW}\right) \times \mathrm{LWG}($ in $\mathrm{kg} / \mathrm{d}) / 0.98+0.007 \times \mathrm{LW}$ $\mathrm{dCa}(\mathrm{g} / \mathrm{d})=\left(\mathrm{e}^{2.059} \times 1.018 \times \mathrm{EBW}^{0.018} \times \mathrm{EBW} / \mathrm{LW}\right) \times \mathrm{LWG}($ in $\mathrm{kg} / \mathrm{d}) / 0.98+0.010 \times \mathrm{LW}$

2) Total $\mathrm{Ca}$ derived from $\mathrm{dCa}$ using $58 \%$ standardised total tract digestibility of dietary $\mathrm{Ca}$. 
Table II. Calculated requirements of castrated male pigs.

\begin{tabular}{|c|c|c|c|c|c|c|c|c|c|c|c|c|c|}
\hline Wk & Day & $\begin{array}{c}\mathrm{FI}, \\
\mathrm{EW} / \mathrm{d}\end{array}$ & $\begin{array}{l}\text { BW, } \\
\text { kg }\end{array}$ & $\begin{array}{c}\text { ADG, } \\
g / d\end{array}$ & $\begin{array}{c}\text { FCR, } \\
\text { EW/ } \\
\mathrm{kg}\end{array}$ & $\begin{array}{l}\mathrm{Ca} / \mathrm{P} \\
\text { in } \\
\text { gain }\end{array}$ & $\begin{array}{c}\mathrm{dP}^{1)}, \\
\mathrm{g} / \mathrm{d}\end{array}$ & $\begin{array}{c}\mathrm{dCa}^{1)}, \\
\mathrm{g} / \mathrm{d}\end{array}$ & $\begin{array}{c}\mathrm{dCa} / \\
\mathrm{dP}\end{array}$ & $\begin{array}{l}\mathrm{dP} / \\
\mathrm{EW}\end{array}$ & $\begin{array}{l}\mathrm{dCa} / \\
\mathrm{EW}\end{array}$ & $\begin{array}{c}\mathrm{Ca} / \mathrm{d} \\
\left.\mathrm{P}^{2}\right)\end{array}$ & $\begin{array}{c}\mathrm{Ca} / \\
\left.\mathrm{EW}^{2}\right)\end{array}$ \\
\hline 1 & 1 & 1.10 & 24.0 & 718 & 1.53 & 1.59 & 3.89 & 6.14 & 1.58 & 3.53 & 5.58 & 2.66 & 9.41 \\
\hline 2 & 8 & 1.35 & 29.0 & 764 & 1.77 & 1.59 & 4.16 & 6.59 & 1.58 & 3.08 & 4.88 & 2.66 & 8.21 \\
\hline 3 & 15 & 1.60 & 34.4 & 806 & 1.99 & 1.60 & 4.42 & 7.01 & 1.59 & 2.76 & 4.38 & 2.66 & 7.34 \\
\hline 4 & 22 & 1.85 & 40.0 & 846 & 2.19 & 1.60 & 4.67 & 7.42 & 1.59 & 2.52 & 4.01 & 2.66 & 6.71 \\
\hline 5 & 29 & 2.10 & 45.9 & 875 & 2.40 & 1.60 & 4.86 & 7.74 & 1.59 & 2.31 & 3.68 & 2.74 & 6.33 \\
\hline 6 & 36 & 2.30 & 52.1 & 893 & 2.58 & 1.61 & 4.99 & 7.96 & 1.59 & 2.17 & 3.46 & 2.74 & 5.93 \\
\hline 7 & 43 & 2.40 & 58.3 & 897 & 2.67 & 1.61 & 5.06 & 8.07 & 1.60 & 2.11 & 3.36 & 2.73 & 5.76 \\
\hline 8 & 50 & 2.50 & 64.6 & 903 & 2.77 & 1.61 & 5.13 & 8.20 & 1.60 & 2.05 & 3.28 & 2.73 & 5.61 \\
\hline 9 & 57 & 2.60 & 70.9 & 902 & 2.88 & 1.62 & 5.17 & 8.27 & 1.60 & 1.99 & 3.18 & 2.73 & 5.43 \\
\hline 10 & 64 & 2.65 & 77.2 & 892 & 2.97 & 1.62 & 5.17 & 8.26 & 1.60 & 1.95 & 3.12 & 2.73 & 5.31 \\
\hline 11 & 71 & 2.70 & 83.5 & 878 & 3.07 & 1.62 & 5.14 & 8.21 & 1.60 & 1.90 & 3.04 & 2.72 & 5.18 \\
\hline 12 & 78 & 2.70 & 89.6 & 858 & 3.15 & 1.62 & 5.08 & 8.11 & 1.60 & 1.88 & 3.01 & 2.72 & 5.11 \\
\hline 13 & 85 & 2.70 & 95.6 & 841 & 3.21 & 1.63 & 5.03 & 8.04 & 1.60 & 1.86 & 2.98 & 2.72 & 5.06 \\
\hline 14 & 92 & 2.70 & 101.5 & 826 & 3.27 & 1.63 & 4.99 & 7.98 & 1.60 & 1.85 & 2.96 & 2.72 & 5.02 \\
\hline 15 & 99 & 2.70 & 107.3 & 814 & 3.32 & 1.63 & 4.97 & 7.94 & 1.60 & 1.84 & 2.94 & 2.71 & 4.99 \\
\hline 16 & 106 & 2.70 & 113.0 & 803 & 3.36 & 1.63 & 4.95 & 7.91 & 1.60 & 1.83 & 2.93 & 2.71 & 4.97 \\
\hline 17 & 113 & 2.70 & 118.6 & 793 & 3.41 & 1.63 & 4.94 & 7.89 & 1.60 & 1.83 & 2.92 & 2.71 & 4.95 \\
\hline 18 & 120 & 270 & 1242 & 784 & 3,44 & 163 & 4.94 & 788 & 160 & 183 & 292 & 271 & 4.94 \\
\hline
\end{tabular}

Castrated male pigs parametrised from 23.5 to $116 \mathrm{~kg}$ with PDmax $135 \mathrm{~g} / \mathrm{d}$, marginal ratio LD/PD -1.5 $+0.085 \times \mathrm{BW}$, energetic efficiency of protein (PD) and lipid (LD) deposition of 0.55 and 0.75 ,

respectively. According to TMV, EBW is calculated as $\mathrm{LW} \times 0.95$. Total $\mathrm{Ca} / \mathrm{EW}$ derived from $\mathrm{dCa}$ using $58 \%$ standardised total tract digestibility of dietary $\mathrm{Ca}$.

1) $\mathrm{dP}$ and $\mathrm{dCa}(\mathrm{g} / \mathrm{d}$ and $\mathrm{g} / \mathrm{EW}$ ) using allometric relationships derived in the report (see also Annex 7 ).

$\mathrm{dP}(\mathrm{g} / \mathrm{d})=\left(\mathrm{e}^{1.67} \times 1.0004 \times \mathrm{EBW}^{0.0004} \times \mathrm{EBW} / \mathrm{LW}\right) \times \mathrm{LWG}($ in $\mathrm{kg} / \mathrm{d}) / 0.98+0.007 \times \mathrm{LW}$

$\mathrm{dCa}(\mathrm{g} / \mathrm{d})=\left(\mathrm{e}^{2.059} \times 1.018 \times \mathrm{EBW}^{0.018} \times \mathrm{EBW} / \mathrm{LW}\right) \times \mathrm{LWG}($ in $\mathrm{kg} / \mathrm{d}) / 0.98+0.010 \times \mathrm{LW}$

2) Total Ca derived from dCa using $58 \%$ standardised total tract digestibility of dietary $\mathrm{Ca}$.

Table III. Calculated requirements of female pigs.

\begin{tabular}{|c|c|c|c|c|c|c|c|c|c|c|c|c|c|}
\hline Wk & Day & $\begin{array}{c}\begin{array}{c}\mathrm{Fl}, \\
\mathrm{EW} / \mathrm{d}\end{array} \\
\end{array}$ & $\begin{array}{c}\text { BW, } \\
\mathrm{kg}\end{array}$ & $\begin{array}{l}\text { ADG, } \\
\text { g/d }\end{array}$ & $\begin{array}{c}\mathrm{FCR}, \\
\mathrm{EW} / \\
\mathrm{kg}\end{array}$ & $\begin{array}{l}\mathrm{Ca} / \mathrm{P} \\
\text { in } \\
\text { gain }\end{array}$ & $\begin{array}{l}d P^{1)}, \\
g / d\end{array}$ & $\begin{array}{c}\mathrm{dCa}^{1)}, \\
\mathrm{g} / \mathrm{d}\end{array}$ & $\begin{array}{l}\mathrm{dCa} \\
/ \mathrm{dP}\end{array}$ & $\begin{array}{l}\mathrm{dP} / \\
\mathrm{EW}\end{array}$ & $\begin{array}{l}\mathrm{dCa} \\
/ \mathrm{EW}\end{array}$ & $\begin{array}{c}\mathrm{Ca} / \\
\left.\mathrm{dP}^{2}\right)\end{array}$ & $\begin{array}{c}\mathrm{Ca} / \\
\mathrm{EW}^{2}\end{array}$ \\
\hline 1 & 1 & 1.10 & 24.0 & 623 & 1.76 & 1.59 & 3.40 & 5.36 & 1.58 & 3.09 & 4.87 & 2.66 & 8.22 \\
\hline 2 & 8 & 1.30 & 28.4 & 703 & 1.85 & 1.59 & 3.84 & 6.08 & 1.58 & 2.95 & 4.67 & 2.66 & 7.86 \\
\hline 3 & 15 & 1.55 & 33.3 & 795 & 1.95 & 1.60 & 4.35 & 6.91 & 1.59 & 2.81 & 4.46 & 2.66 & 7.47 \\
\hline 4 & 22 & 1.80 & 38.8 & 868 & 2.07 & 1.60 & 4.77 & 7.58 & 1.59 & 2.65 & 4.21 & 2.66 & 7.05 \\
\hline 5 & 29 & 2.00 & 44.9 & 888 & 2.25 & 1.60 & 4.92 & 7.83 & 1.59 & 2.46 & 3.91 & 2.74 & 6.73 \\
\hline 6 & 36 & 2.15 & 51.1 & 897 & 2.40 & 1.61 & 5.01 & 7.98 & 1.59 & 2.33 & 3.71 & 2.74 & 6.37 \\
\hline 7 & 43 & 2.25 & 57.4 & 900 & 2.50 & 1.61 & 5.07 & 8.09 & 1.60 & 2.25 & 3.60 & 2.73 & 6.16 \\
\hline 8 & 50 & 2.35 & 63.7 & 905 & 2.60 & 1.61 & 5.14 & 8.21 & 1.60 & 2.19 & 3.49 & 2.73 & 5.97 \\
\hline 9 & 57 & 2.45 & 70.1 & 906 & 2.70 & 1.62 & 5.19 & 8.29 & 1.60 & 2.12 & 3.38 & 2.73 & 5.78 \\
\hline 10 & 64 & 2.50 & 76.4 & 901 & 2.78 & 1.62 & 5.21 & 8.32 & 1.60 & 2.08 & 3.33 & 2.73 & 5.67 \\
\hline 11 & 71 & 2.55 & 82.7 & 897 & 2.84 & 1.62 & 5.23 & 8.36 & 1.60 & 2.05 & 3.28 & 2.72 & 5.58 \\
\hline 12 & 78 & 2.60 & 89.0 & 893 & 2.91 & 1.62 & 5.25 & 8.40 & 1.60 & 2.02 & 3.23 & 2.72 & 5.50 \\
\hline 13 & 85 & 2.65 & 95.2 & 883 & 3.00 & 1.63 & 5.24 & 8.39 & 1.60 & 1.98 & 3.17 & 2.72 & 5.38 \\
\hline 14 & 92 & 2.65 & 101.4 & 863 & 3.07 & 1.63 & 5.19 & 8.30 & 1.60 & 1.96 & 3.13 & 2.72 & 5.32 \\
\hline 15 & 99 & 2.65 & 107.5 & 847 & 3.13 & 1.63 & 5.14 & 8.22 & 1.60 & 1.94 & 3.10 & 2.71 & 5.26 \\
\hline 16 & 106 & 2.65 & 113.4 & 832 & 3.19 & 1.63 & 5.11 & 8.16 & 1.60 & 1.93 & 3.08 & 2.71 & 5.22 \\
\hline 17 & 113 & 2.65 & 119.2 & 818 & 3.24 & 1.63 & 5.08 & 8.11 & 1.60 & 1.92 & 3.06 & 2.71 & 5.19 \\
\hline 18 & 120 & 2.65 & 124.9 & 806 & 3.29 & 1.63 & 5.06 & 8.08 & 1.60 & 1.91 & 3.05 & 2.71 & 5.16 \\
\hline
\end{tabular}

Female pigs parametrised from 23.5 to $116 \mathrm{~kg}$ with PDmax $145 \mathrm{~g} / \mathrm{d}$, marginal ratio LD/PD 0.045×BW, energetic efficiency of protein (PD) and lipid (LD) deposition of 0.55 and 0.75 , respectively. According to TMV, EBW is calculated as $\mathrm{LW} \times 0.95$. Total $\mathrm{Ca} / \mathrm{EW}$ derived from dCa using $58 \%$ standardised total tract digestibility of dietary $\mathrm{Ca}$.

1) $d P$ and $d C a(g / d$ and $g / E W)$ using allometric relationships derived in the report (see also Annex 7 ).

$\mathrm{dP}(\mathrm{g} / \mathrm{d})=\left(\mathrm{e}^{1.67} \times 1.0004 \times \mathrm{EBW}^{0.0004} \times \mathrm{EBW} / \mathrm{LW}\right) \times \mathrm{LWG}$ (in $\left.\mathrm{kg} / \mathrm{d}\right) / 0.98+0.007 \times \mathrm{LW}$

$\mathrm{dCa}(\mathrm{g} / \mathrm{d})=\left(\mathrm{e}^{2.059} \times 1.018 \times \mathrm{EBW}^{0.018} \times \mathrm{EBW} / \mathrm{LW}\right) \times \mathrm{LWG}$ (in $\left.\mathrm{kg} / \mathrm{d}\right) / 0.98+0.010 \times \mathrm{LW}$

2) Total Ca derived from dCa using $58 \%$ standardised total tract digestibility of dietary Ca. 


\section{Annex 10 Composition of new born piglets}

References and characteristics of studies used to calculate calcium and phosphorus content in newborn piglets

\begin{tabular}{lccccc}
\hline Reference & Year & Pigs, $\mathrm{n}$ & $\mathrm{BW}, \mathrm{kg}$ & $\begin{array}{c}\mathrm{Ca}, \mathrm{g} / \mathrm{kg} \\
\mathrm{BW}\end{array}$ & $\mathrm{P}, \mathrm{g} / \mathrm{kg} \mathrm{BW}$ \\
\hline Becker et al. & 1979 & 6 & 1.33 & 14.7 & 6.7 \\
Berge and Indrebo & 1954 & 4 & 1.24 & 10.0 & 6.0 \\
Berge and Indrebo & 1954 & 2 & 1.00 & 12.0 & 6.0 \\
Bikker et al. & 2017 & 14 & 1.14 & 8.4 & 5.6 \\
Bikker et al. & 2017 & 11 & 0.97 & 8.9 & 5.6 \\
Freese & 1958 & 1 & 1.24 & 10.4 & 6.2 \\
Jongbloed et al. & 2002 & 6 & 1.27 & 9.8 & 6.0 \\
Lenkeit & 1957 & 6 & 1.16 & 11.3 & 6.6 \\
Mahan and & & & & & \\
Shields & 1998 & 9 & 1.55 & 9.8 & 5.7 \\
Mahan et al. & 2009 & 6 & 1.39 & 7.5 & 4.6 \\
Manners and & & & & & \\
McCrea & 1963 & 3 & 1.52 & 11.0 & 6.1 \\
Mudd et al. & 1969 & 6 & 1.21 & 11.8 & 5.9 \\
Mudd et al. & 1969 & 8 & 1.51 & 10.7 & 6.0 \\
Peters et al. & 2010 & 69 & 1.54 & 7.6 & 4.5 \\
Pomeroy & 1960 & - & 1.13 & 10.7 & 6.3 \\
Thomsen & 1952 & 6 & 1.30 & 12.3 & 6.9 \\
Urbanyi & 1952 & 2 & 1.30 & 12.3 & 6.9 \\
Weniger and Funk & 1953 & 3 & 1.00 & 10.8 & 6.3 \\
Widdowson & 1950 & 16 & 1.46 & 10.0 & 5.8 \\
Mean & & & & & \\
Standard deviation & & & 0.18 & 10.52 & 5.98 \\
Pand & & & & & 0.64 \\
\hline
\end{tabular}




\section{Annex 11 Protein in placenta and uterine fluids}

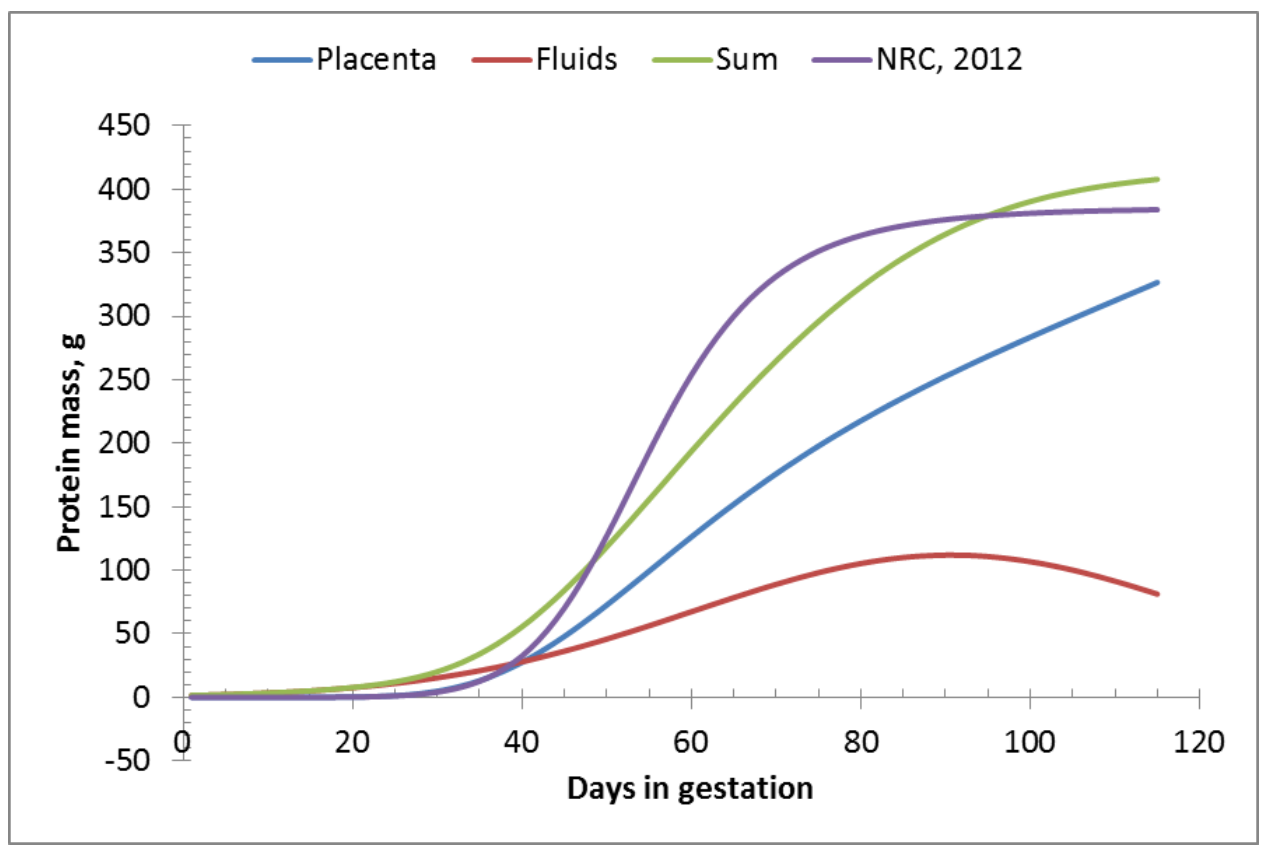

Protein mass in placenta, uterine fluids and their sum based on equations derived by Noblet et al. (1985), as used in the present study, and by NRC (2012). The equation of Noblet et al. (1985) includes an effect of litter size and is based on a litter size of 12 piglets in the figure. The equation of NRC (2012) is derived from results with a litter size of 12 piglets, but corrected by the ratio between actual and predicted litter birth weight. 
Annex 12 Protein in the mammary gland

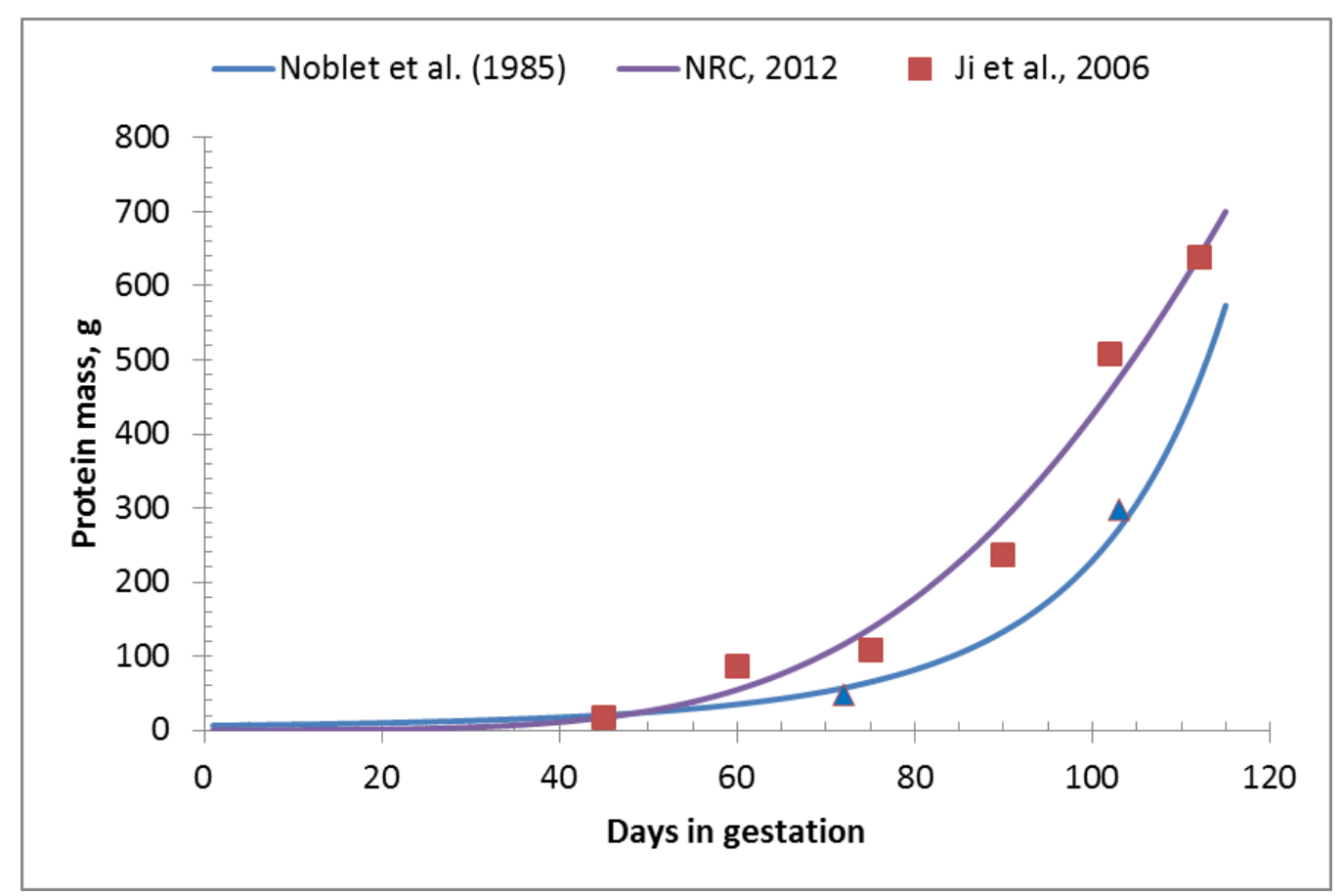

Protein mass in the mammary gland in studies of Noblet et al. (1985) and Ji et al. (2006) and simulated by equations from Noblet et al. (1985) and NRC (2012). 


\section{Annex 13 Description of sow characteristics}

Description of sow characteristics assumed representative for a contemporary sow herd, derived from CVB (2012) and used for the calculation of $P$ and Ca requirements.

\begin{tabular}{|c|c|c|c|c|c|}
\hline Parity & 1 & 2 & 3 & 4 & 5 \\
\hline \multicolumn{6}{|l|}{ Mating } \\
\hline Body weight, $\mathrm{kg}$ & 140 & 165 & 185 & 205 & 220 \\
\hline Back fat, $\mathrm{mm}$ & 13 & 12 & 13 & 13 & 13 \\
\hline Protein mass, $\mathrm{kg}$ & 21.8 & 26.4 & 29.5 & 32.9 & 35.5 \\
\hline Lipid mass, kg & 27.6 & 28.2 & 32.2 & 34.2 & 35.8 \\
\hline \multicolumn{6}{|l|}{ Gestation } \\
\hline Maternal gain, $\mathrm{kg}$ & 55 & 50 & 45 & 40 & 35 \\
\hline - $\quad$ Of which real growth, $\mathrm{kg}$ & 55 & 20 & 15 & 15 & 10 \\
\hline - Of which restoration of mobilisation, $\mathrm{kg}$ & 0 & 30 & 30 & 25 & 25 \\
\hline Maternal protein deposition, kg & 8.2 & 7.0 & 6.5 & 5.6 & 4.7 \\
\hline Maternal lipid deposition, $\mathrm{kg}$ & 13.7 & 14.7 & 12.2 & 11.7 & 11.2 \\
\hline \multicolumn{6}{|l|}{ Farrowing } \\
\hline Maternal body weight, kg & 195 & 215 & 230 & 245 & 255 \\
\hline Back fat, mm & 17 & 17 & 17 & 17 & 17 \\
\hline Protein mass, kg & 30.0 & 33.4 & 36.0 & 38.5 & 40.2 \\
\hline Lipid mass, kg & 40.8 & 42.9 & 44.4 & 45.9 & 47.0 \\
\hline \multicolumn{6}{|l|}{ Lactation and interval } \\
\hline BW loss, kg ${ }^{1)}$ & 30 & 30 & 25 & 25 & 20 \\
\hline - $\quad$ body protein mobilisation, $\mathrm{kg}$ & 3.6 & 3.9 & 3.0 & 3.0 & 2.2 \\
\hline - $\quad$ body lipid mobilisation, kg & 12.6 & 10.7 & 10.2 & 10.2 & 9.7 \\
\hline Litter size & 15 & 16 & 16 & 16 & 16 \\
\hline Birth weight, $\mathrm{kg}$ & 1.25 & 1.4 & 1.4 & 1.4 & 1.4 \\
\hline
\end{tabular}

1) Including a weight loss of $7.5 \mathrm{~kg}$ and $0.75 \mathrm{~mm}$ backfat after weaning, including involution of the mammary gland. 


\section{Annex 14 Calculated $P$ and Ca requirements of gestating sows}

\section{Parity 1}

Factorial estimation of standardised digestible phosphorus (STTD-P) and calcium (STTD-P) requirements in gestating sows to replace faecal and urinary endogenous losses, and for retention in maternal and foetal tissues, expressed per day and per EW.

STTD-P requirements STTD-Ca requirements

BW, Feed, endogenous, maternal, foetal, total, total, endogenous, maternal, foetal, total, total,

Total $\mathrm{Ca}^{1)}$

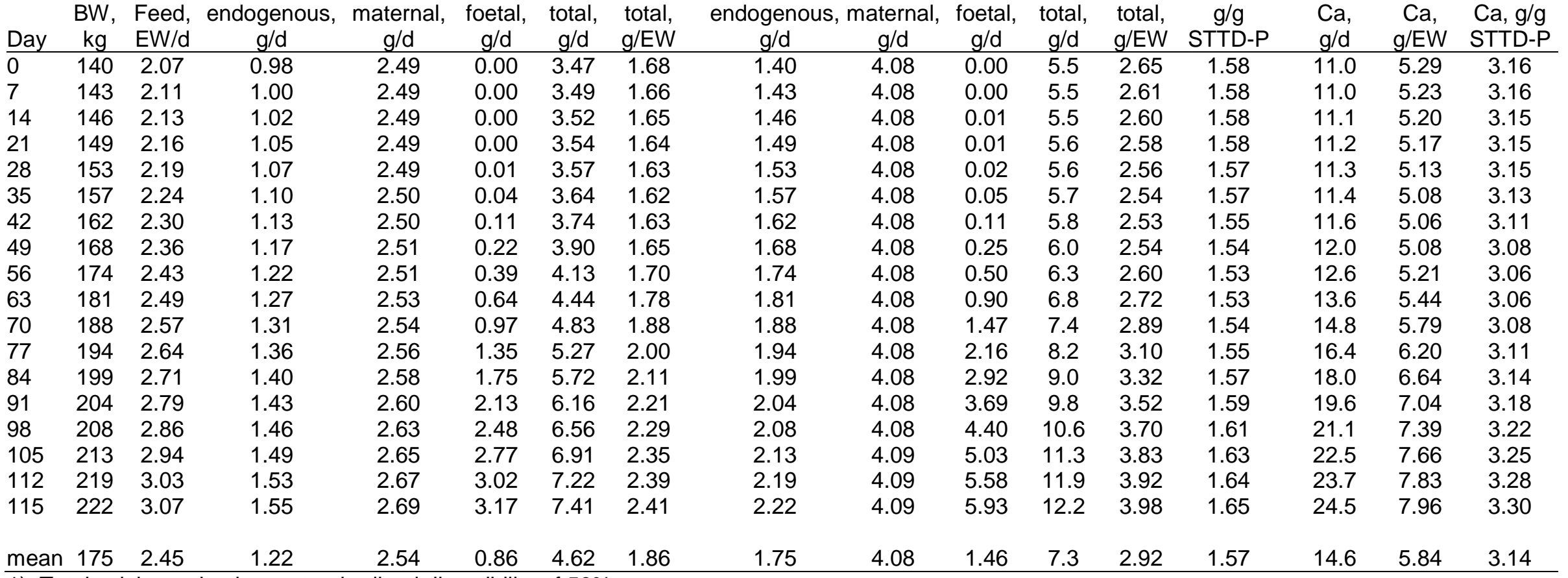

1) Total calcium adopting a standardised digestibility of $50 \%$. 
Parity 2

Factorial estimation of standardised digestible phosphorus (STTD-P) and calcium (STTD-P) requirements in gestating sows to replace faecal and urinary endogenous losses, and for retention in maternal and foetal tissues, expressed per day and per EW.

STTD-P requirements STTD-Ca requirements

BW, Feed, endogenous, maternal, foetal, total, total, endogenous, maternal, foetal, total, total, $\mathrm{g} / \mathrm{g}$ TTD-P Total $\mathrm{Ca}^{1)}$

\begin{tabular}{|c|c|c|c|c|c|c|c|c|c|c|c|c|c|c|c|c|}
\hline Day & $\begin{array}{c}\text { BW, } \\
\mathrm{kg}\end{array}$ & $\begin{array}{l}\text { Feed, } \\
\text { EW/d }\end{array}$ & $\begin{array}{c}\text { endogenous, } \\
\mathrm{g} / \mathrm{d}\end{array}$ & $\begin{array}{c}\text { naternal, } \\
\mathrm{g} / \mathrm{d}\end{array}$ & $\begin{array}{c}\text { toetal, } \\
\mathrm{g} / \mathrm{d}\end{array}$ & $\begin{array}{c}\text { total, } \\
\mathrm{g} / \mathrm{d}\end{array}$ & $\begin{array}{l}\text { total, } \\
\mathrm{g} / \mathrm{EW} \\
\end{array}$ & $\begin{array}{c}\text { endogenous, } \\
\mathrm{g} / \mathrm{d}\end{array}$ & $\begin{array}{c}\text {, maternal, } \\
\text { g/d }\end{array}$ & $\begin{array}{c}\text { toetal, } \\
\mathrm{g} / \mathrm{d}\end{array}$ & $\begin{array}{l}\text { total, } \\
\text { g/d }\end{array}$ & $\begin{array}{l}\text { total, } \\
\mathrm{g} / \mathrm{EW}\end{array}$ & $\begin{array}{c}\text { g/g } \\
\text { STTD-P }\end{array}$ & $\begin{array}{l}\mathrm{Ca}, \\
\mathrm{g} / \mathrm{d}\end{array}$ & $\begin{array}{l}\text { Ca, } \\
\text { g/EW }\end{array}$ & $\begin{array}{l}\mathrm{Ca}, \mathrm{g} / \mathrm{g} \\
\text { STTD-P } \\
\end{array}$ \\
\hline$\overline{0}$ & 165 & 2.27 & 1.16 & 1.17 & 0.00 & 2.33 & 1.02 & 1.65 & 1.64 & 0.00 & 3.29 & 1.45 & 1.41 & 6.59 & 2.90 & 2.83 \\
\hline 7 & 168 & 2.31 & 1.17 & 1.17 & 0.00 & 2.35 & 1.02 & 1.68 & 1.64 & 0.00 & 3.32 & 1.44 & 1.41 & 6.64 & 2.88 & 2.83 \\
\hline 14 & 171 & 2.33 & 1.19 & 1.17 & 0.00 & 2.37 & 1.02 & 1.71 & 1.64 & 0.01 & 3.35 & 1.44 & 1.42 & 6.70 & 2.88 & 2.83 \\
\hline 21 & 173 & 2.35 & 1.21 & 1.17 & 0.00 & 2.39 & 1.02 & 1.73 & 1.64 & 0.01 & 3.39 & 1.44 & 1.42 & 6.77 & 2.88 & 2.83 \\
\hline 28 & 177 & 2.39 & 1.24 & 1.17 & 0.01 & 2.43 & 1.02 & 1.77 & 1.64 & 0.02 & 3.43 & 1.44 & 1.41 & 6.86 & 2.88 & 2.83 \\
\hline 35 & 181 & 2.43 & 1.26 & 1.18 & 0.05 & 2.49 & 1.03 & 1.81 & 1.64 & 0.05 & 3.50 & 1.44 & 1.40 & 7.00 & 2.88 & 2.81 \\
\hline 42 & 186 & 2.49 & 1.30 & 1.18 & 0.13 & 2.61 & 1.05 & 1.86 & 1.64 & 0.13 & 3.63 & 1.46 & 1.39 & 7.26 & 2.92 & 2.78 \\
\hline 49 & 191 & 2.55 & 1.34 & 1.19 & 0.26 & 2.79 & 1.09 & 1.91 & 1.64 & 0.29 & 3.84 & 1.51 & 1.38 & 7.69 & 3.01 & 2.76 \\
\hline 56 & 198 & 2.62 & 1.39 & 1.20 & 0.47 & 3.05 & 1.16 & 1.98 & 1.64 & 0.59 & 4.21 & 1.61 & 1.38 & 8.41 & 3.21 & 2.76 \\
\hline 63 & 205 & 2.69 & 1.43 & 1.21 & 0.77 & 3.41 & 1.27 & 2.05 & 1.64 & 1.07 & 4.76 & 1.77 & 1.40 & 9.52 & 3.54 & 2.79 \\
\hline 70 & 212 & 2.77 & 1.48 & 1.22 & 1.16 & 3.87 & 1.40 & 2.12 & 1.64 & 1.75 & 5.51 & 1.99 & 1.43 & 11.02 & 3.98 & 2.85 \\
\hline 77 & 218 & 2.85 & 1.53 & 1.24 & 1.61 & 4.38 & 1.54 & 2.18 & 1.64 & 2.58 & 6.41 & 2.25 & 1.46 & 12.82 & 4.50 & 2.92 \\
\hline 84 & 224 & 2.93 & 1.57 & 1.26 & 2.09 & 4.92 & 1.68 & 2.24 & 1.64 & 3.49 & 7.38 & 2.52 & 1.50 & 14.75 & 5.04 & 3.00 \\
\hline 91 & 229 & 3.01 & 1.60 & 1.28 & 2.55 & 5.43 & 1.81 & 2.29 & 1.65 & 4.40 & 8.34 & 2.77 & 1.53 & 16.67 & 5.54 & 3.07 \\
\hline 98 & 233 & 3.09 & 1.63 & 1.31 & 2.96 & 5.90 & 1.91 & 2.33 & 1.65 & 5.26 & 9.24 & 2.99 & 1.57 & 18.47 & 5.98 & 3.13 \\
\hline 105 & 238 & 3.17 & 1.66 & 1.33 & 3.31 & 6.31 & 1.99 & 2.38 & 1.65 & 6.02 & 10.04 & 3.16 & 1.59 & 20.08 & 6.33 & 3.18 \\
\hline 112 & 243 & 3.27 & 1.70 & 1.36 & 3.61 & 6.66 & 2.04 & 2.43 & 1.65 & 6.67 & 10.76 & 3.29 & 1.61 & 21.51 & 6.58 & 3.23 \\
\hline 115 & 246 & 3.32 & 1.72 & 1.37 & 3.78 & 6.88 & 2.07 & 2.46 & 1.65 & 7.08 & 11.20 & 3.37 & 1.63 & 22.40 & 6.74 & 3.26 \\
\hline mear & 199 & 2.66 & 1.39 & 1.22 & 1.03 & 3.64 & 1.33 & 1.99 & 1.64 & 1.74 & 5.37 & 1.95 & 1.45 & 10.74 & 3.90 & 2.90 \\
\hline
\end{tabular}

1) Total calcium adopting a standardised digestibility of $50 \%$. 
Parity 3

Factorial estimation of standardised digestible phosphorus (STTD-P) and calcium (STTD-P) requirements in gestating sows to replace faecal and urinary endogenous losses, and for retention in maternal and foetal tissues, expressed per day and per EW.

STTD-P requirements

STTD-Ca requirements

BW, Feed, endogenous, maternal, foetal, total, total, endogenous, maternal, foetal, total, total,

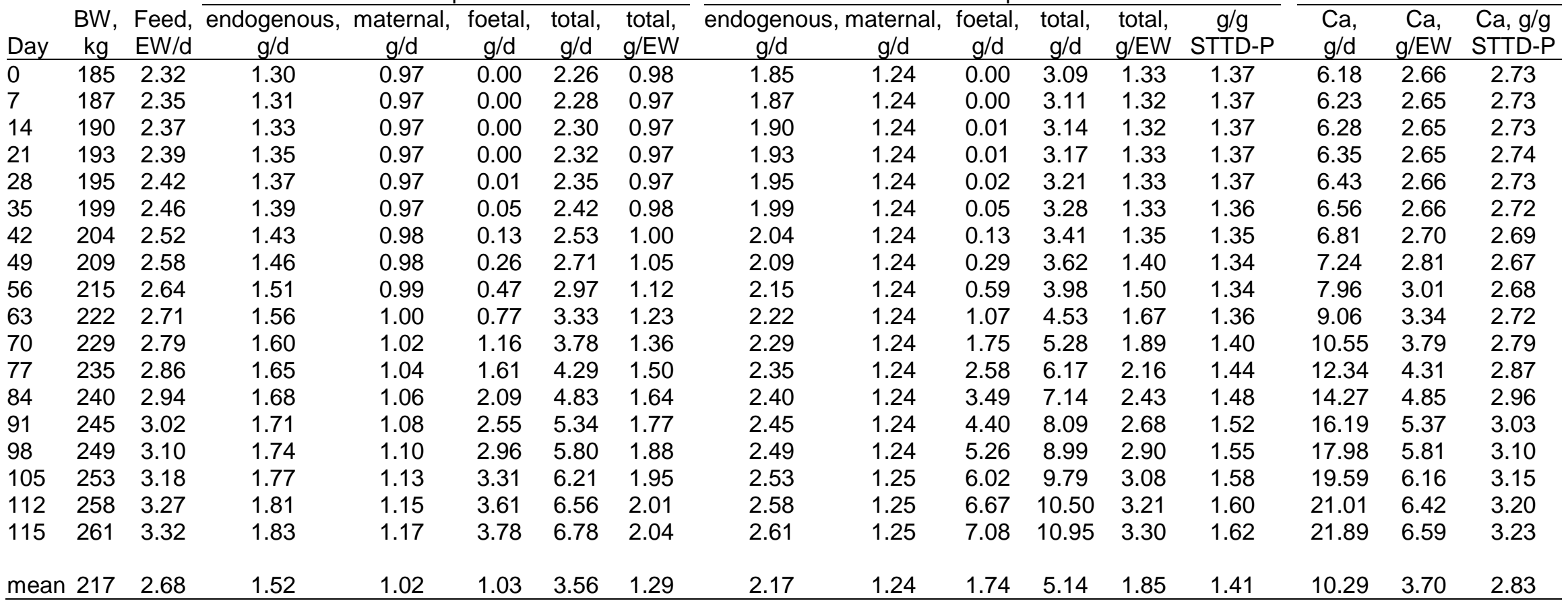

1) Total calcium adopting a standardised digestibility of $50 \%$. 
Parity 4

Factorial estimation of standardised digestible phosphorus (STTD-P) and calcium (STTD-P) requirements in gestating sows to replace faecal and urinary endogenous losses, and for retention in maternal and foetal tissues, expressed per day and per EW.

\begin{tabular}{|c|c|c|c|c|c|c|c|c|c|c|c|c|c|c|c|c|}
\hline \multirow[b]{2}{*}{ Day } & \multirow[b]{2}{*}{$\begin{array}{c}\mathrm{BW}, \\
\mathrm{kg}\end{array}$} & \multirow[b]{2}{*}{$\begin{array}{l}\text { Feed, } \\
\text { EW/d }\end{array}$} & \multicolumn{5}{|c|}{ STTD-P requirements } & \multicolumn{6}{|c|}{ STTD-Ca requirements } & \multicolumn{3}{|c|}{ Total $\mathrm{Ca}^{1)}$} \\
\hline & & & $\begin{array}{c}\text { endogenous, } \\
\mathrm{g} / \mathrm{d}\end{array}$ & $\begin{array}{l}\text { maternal, } \\
\text { g/d }\end{array}$ & $\begin{array}{l}\text { foetal, } \\
\mathrm{g} / \mathrm{d}\end{array}$ & $\begin{array}{l}\text { total, } \\
\mathrm{g} / \mathrm{d}\end{array}$ & $\begin{array}{l}\text { total, } \\
\text { g/EW }\end{array}$ & $\begin{array}{c}\text { endogenous, } \\
\text { g/d }\end{array}$ & $\begin{array}{l}\text { maternal, } \\
\mathrm{g} / \mathrm{d}\end{array}$ & $\begin{array}{l}\text { foetal, } \\
\text { g/d }\end{array}$ & $\begin{array}{l}\text { total, } \\
\mathrm{g} / \mathrm{d}\end{array}$ & $\begin{array}{l}\text { total, } \\
\text { g/EW }\end{array}$ & $\begin{array}{c}g / g \\
\text { STTD-P }\end{array}$ & $\begin{array}{l}\mathrm{Ca} \\
\mathrm{g} / \mathrm{d}\end{array}$ & $\begin{array}{c}\mathrm{Ca}, \\
\mathrm{g} / \mathrm{EW}\end{array}$ & $\begin{array}{l}\mathrm{Ca}, \mathrm{g} / \mathrm{g} \\
\text { STTD-P }\end{array}$ \\
\hline 0 & 205 & 2.42 & 1.44 & 0.89 & 0.00 & 2.33 & 0.96 & 2.05 & 1.23 & 0.00 & 3.28 & 1.36 & 1.41 & 6.57 & 2.72 & 2.82 \\
\hline 7 & 207 & 2.45 & 1.45 & 0.89 & 0.00 & 2.35 & 0.96 & 2.07 & 1.23 & 0.00 & 3.31 & 1.35 & 1.41 & 6.61 & 2.70 & 2.82 \\
\hline 14 & 209 & 2.47 & 1.47 & 0.89 & 0.00 & 2.36 & 0.96 & 2.09 & 1.23 & 0.01 & 3.33 & 1.35 & 1.41 & 6.66 & 2.70 & 2.82 \\
\hline 21 & 212 & 2.48 & 1.48 & 0.90 & 0.00 & 2.38 & 0.96 & 2.12 & 1.23 & 0.01 & 3.36 & 1.35 & 1.41 & 6.72 & 2.70 & 2.82 \\
\hline 28 & 214 & 2.51 & 1.50 & 0.90 & 0.01 & 2.41 & 0.96 & 2.14 & 1.23 & 0.02 & 3.40 & 1.35 & 1.41 & 6.79 & 2.71 & 2.82 \\
\hline 35 & 218 & 2.55 & 1.52 & 0.90 & 0.05 & 2.47 & 0.97 & 2.18 & 1.23 & 0.05 & 3.46 & 1.36 & 1.40 & 6.92 & 2.72 & 2.80 \\
\hline 42 & 222 & 2.60 & 1.55 & 0.90 & 0.13 & 2.58 & 0.99 & 2.22 & 1.23 & 0.13 & 3.58 & 1.38 & 1.39 & 7.17 & 2.75 & 2.77 \\
\hline 49 & 227 & 2.66 & 1.59 & 0.91 & 0.26 & 2.76 & 1.04 & 2.27 & 1.23 & 0.29 & 3.79 & 1.43 & 1.37 & 7.59 & 2.85 & 2.75 \\
\hline 56 & 233 & 2.72 & 1.63 & 0.92 & 0.47 & 3.02 & 1.11 & 2.33 & 1.23 & 0.59 & 4.15 & 1.52 & 1.38 & 8.30 & 3.05 & 2.75 \\
\hline 63 & 239 & 2.79 & 1.68 & 0.93 & 0.77 & 3.37 & 1.21 & 2.39 & 1.23 & 1.07 & 4.70 & 1.68 & 1.39 & 9.40 & 3.37 & 2.78 \\
\hline 70 & 246 & 2.86 & 1.72 & 0.95 & 1.16 & 3.83 & 1.34 & 2.46 & 1.23 & 1.75 & 5.44 & 1.90 & 1.42 & 10.88 & 3.81 & 2.84 \\
\hline 77 & 252 & 2.93 & 1.76 & 0.96 & 1.61 & 4.34 & 1.48 & 2.52 & 1.23 & 2.58 & 6.33 & 2.16 & 1.46 & 12.67 & 4.32 & 2.92 \\
\hline 84 & 257 & 3.01 & 1.80 & 0.98 & 2.09 & 4.87 & 1.62 & 2.57 & 1.24 & 3.49 & 7.29 & 2.43 & 1.50 & 14.59 & 4.85 & 3.00 \\
\hline 91 & 261 & 3.08 & 1.83 & 1.01 & 2.55 & 5.38 & 1.75 & 2.61 & 1.24 & 4.40 & 8.25 & 2.68 & 1.53 & 16.50 & 5.35 & 3.07 \\
\hline 98 & 265 & 3.16 & 1.85 & 1.03 & 2.96 & 5.84 & 1.85 & 2.65 & 1.24 & 5.26 & 9.14 & 2.90 & 1.57 & 18.28 & 5.79 & 3.13 \\
\hline 105 & 268 & 3.24 & 1.88 & 1.05 & 3.31 & 6.25 & 1.93 & 2.68 & 1.24 & 6.02 & 9.94 & 3.07 & 1.59 & 19.88 & 6.14 & 3.18 \\
\hline 112 & 274 & 3.33 & 1.91 & 1.08 & 3.61 & 6.60 & 1.98 & 2.74 & 1.24 & 6.67 & 10.65 & 3.20 & 1.61 & 21.30 & 6.40 & 3.23 \\
\hline 115 & 276 & 3.38 & 1.93 & 1.09 & 3.78 & 6.81 & 2.02 & 2.76 & 1.24 & 7.08 & 11.09 & 3.28 & 1.63 & 22.18 & 6.57 & 3.26 \\
\hline mean & 234 & 2.76 & 1.64 & 0.94 & 1.03 & 3.61 & 1.27 & 2.34 & 1.23 & 1.74 & 5.32 & 1.86 & 1.45 & 10.63 & 3.73 & 2.89 \\
\hline
\end{tabular}

1) Total calcium adopting a standardised digestibility of $50 \%$. 
Parity 5

Factorial estimation of standardised digestible phosphorus (STTD-P) and calcium (STTD-P) requirements in gestating sows to replace faecal and urinary endogenous losses, and for retention in maternal and foetal tissues, expressed per day and per EW.

\begin{tabular}{|c|c|c|c|c|c|c|c|c|c|c|c|c|c|c|c|c|}
\hline \multirow[b]{2}{*}{ Day } & \multirow[b]{2}{*}{$\begin{array}{c}\mathrm{BW}, \\
\mathrm{kg}\end{array}$} & \multirow[b]{2}{*}{$\begin{array}{l}\text { Feed, } \\
\text { EW/d }\end{array}$} & \multicolumn{5}{|c|}{ STTD-P requirements } & \multicolumn{6}{|c|}{ STTD-Ca requirements } & \multicolumn{3}{|c|}{ Total $\mathrm{Ca}^{1)}$} \\
\hline & & & $\begin{array}{c}\text { endogenous, } \\
\mathrm{g} / \mathrm{d}\end{array}$ & $\begin{array}{l}\text { maternal, } \\
\mathrm{g} / \mathrm{d}\end{array}$ & $\begin{array}{c}\text { foetal, } \\
\text { g/d }\end{array}$ & $\begin{array}{l}\text { total, } \\
\mathrm{g} / \mathrm{d}\end{array}$ & $\begin{array}{l}\text { total, } \\
\text { g/EW }\end{array}$ & $\begin{array}{c}\text { endogenous, } \\
\mathrm{g} / \mathrm{d}\end{array}$ & $\begin{array}{l}\text { maternal, } \\
\mathrm{g} / \mathrm{d}\end{array}$ & $\begin{array}{c}\text { foetal, } \\
\mathrm{g} / \mathrm{d}\end{array}$ & $\begin{array}{l}\text { total, } \\
\mathrm{g} / \mathrm{d}\end{array}$ & $\begin{array}{l}\text { total, } \\
\text { g/EW }\end{array}$ & $\begin{array}{c}g / g \\
\text { STTD-P }\end{array}$ & $\begin{array}{l}\mathrm{Ca} \\
\mathrm{g} / \mathrm{d}\end{array}$ & $\begin{array}{c}\mathrm{Ca}, \\
\mathrm{g} / \mathrm{EW}\end{array}$ & $\begin{array}{l}\text { Ca, g/g } \\
\text { STTD-P }\end{array}$ \\
\hline$\overline{0}$ & 220 & 2.48 & 1.54 & 0.66 & 0.00 & 2.20 & 0.89 & 2.20 & 0.82 & 0.00 & 3.03 & 1.22 & 1.37 & 6.06 & 2.4 & 2.75 \\
\hline 7 & 222 & 2.51 & 1.55 & 0.66 & 0.00 & 2.22 & 0.88 & 2.22 & 0.82 & 0.00 & 3.05 & 1.21 & 1.37 & 6.09 & 2.4 & 2.75 \\
\hline 14 & 224 & 2.52 & 1.57 & 0.66 & 0.00 & 2.23 & 0.88 & 2.24 & 0.82 & 0.01 & 3.07 & 1.22 & 1.38 & 6.14 & 2.4 & 2.75 \\
\hline 21 & 226 & 2.54 & 1.58 & 0.66 & 0.00 & 2.25 & 0.88 & 2.26 & 0.82 & 0.01 & 3.09 & 1.22 & 1.38 & 6.19 & 2.4 & 2.75 \\
\hline 28 & 228 & 2.56 & 1.60 & 0.66 & 0.01 & 2.28 & 0.89 & 2.28 & 0.82 & 0.02 & 3.13 & 1.22 & 1.38 & 6.26 & 2.4 & 2.75 \\
\hline 35 & 231 & 2.60 & 1.62 & 0.67 & 0.05 & 2.34 & 0.90 & 2.31 & 0.82 & 0.05 & 3.19 & 1.23 & 1.37 & 6.38 & 2.5 & 2.73 \\
\hline 42 & 235 & 2.65 & 1.65 & 0.67 & 0.13 & 2.44 & 0.92 & 2.35 & 0.83 & 0.13 & 3.31 & 1.25 & 1.35 & 6.62 & 2.5 & 2.71 \\
\hline 49 & 240 & 2.71 & 1.68 & 0.68 & 0.26 & 2.62 & 0.97 & 2.40 & 0.83 & 0.29 & 3.52 & 1.30 & 1.34 & 7.03 & 2.6 & 2.69 \\
\hline 56 & 246 & 2.77 & 1.72 & 0.69 & 0.47 & 2.87 & 1.04 & 2.46 & 0.83 & 0.59 & 3.87 & 1.40 & 1.35 & 7.74 & 2.8 & 2.69 \\
\hline 63 & 252 & 2.83 & 1.76 & 0.70 & 0.77 & 3.23 & 1.14 & 2.52 & 0.83 & 1.07 & 4.41 & 1.56 & 1.37 & 8.83 & 3.1 & 2.73 \\
\hline 70 & 258 & 2.90 & 1.80 & 0.71 & 1.16 & 3.68 & 1.27 & 2.58 & 0.83 & 1.75 & 5.16 & 1.78 & 1.40 & 10.31 & 3.6 & 2.80 \\
\hline 77 & 263 & 2.97 & 1.84 & 0.73 & 1.61 & 4.19 & 1.41 & 2.63 & 0.83 & 2.58 & 6.04 & 2.04 & 1.44 & 12.09 & 4.1 & 2.89 \\
\hline 84 & 268 & 3.04 & 1.88 & 0.75 & 2.09 & 4.72 & 1.55 & 2.68 & 0.83 & 3.49 & 7.00 & 2.30 & 1.48 & 14.00 & 4.6 & 2.97 \\
\hline 91 & 272 & 3.11 & 1.90 & 0.77 & 2.55 & 5.22 & 1.68 & 2.72 & 0.83 & 4.40 & 7.95 & 2.56 & 1.52 & 15.91 & 5.1 & 3.04 \\
\hline 98 & 275 & 3.19 & 1.93 & 0.80 & 2.96 & 5.68 & 1.78 & 2.75 & 0.83 & 5.26 & 8.84 & 2.78 & 1.56 & 17.69 & 5.6 & 3.11 \\
\hline 105 & 279 & 3.26 & 1.95 & 0.82 & 3.31 & 6.09 & 1.86 & 2.79 & 0.84 & 6.02 & 9.64 & 2.95 & 1.58 & 19.28 & 5.9 & 3.17 \\
\hline 112 & 284 & 3.35 & 1.99 & 0.85 & 3.61 & 6.44 & 1.92 & 2.84 & 0.84 & 6.67 & 10.35 & 3.09 & 1.61 & 20.69 & 6.2 & 3.22 \\
\hline 115 & 286 & 3.40 & 2.00 & 0.86 & 3.78 & 6.65 & 1.95 & 2.86 & 0.84 & 7.08 & 10.79 & 3.17 & 1.62 & 21.57 & 6.3 & 3.24 \\
\hline mean & 247 & 2.80 & 1.73 & 0.71 & 1.03 & 3.47 & 1.20 & 2.47 & 0.83 & 1.74 & 5.04 & 1.74 & 1.42 & 10.07 & 3.5 & 2.84 \\
\hline
\end{tabular}

1) Total calcium adopting a standardised digestibility of $50 \%$. 


\section{Annex 15 Body composition of pigs at weaning}

References and characteristics of studies used to calculate calcium and phosphorus content in newly weaned pigs

\begin{tabular}{lccccc}
\hline Reference & Year & Pigs, $\mathrm{n}$ & BW, kg & $\begin{array}{c}\text { Ca, g/kg } \\
\text { BW }\end{array}$ & P, g/kg BW \\
\hline Walz and Pallauf & 1991 & 8 & 5.3 & 10.3 & 5.3 \\
Bikker et al. & 2017 & 11 & 6.3 & 6.4 & 5.0 \\
Everts and Dekker & 1991 & 16 & 7.6 & 7.5 & 4.9 \\
Jongbloed et al. & 2002 & 6 & 7.0 & 8.4 & 6.0 \\
Shields et al. & 1983 & 8 & 8.5 & 10.9 & 6.7 \\
Jongbloed et al. & 2002 & 6 & 9.2 & 8.1 & 5.6 \\
Schöne et al. & 1995 & 4 & 10.4 & 9.4 & 6.1 \\
& & & & & \\
Mean & & & 7.75 & 8.71 & 5.66 \\
Standard deviation & & & 1.74 & 1.58 & 0.63 \\
\hline
\end{tabular}




\section{Annex 16 Milk composition}

References and characteristics of studies used to calculate calcium and phosphorus content in milk

\begin{tabular}{lccccc}
\hline Reference & Year & Sows, $\mathrm{n}$ & $\begin{array}{c}\text { Day in } \\
\text { lactation }\end{array}$ & $\mathrm{Ca}, \mathrm{g} / \mathrm{kg}$ & $\mathrm{P}, \mathrm{g} / \mathrm{kg}$ \\
\hline Hill et al. & 1983 & 76 & 4 & 1.93 & 1.43 \\
Csapo et al. & 1996 & 30 & 5 & 1.63 & 1.24 \\
Maxson and Mahan & 1986 & 108 & 7 & 2.04 & 1.43 \\
Migdal & 1993 & 6 & 7 & 2.21 & 1.69 \\
Csapo et al. & 1996 & 30 & 10 & 1.66 & 1.20 \\
Hill et al. & 1983 & 72 & 11 & 2.10 & 1.48 \\
Seynave et al. & 1996 & 30 & 13 & 1.55 & 1.39 \\
Mahan et al. & 1982 & 36 & 14 & 1.97 & 1.47 \\
Renaudeau et al. & 2003 & 6 & 16 & 2.60 & 1.55 \\
Giesemann et al. & 1998 & 19 & 17 & 2.07 & 1.57 \\
Hill et al. & 1983 & 71 & 17 & 2.23 & 1.55 \\
Peters et al. & 2010 & 63 & 17 & 1.95 & 1.47 \\
Bikker et al. & 2017 & 11 & 20 & 2.03 & 1.48 \\
Csapo et al. & 1996 & 30 & 20 & 1.75 & 1.32 \\
Beyga and Rekiel & 2009 & 34 & 21 & 1.94 & 1.34 \\
Lyberg et al. & 2007 & 48 & 21 & 1.87 & 1.40 \\
Maxson and Mahan & 1986 & 108 & 21 & 2.24 & 1.58 \\
Seynave et al. & 1996 & 30 & 27 & 1.89 & 1.55 \\
Mahan et al. & 1982 & 36 & 28 & 2.30 & 1.67 \\
& & & & & \\
Mean & & & & 2.00 & 1.46 \\
Standard deviation & & & &
\end{tabular}




\section{Annex 17 Weekly $\mathrm{P}$ and $\mathrm{Ca}$ requirements of a first parity sow in lactation.}

Calculated requirements of a $1^{\text {st }}$ parity sow with 14 suckling piglets, a litter gain of $2.5 \mathrm{~kg} / \mathrm{d}$, with tissue mobilisation according to assumptions in Annex 13.

\begin{tabular}{|c|c|c|c|c|c|}
\hline Lactation week & 1 & 2 & 3 & 4 & mean \\
\hline \multicolumn{6}{|l|}{ Energy metabolism ${ }^{1}$} \\
\hline Body weight gain per piglet, kg/d & 0.143 & 0.188 & 0.196 & 0.188 & 0.179 \\
\hline Mean BW piglet, kg & 1.75 & 2.91 & 4.25 & 5.59 & 3.63 \\
\hline Protein deposition per piglet, $\mathrm{g} / \mathrm{d}$ & 22.9 & 30.0 & 31.4 & 30.0 & 28.6 \\
\hline Lipid deposition per piglet, $\mathrm{g} / \mathrm{d}$ & 22.1 & 30.2 & 31.9 & 30.2 & 28.6 \\
\hline Energy requirements per piglet, $\mathrm{kJ} \mathrm{NE} / \mathrm{d}$ & 1819 & 2446 & 2575 & 2446 & 2322 \\
\hline Required energy in milk, $\mathrm{MJ} / \mathrm{d}$ & 37.5 & 51.6 & 58.4 & 60.9 & 52.1 \\
\hline Milk production based on energy, $\mathrm{kg} / \mathrm{d}$ & 7.5 & 10.3 & 11.7 & 12.2 & 10.4 \\
\hline Mean body weight sow, $\mathrm{kg}$ & 192.2 & 186.6 & 180.9 & 175.3 & 183.8 \\
\hline Energy requirements sow, EW/d & 5.97 & 7.54 & 8.29 & 8.57 & 7.59 \\
\hline Energy mobilisation, based on defined BW loss, MJ NE/d & 16.82 & 16.82 & 16.82 & 16.82 & 16.82 \\
\hline Energy requirements sow after mobilisation, EW/d & 4.32 & 5.84 & 6.55 & 6.79 & 5.87 \\
\hline Energy from mobilised tissue, EW/d & 1.66 & 1.70 & 1.74 & 1.78 & 1.72 \\
\hline P maintenance sow, g/d & 1.92 & 1.87 & 1.81 & 1.75 & 1.84 \\
\hline$P$ based on ret. piglets, $g / d$ & 12.06 & 15.89 & 16.76 & 16.15 & 15.21 \\
\hline$P$ in milk, $g / d$ & 10.94 & 15.06 & 17.05 & 17.79 & 15.21 \\
\hline P from mobilised body tissue, $\mathrm{g} / \mathrm{d}$ & 0.87 & 0.87 & 0.87 & 0.87 & 0.87 \\
\hline STTD-P requirement in total, $\mathrm{g} / \mathrm{d}$ & 13.36 & 17.21 & 18.04 & 17.37 & 16.49 \\
\hline \multirow[t]{2}{*}{ Ca maintenance sow, g/d } & 2.69 & 2.61 & 2.53 & 2.45 & 2.57 \\
\hline & 17.96 & 23.66 & 24.96 & 24.04 & 22.65 \\
\hline $\mathrm{Ca}$ in milk, $\mathrm{g} / \mathrm{d}$ & 14.98 & 20.63 & 23.35 & 24.37 & 20.83 \\
\hline Ca from mobilised body tissue, $\mathrm{g} / \mathrm{d}$ & 0.06 & 0.06 & 0.06 & 0.06 & 0.06 \\
\hline STTD-Ca requirement in total, $\mathrm{g} / \mathrm{d}$ & 18.46 & 24.33 & 27.11 & 28.11 & 24.50 \\
\hline STTD-P requirement, g/EW & 2.83 & 2.80 & 2.80 & 2.80 & 2.81 \\
\hline STTD-Ca requirement, g/EW & 4.28 & 4.17 & 4.14 & 4.14 & 4.17 \\
\hline STTD-P/STTD-Ca & 1.51 & 1.49 & 1.48 & 1.48 & 1.49 \\
\hline Ca requirement, assuming $50 \%$ dig. Ca & 36.92 & 48.65 & 54.22 & 56.21 & 49.00 \\
\hline Ca requirement, g/EW & 8.55 & 8.33 & 8.28 & 8.28 & 8.34 \\
\hline Ca/STTD-P & 3.02 & 2.97 & 2.96 & 2.95 & 2.97 \\
\hline
\end{tabular}

${ }^{1}$ Energy metabolism based on Everts et al. (1995) 


\section{Annex $18 \mathrm{P}$ and $\mathrm{Ca}$ requirements in lactation in relation to parity.}

Calculated requirements of parity 1 to 5 sows with 14 suckling piglets, a litter gain of 2.5 and $3.0 \mathrm{~kg} / \mathrm{d}$ for primiparous and multiparous sows, with tissue mobilisation according to assumptions in Annex 13.

\begin{tabular}{lrrrrr}
\hline Parity & 1 & 2 & 3 & 4 & 5 \\
\hline Energy metabolism ${ }^{1}$ & & & & & \\
Initial body weight sow, kg & 195 & 215 & 230 & 245 & 255 \\
Energy requirements sow, EW/d & 7.59 & 8.84 & 8.94 & 9.04 & 9.10 \\
Energy from mobilised tissue, EW/d & 1.72 & 1.48 & 1.32 & 1.32 & 1.16 \\
Energy requirements sow after mobilisation, EW/d & 5.87 & 7.36 & 7.62 & 7.72 & 7.94 \\
& & & & & \\
& & & & \\
P maintenance sow, g/d & 1.84 & 2.04 & 2.21 & 2.36 & 2.49 \\
P based on ret. piglets, g/d & 15.2 & 18.2 & 18.2 & 18.2 & 18.2 \\
P in milk, g/d & 15.2 & 18.1 & 18.1 & 18.1 & 18.1 \\
P from mobilised body tissue, g/d & 0.87 & 0.97 & 0.68 & 0.68 & 0.39 \\
STTD-P requirement in total, g/d & 16.5 & 19.6 & 20.0 & 20.2 & 20.6 \\
& & & & & \\
Ca maintenance sow, g/d & 2.57 & 2.85 & 3.10 & 3.31 & 3.48 \\
Ca in milk, g/d & 20.8 & 24.8 & 24.8 & 24.8 & 24.8 \\
Ca from mobilised body tissue, g/d & 0.06 & 0.06 & 0.05 & 0.05 & 0.03 \\
STTD-Ca requirement in total, g/d & 24.5 & 29.0 & 29.2 & 29.4 & 29.6 \\
& & & & & \\
STTD-P requirement, g/EW & 2.81 & 2.66 & 2.63 & 2.61 & 2.59 \\
STTD-Ca requirement, g/EW & 4.17 & 3.94 & 3.84 & 3.81 & 3.73 \\
STTD-P/STTD-Ca & 1.49 & 1.48 & 1.46 & 1.46 & 1.44 \\
Ca requirement, assuming 50\% dig. Ca & & & & & \\
Ca requirement, g/EW & 49.0 & 58.0 & 58.5 & 58.9 & 59.2 \\
Ca/STTD-P & 8.34 & 7.88 & 7.67 & 7.63 & 7.46 \\
1 Energy metabolism based on Everts et al.(1995) & & & & & \\
\hline
\end{tabular}

${ }^{1}$ Energy metabolism based on Everts et al. (1995) 